\title{
De inpassing van schoolverlatersinformatie in het ROA-informatiesysteem onderwijs-arbeidsmarkt
}

Citation for published version (APA):

de Grip, A., van der Velden, R. K. W., \& Wieling, M. (1993). De inpassing van schoolverlatersinformatie in het ROA-informatiesysteem onderwijs-arbeidsmarkt. Researchcentrum voor Onderwijs en Arbeidsmarkt, Faculteit der Economische Wetenschappen. ROA Reports No. 9

https://doi.org/10.26481/umarep.1993009

Document status and date:

Published: 01/01/1993

DOI:

10.26481/umarep.1993009

Document Version:

Publisher's PDF, also known as Version of record

\section{Please check the document version of this publication:}

- A submitted manuscript is the version of the article upon submission and before peer-review. There can be important differences between the submitted version and the official published version of record.

People interested in the research are advised to contact the author for the final version of the publication, or visit the DOI to the publisher's website.

- The final author version and the galley proof are versions of the publication after peer review.

- The final published version features the final layout of the paper including the volume, issue and page numbers.

Link to publication

\footnotetext{
General rights rights.

- You may freely distribute the URL identifying the publication in the public portal. please follow below link for the End User Agreement:

www.umlib.nl/taverne-license

Take down policy

If you believe that this document breaches copyright please contact us at:

repository@maastrichtuniversity.nl

providing details and we will investigate your claim.
}

Copyright and moral rights for the publications made accessible in the public portal are retained by the authors and/or other copyright owners and it is a condition of accessing publications that users recognise and abide by the legal requirements associated with these

- Users may download and print one copy of any publication from the public portal for the purpose of private study or research.

- You may not further distribute the material or use it for any profit-making activity or commercial gain

If the publication is distributed under the terms of Article $25 \mathrm{fa}$ of the Dutch Copyright Act, indicated by the "Taverne" license above, 


\title{
DE INPASSING VAN SCHOOLVERLATERSINFORMATIE IN HET ROA-INFORMATIESYSTEEM ONDERWIJS-ARBEIDSMARKT
}

ROA-R-1993/9

\author{
A. de Grip \\ R.K.W. van der Velden \\ M.H. Wieling
}

RESEARCHCENTRUM VOOR ONDERWIJS EN ARBEIDSMARKT

Faculteit der Economische Wetenschappen

Rijksuniversiteit Limburg

Maastricht, december 1993 


\section{CIP-GEGEVENS KONINKLIJKE BIBLIOTHEEK, DEN HAAG}

Grip, A. de

De inpassing van schoolverlatersinformatie in het ROA-informatiesysteem onderwijsarbeidsmarkt / A. de Grip, R.K.W. van der Velden, M.H. Wieling. - Maastricht: Researchcentrum voor Onderwijs en Arbeidsmarkt, Faculteit der Economische Wetenschappen, Rijksuniversiteit Limburg. - Tab. - ([Rapport] / Researchcentrum voor Onderwijs en Arbeidsmarkt, ISSN 09228098 ; ROA-R-1993/9)

Met lit. opg.

ISBN 90-5321-118-7

Trefw.: onderwijs en arbeidsmarkt ; informatiesystemen 


\section{INHOUDSOPGAVE}

Bladzijde

VOORWOORD

1. INLEIDING 1

2. SCHOOLVERLATERSDATA 5

2.1. Inleiding 5

2.2. De RUBS- en HBO-enquêtes 5

2.3. Inpasbaarheid schoolverlatersdata: verschilpunten 6

2.4. Inpasbaarheid schoolverlatersdata: mogelijkheden 8

3. ARBEIDSMARKTINDICATOREN VOOR SCHOOLVERLATERS 11

3.1. Inleiding 11

3.2. Actuele indicatoren 13

3.3. Risico-indicatoren 28

4. SAMENGESTELDE INDICATOREN 34

4.1. Inleiding 34

4.2. Arbeidsmarktpositie van schoolverlaters grafisch weergegeven 34

4.3. Mismatch in de directe aansluiting tussen onderwijs en arbeidsmarkt $\quad 39$

4.4. Arbeidsmarktindicatoren op individueel niveau 40

5. VOORTIJDIGE SCHOOLVERLATERS 46

5.1. Inleiding 46

5.2. Indicatoren voor voortijdige schoolverlaters 48

6. BESLUIT 55

6.1. Belangrijkste uitkomsten $\quad 55$

$\begin{array}{ll}\text { 6.2. Mogelijke vervolgtrajecten } & 57\end{array}$

$\begin{array}{ll}\text { LITERATUUR } & 63\end{array}$

BIJLAGE I: ONDERSCHEIDEN OPLEIDINGSRICHTINGEN 66

BIJLAGE II: AANVULLENDE TABELLEN 
$\cdots$ 


\section{VOORWOORD}

Het Researchcentrum voor Onderwijs en Arbeidsmarkt (ROA) heeft, in opdracht van het Ministerie van Onderwijs en Wetenschappen, het Centraal Bestuur voor de Arbeidsvoorziening (CBA) en de Stichting Landelijk Dienstverlenend Centrum voor studie- en beroepskeuzevoorlichting (LDC), het informatiesysteem onderwijs-arbeidsmarkt ontwikkeld. Binnen dit informatiesysteem is het van groot belang om in aansluiting op de arbeidsmarktinformatie die momenteel wordt gegenereerd met betrekking tot de gehele werkzame bevolking, ook een beter inzicht te geven in de directe aansluiting tussen het initiële onderwijs en de eerste bestemming van schoolverlaters op de arbeidsmarkt. De eerste bestemming op de arbeidsmarkt kan namelijk in belangrijke mate bepalend zijn voor de verdere carrièremogelijkheden. Het ROA voert twee onderzoeken uit die op landelijk en regionaal niveau representatieve informatie genereren met betrekking tot de arbeidsmarktpositie van schoolverlaters. Dit betreft de enquête Registratie Uitstroom en Bestemming van Schoolverlaters (RUBS) en de HBO-Monitor. In dit rapport wordt nagegaan in hoeverre deze schoolverlatersinformatie zou kunnen worden ingepast in het ROA informatiesysteem onderwijs-arbeidsmarkt.

Het onderzoek werd uitgevoerd door dr. A. de Grip (projectleider), dr. R.K.W. van der Velden en drs. M.H. Wieling. M.E.C. Reiners heeft assistentie verleend bij de analyse van de data. De auteurs danken de leden van de begeleidingscommissie ROA-informatiesysteem onderwijsarbeidsmarkt voor hun commentaar op de concept-versie van dit rapport. 

$\cdots$ 


\section{INLEIDING}

In opdracht van het Ministerie van Onderwijs en Wetenschappen, het Centraal Bestuur voor de Arbeidsvoorziening en het Landelijk Dienstverlenend Centrum voor studie- en beroepskeuzevoorlichting (LDC) werkt het Researchcentrum voor Onderwijs en Arbeidsmarkt (ROA) aan een informatiesysteem onderwijs-arbeidsmarkt. De gegenereerde arbeidsmarktinformatie wordt in principe jaarlijks aangeleverd aan het LDC, dat de informatie opneemt in verschillende voorlichtingsprodukten. Zo brengt het LDC het geautomatiseerde informatiesysteem Traject uit, dat vooral is bedoeld voor de intermediairs bij de studie- en beroepskeuzevoorlichting. Bovendien wordt de informatie gepubliceerd in het tweejaarlijkse ROA-rapport De arbeidsmarkt naar opleiding en beroep (zie ROA, 1992a en 1992b). Dit rapport heeft als doel informatie te verschaffen die vanuit beleidsoogpunt van belang is. De belangrijkste informatie uit dit rapport is ook gebruikt voor het door het LDC ten behoeve van de studie- en beroepskeuzevoorlichting uitgebrachte boekje Kansen op werk (LDC, 1993).

In het informatiesysteem onderwijs-arbeidsmarkt wordt tot op heden met name op landelijk niveau arbeidsmarktinformatie verstrekt, verbijzonderd naar bedrijfssector, beroepsklasse en opleidingstype. Daarbij wordt tot dusver voornamelijk uitgegaan van gegevens met betrekking tot de totale beroepsbevolking of het totaal aantal werkzame personen'. Echter, om een beter inzicht in de directe aansluiting tussen onderwijs en arbeidsmarkt te verkrijgen, is informatie over de aansluiting tussen het initiële onderwijs en de eerste bestemming van schoolverlaters op de arbeidsmarkt van zeer groot belang. De eerste bestemming op de arbeidsmarkt kan namelijk in belangrijke mate bepalend zijn voor de verdere carrièremogelijkheden.

Sinds kort is een tweetal microbestanden beschikbaar gekomen, op basis waarvan waardevolle informatie over de arbeidsmarktpositie van schoolverlaters kan worden samengesteld. Het gaat in beide gevallen om grootschalige schriftelijke enquêtes onder schoolverlaters die ongeveer een jaar na het beëindigen van de opleiding worden gehouden. Beide enquêtes beogen een periodieke jaarlijkse meting van de uitstroom en de bestemming van de schoolverlaters. De eerste enquête is gehouden in het kader van het RUBS-project (Registratie Uitstroom en Bestemming van Schoolverlaters). Het gaat hierbij om schoolverlaters uit het voltijd Algemeen Voortgezet Onderwijs (AVO) het Lager Beroepsonderwijs (LBO) en het Middelbaar Beroepsonderwijs (MBO). De tweede enquête is de HBO-Monitor, die zich richt op afgestudeerden uit het voltijd en deeltijd Hoger Beroepsonderwijs (HBO).

Het spreekt voor zich dat beide schoolverlatersenquêtes het ROA-informatiesysteem onderwijsarbeidsmarkt met relevante arbeidsmarktinformatie zouden kunnen verrijken. Dit temeer daar er bij de opzet van beide enquêtes voor gezorgd is dat de gehanteerde definities en classificaties

1. Een uitzondering vormen de werkloosheidspercentages voor schoolverlaters per ROA-opleidingstype en de prognoses van het aantal schoolverlaters dat in de nabije toekomst op de arbeidsmarkt terecht zal komen. Bovendien wordt uiteindelijk een indicatie gegeven van de verwachte arbeidsmarktperspectieven voor schoolverlaters. 
koppelbaar zijn aan de classificaties van het ROA en van het Centraal Bureau voor de Statistiek (CBS) die ten grondslag liggen aan de arbeidsmarktinformatie die tot op heden de basis vormt van het informatiesysteem onderwijs-arbeidsmarkt.

Zowel voor de RUBS- als voor de HBO-enquête geldt dat de steekproef redelijk is gespreid naar regio en opleiding. Dit maakt het mogelijk om voor alle in de enquêtes onderscheiden opleidingen betrouwbare informatie te geven. Vooralsnog is het echter niet mogelijk om voor alle opleidingen schoolverlatersinformatie te verstrekken, omdat er nog geen gegevens beschikbaar zijn over schoolverlaters van het basisonderwijs en van het wetenschappelijk onderwijs (WO) ${ }^{2}$. Dit maakt dat de RUBS- en HBO-data (nog) geen totaalbeeld opleveren op het niveau van de te onderscheiden bedrijfs- en beroepscategorieën. Het ligt derhalve voor de hand om vooralsnog alleen opleidingen als uitgangspunt te kiezen voor de inpassing van schoolverlatersinformatie in het ROA-informatiesysteem onderwijs-arbeidsmarkt. Bij de informatie die voor de verschillende opleidingen wordt gegeven, wordt echter telkens ook informatie over de voor schoolverlaters relevante bedrijfssectoren en beroepen ingepast.

\section{Probleemstelling}

In dit rapport zal verslag worden gedaan van een verkennend onderzoek naar de mogelijkheden die de resultaten van de RUBS-enquête en de HBO-Monitor bieden voor het construeren van arbeidsmarktindicatoren e.d., die kunnen worden ingepast in het informatiesysteem. De centrale vraag die aan dit verkennende onderzoek ten grondslag ligt kan als volgt worden geformuleerd:

\section{Welke mogelijkheden bieden de RUBS- en HBO-schoolverlatersenquêtes tot verbetering en uitbreiding van de huidige arbeidsmarktinformatie in het informatiesysteem onderwijs-arbeidsmarkt en welke knelpunten treden daarbij op?}

Deze probleemstelling zal worden uitgewerkt aan de hand van de volgende aandachtspunten:

- $\quad$ in hoeverre is het mogelijk en zinvol om de arbeidsmarktindicatoren die momenteel reeds een onderdeel vormen van het informatiesysteem bij voorkeur op een lager aggregatieniveau (ook) specifiek voor schoolverlaters te genereren?

- welke nieuwe indicatoren zouden op basis van de beide schoolverlatersenquêtes kunnen worden opgesteld?

- welke samengestelde indicatoren die een afgewogen beeld geven van de initiële aansluiting tussen onderwijs en arbeidsmarkt, zouden er kunnen worden opgesteld?

- $\quad$ welke eventuele knelpunten doen zich voor:

* $\quad$ in de aansluiting tussen beide schoolverlatersenquêtes;

* in de aansluiting tussen enerzijds de beide enquêtes en anderzijds de CBSgegevens die ten grondslag liggen aan de huidige inhoud van het informatiesysteem?

2. Het zou wat dit betreft zeer wenselijk zijn indien er in de toekomst informatie beschikbaar zou komen met betrekking tot de recent afgestudeerden van het WO in de vorm van een WO-scanner. 
welke conceptuele problemen van het huidige informatiesysteem zouden kunnen worden opgelost met behulp van de informatie die beschikbaar komt uit de beide schoolverlatersenquêtes?

Achtergrond bij dit verkennende onderzoek, is vanzelfsprekend de gebruikswaarde van de arbeidsmarktinformatie voor de beoogde gebruiksdoelen van het informatiesysteem onderwijsarbeidsmarkt: de studie- en beroepskeuzevoorlichting en het verstrekken van informatie ten behoeve van verschillende beleidsdoeleinden ${ }^{3}$. Centraal daarbij staat de informatie die inzicht geeft in de positie van een bepaalde opleiding op de arbeidsmarkt in het algemeen, waarbij er doorgaans geen correctie plaatsvindt voor de mogelijk relevante achtergrondkenmerken van de schoolverlaters van de desbetreffende opleiding.

In aansluiting daarop zal echter ook een aanzet worden gegeven tot het in beeld brengen van indicatoren die op individueel of groepsniveau inzicht geven in de 'netto' effecten van het volgen van een bepaalde opleiding op de arbeidsmarktkansen van schoolverlaters met bepaalde achtergrondkenmerken. Ten slotte kan ook worden gedacht aan indicatoren die op macro niveau inzicht kunnen geven in het functioneren van de arbeidsmarkt in het algemeen en de rol van de gevolgde opleiding in het selectieproces in het bijzonder. Daarbij gaat het bijvoorbeeld om indicatoren die de concurrentieverhoudingen tussen opleidingen op de arbeidsmarkt of eventuele verdringingsverschijnselen en arbeidsmarktsegmentatieprocessen in beeld brengen. Op deze laatstgenoemde soort indicatoren zal in dit rapport slechts zijdelings worden ingegaan.

De verdere opbouw van dit rapport is als volgt. Eerst zal in hoofdstuk 2 kort worden ingegaan op de opzet en achtergrond van de RUBS- en de HBO-enquêtes. Vervolgens komt de inpasbaarheid van de resultaten van beide enquêtes aan de orde. Daarbij zal ook worden ingegaan op de mogelijkheden die de beide schoolverlatersenquêtes bieden om bestaande conceptuele problemen in het informatiesysteem op te lossen.

Vervolgens zal in hoofdstuk 3 een overzicht worden gegeven van de verschillende arbeidsmarktindicatoren die op basis van de RUBS- en HBO-enquêtes zouden kunnen worden opgesteld. Daarbij wordt een onderscheid gemaakt tussen bestaande indicatoren die nu specifiek voor schoolverlaters kunnen worden opgesteld en indicatoren die een belangrijke aanvulling op de huidige inhoud van het informatiesysteem zouden kunnen geven. Ter illustratie zullen de verschillende indicatoren ook daadwerkelijk worden gepresenteerd voor de verschillende technische opleidingsrichtingen binnen het $\mathrm{LBO}, \mathrm{KMBO}, \mathrm{MBO}$ en het $\mathrm{HBO}$.

Daarna wordt in hoofdstuk 4 getracht om samengestelde indicatoren op te stellen die een afgewogen beeld geven van de initiële aansluiting tussen onderwijs en arbeidsmarkt, achtereenvolgens toegespitst op de 'mismatch' in de directe aansluiting tussen onderwijs en

3. Inmiddels wordt de laatste hand gelegd aan een nieuwe versie van het rapport De arbeidsmarkt naar opleiding en beroep tot 1998 (zie ook ROA, 1993a en 1993b). In het themadeel van dit rapport wordt de arbeidsmarktsituatie van recent afgestudeerden van het $\mathrm{HBO}$ belicht. 
arbeidsmarkt en de typering van de eventuele arbeidsmarktrisico's die bepaalde opleidingsrichtingen met zich meebrengen. Ook in dit hoofdstuk zal de gepresenteerde informatie worden toegespitst op de bovengenoemde technische opleidingsrichtingen.

In hoofdstuk 5 wordt nader ingegaan op de arbeidsmarktinformatie die op basis van de beide schoolverlatersenquêtes kan worden gegenereerd met betrekking tot de voortijdige schoolverlaters. Ter illustratie worden indicatoren gepresenteerd met betrekking tot de ongediplomeerde schoolverlaters van het technisch onderwijs op LBO- en MBO-niveau.

Ten slotte worden in hoofdstuk 6 de belangrijkste uitkomsten van dit verkennende onderzoek kort samengevat. Daarbij zal ook worden ingegaan op de wenselijkheid van eventuele verdere ontwikkelprojecten met betrekking tot de integratie van schoolverlatersinformatie in het informatiesysteem onderwijs-arbeidsmarkt. 


\section{SCHOOLVERLATERSDATA}

\subsection{Inleiding}

In dit hoofdstuk wordt ingegaan op de inpasbaarheid en mogelijkheden van de schoolverlatersdata in het informatiesysteem onderwijs-arbeidsmarkt. Daarbij is uitgegaan van de opzet en inhoud van de RUBS-enquête die in het voorjaar van 1992 is gehouden en de HBO-Monitor van eind 1991/begin 1992. Eerst wordt in paragraaf 2.2 de opzet en achtergrond van het RUBSproject en de HBO-Monitor geschetst. Vervolgens komt in paragraaf 2.3 de inpasbaarheid van de resultaten van beide enquêtes aan de orde. Daarbij zal ook worden ingegaan op de mogelijkheden die de beide schoolverlatersenquêtes bieden om bestaande conceptuele problemen in het informatiesysteem op te lossen.

\subsection{De RUBS- en HBO-enquêtes}

Enkele jaren geleden is het initiatief genomen tot het RUBS-project. Het RUBS-onderzoek is een grootschalig onderzoek waarmee een periodiek herhaalde registratie van de uitstroom en bestemming van gediplomeerde en voortijdige schoolverlaters uit het voltijd onderwijs wordt beoogd. De landelijke financiering is hierbij afkomstig van het Ministerie van Onderwijs en Wetenschappen, het Ministerie van Landbouw, Natuurbeheer en Visserij, het Centraal Bestuur voor de Arbeidsvoorziening (CBA) en het LDC. Regionale financiering is vooral afkomstig van Regionale Besturen voor de Arbeidsvoorziening (RBA's), de provincies en enkele grote gemeenten. Het onderzoek bestaat uit een schriftelijke enquête onder gediplomeerde en voortijdige schoolverlaters van het AVO, LBO en MBO, een klein jaar na het beëindigen van de opleiding. Het doel van deze enquête is het achterhalen van de 'eerste bestemming' van de schoolverlaters, waardoor een actueel beeld wordt verkregen van de positie van de schoolverlaters op de arbeidsmarkt en de aansluiting tussen onderwijs en arbeidsmarkt voor bepaalde opleidingscategorieën. Bovendien wordt meer inzicht verkregen in de bestemming in het vervolgonderwijs.

Bij het RUBS-project van 1992 is voor het eerst een landelijke steekproef gerealiseerd over de volle breedte van het $\mathrm{AVO}$, $\mathrm{LBO}$ en $\mathrm{MBO}^{4}$. Het ROA heeft hierbij de landelijke projectleiding. In totaal zijn in het voorjaar van 1992 ongeveer 80.000 gediplomeerde en voortijdige schoolverlaters benaderd, verspreid over vijftien zogenaamde opleidingsclusters. Het gaat daarbij om schoolverlaters die in het schooljaar 1990/1991 een opleiding in het voortgezet onderwijs hebben verlaten. Binnen het AVO wordt een drietal clusters onderscheiden, namelijk

4. Voor de verslagen van deze enquête wordt verwezen naar Wieling, Van de Loo en Van der Velden (1993a en 1993b). Recent zijn ook de gegevens over de meting in het voorjaar van 1993 ter beschikking gekomen. 
het MAVO, HAVO en VWO. Daarnaast wordt het $\mathrm{LBO}^{5}$, het $\mathrm{MBO}$ en het kort middelbaar beroepsonderwijs (KMBO) onderverdeeld in telkens vier opleidingsclusters, namelijk agrarisch, technisch, economisch-administratief en verzorgend. De respons bedroeg ongeveer $55 \%$, zodat voor ruim 44.000 schoolverlaters informatie is verkregen over de bestemming ongeveer een jaar na het verlaten van de opleiding en de aansluiting tussen de gevolgde opleiding en de bezigheden van de schoolverlaters op het moment van enquêteren ${ }^{6}$.

In het voorjaar van 1990 heeft de HBO-Raad het ROA opdracht gegeven om een instrument te ontwikkelen waarmee afgestudeerden van het HBO kunnen worden gevolgd. De hiervoor ontwikkelde HBO-Monitor, bestaat uit twee meetinstrumenten. Ruim één jaar na het verlaten van de opleiding krijgt de afgestudeerde een zogeheten basisvragenlijst toegestuurd. Deze basisvragenlijst genereert een breed scala aan informatie over de startfuncties van de afgestudeerden. De op deze wijze verkregen informatie kan in beginsel jaarlijks worden geactualiseerd met behulp van de zogeheten 'jaarkaart'. Hierin wordt de arbeidsmarktloopbaan van het achterliggende jaar in kaart gebracht en worden opnieuw vragen gesteld over de uitgeoefende functie, het bedrijf waar men werkzaam is en de eventuele vervolgopleidingen die men volgt.

De onderzoeksgroep van de HBO-Monitor bestaat in beginsel uit diegenen die een getuigschrift hebben gehaald bij één van de initiële eerste fase opleidingen van het HBO. Elke hogeschool kan met én of meer sectoren in het project participeren. Wat betreft de HBO-Monitor gegevens is gebruik gemaakt van de meting in het eerste uitvoeringsjaar $1991^{7}$. Destijds participeerden 46 hogescholen in het project, met in totaal 16.000 afgestudeerden. Dit betekent dat de HBOMonitor 1991 ongeveer de helft van de totale toenmalige uitstroom aan afgestudeerden van het HBO dekt ${ }^{8}$. Het gaat daarbij om afgestudeerden die in het schooljaar 1989/1990 een opleiding in het hoger beroepsonderwijs hebben voltooid. De respons bedraagt ongeveer $62 \%$, zodat voor bijna 10.000 afgestudeerden informatie is verkregen over de bestemming ruim een jaar na het verlaten van de opleiding.

\subsection{Inpasbaarheid schoolverlatersdata: verschilpunten}

De gegevens over de werkende beroepsbevolking in het Informatiesysteem Onderwijs-Arbeid

5. Per 1 augustus 1992 is het LBO veranderd in het Voorbereidend Beroepsonderwijs (VBO). Aangezien het hier echter gaat om schoolverlaters die voor deze datum de opleiding hebben verlaten, wordt in dit rapport nog gesproken van het LBO.

6. In 1993 zijn in totaal zo'n 47.000 schoolverlaters van het AVO, LBO en MBO benaderd, waarvan uiteindelijk circa 28.000 schoolverlaters aan de enquête hebben deelgenomen.

7. Voor een verslag van deze meting wordt verwezen naar de zes sectorrapporten die hierover zijn uitgebracht (Van de Loo, Ramaekers en Van der Velden, 1992a tot en met 1992f). Recent zijn ook de gegevens over de meting in het najaar van 1992 gepubliceerd (Van de Loo, Van der Velden en Wieling, 1993).

8. In het uitvoeringsjaar 1992 is de deelname van hogescholen gestegen tot 55 met in totaal zo'n 20.000 afgestudeerden. Inmiddels is de dekkingsgraad verder toegenomen. Bij de meting van 1993 participeert tweederde van de hogescholen met in totaal zo'n 23.000 afgestudeerden. 
worden op dit moment ontleend aan de Enquête Beroepsbevolking (EBB) van het CBS. De gegevens van de schoolverlatersenquêtes wijken hier in aantal opzichten vanaf, te weten:

- steekproefpopulatie;

- steekproefdesign;

- onderzoeksmethode;

- dataverzameling.

Hieronder zal achtereenvolgens kort op deze vier verschilpunten worden ingegaan.

\section{Steekproefpopulatie:}

De EBB heeft betrekking op huishoudens en daarmee op de gehele beroepsbevolking c.q. werkzame bevolking. De RUBS-enquête heeft daarentegen louter betrekking op (gediplomeerde en ongediplomeerde) schoolverlaters uit het AVO, LBO en MBO. De HBO-Monitor heeft betrekking op de recent afgestudeerden van de initiële, door het Ministerie van Onderwijs en Wetenschappen bekostigde, studierichtingen van het HBO.

\section{Steekproefdesign:}

De EBB betreft een aselecte steekproef van huishoudens, waarbij via de respondent arbeidsmarktinformatie wordt verzameld van elk gezinslid van 15 jaar en ouder (CBS, 1993a). Bij RUBS is sprake van een clustersteekproef van scholen uit het voortgezet onderwijs, waarbij alle schoolverlaters die tot de populatie behoren in de steekproef worden opgenomen. De steekproef is gestratificeerd naar opleiding en regio, waarbij in sommige regio's aanvullende metingen hebben plaatsgevonden. Het bestand is herwogen naar landelijke representatieve aantallen. Bij de HBO-Monitor is geen sprake van een steekproef. De instellingen voor hoger onderwijs participeren op vrijwillige basis. Door de hoge dekkingsgraad en het feit dat de deelname redelijk gespreid is over het land, kan het bestand echter als representatief beschouwd worden voor de onderzochte populatie.

\section{Onderzoeksmethode:}

Bij de EBB is sprake van face-to-face interviews met behulp van schootcomputers (CBS, 1993a), terwijl bij de schoolverlatersonderzoeken sprake is van schriftelijke vragenlijsten.

\section{Dataverzameling:}

Bij de EBB is sprake van een doorlopende dataverzameling, waarbij min of meer continu maandelijks ruim 10.000 huishoudens worden benaderd (CBS, 1993a). Bij RUBS is sprake van een benadering in de periode maart-juni, ruim drie-kwart jaar na het verlaten van de opleiding. De vragenlijsten worden door de scholen zelf verstuurd naar het bij hen laatst bekende adres van de schoolverlaters. Na enkele weken volgt, indien nodig, een rappel. Bij de HBO-Monitor worden de afgestudeerden benaderd in de periode oktober-januari, gemiddeld anderhalf jaar na 
afstuderen. De vragenlijsten worden hetzij door de instellingen voor hoger onderwijs zelf verzonden, hetzij via het Servicebureau Schoolverlatersinformatie. Indien nodig volgt na enkele weken een rappel. De eerste mailing is gericht aan het laatste bekende studie-adres, de tweede mailing aan het ouderlijk adres (voor zover bekend).

\subsection{Inpasbaarheid schoolverlatersdata: mogelijkheden}

Het inpassen van de RUBS- en HBO-schoolverlatersbestanden in het informatiesysteem onderwijs-arbeidsmarkt van het ROA biedt in potentie een aantal perspectieven. Door het verstrekken van informatie over de arbeidsmarktsituatie van schoolverlaters wordt inzicht verkregen in de directe aans/uiting tussen het initiële onderwijs en de eerste bestemming op de arbeidsmarkt. Er dient daarbij wel een afweging te worden gemaakt of de schoolverlatersgegevens als additionele informatie worden gepresenteerd, naast de informatie die momenteel per ROA-beroepsklasse en opleidingstype wordt gegeven ${ }^{9}$, dan wel of de schoolverlatersinformatie in plaats van de huidige arbeidsmarktinformatie wordt gegeven.

Door het vergelijken van de arbeidsmarktgegevens van werkzame personen met de schoolverlatersinformatie wordt inzicht verkregen in de verschillen tussen de arbeidsmarktsituatie van schoolverlaters en die van de totale beroepsbevolking met de desbetreffende opleidingsachtergrond. Op basis hiervan is het wellicht mogelijk om (trendmatige) verschuivingen in de arbeidsmarktsituatie van een bepaalde opleidingscategorie te signaleren. Daarbij kan worden gedacht aan de ontwikkeling van het belang van bepaalde bedrijfssectoren of beroepen voor het werkveld van schoolverlaters met een bepaalde opleidingsachtergrond (Wieling, De Grip en Van der Velden, 1992). Mogelijk komen schoolverlaters met een bepaalde opleidingsachtergrond in andere bedrijfssectoren of beroepen (met name 'groeisectoren') terecht dan waar de werkzame personen met de desbetreffende opleidingsachtergrond momenteel werkzaam zijn. Dit kan een indicatie vormen van toekomstige verschuivingen in het beroepsdomein van een bepaalde opleiding. Ook kunnen de verschillen in de arbeidsmarktbestemming van werkzame personen en schoolverlaters wijzen op toekomstige carrièremogelijkheden voor de schoolverlaters.

Bovendien zijn de schoolverlatersdata op een relatief laag aggregatieniveau beschikbaar, waardoor het in principe mogelijk is gedetailleerde informatie te verstrekken over de situatie op de arbeidsmarkt van schoolverlaters uit bepaalde opleidingsrichtingen. Bovendien gelden voor de schoolverlatersdata minder stringente publikatierestricties dan de door het CBS opgelegde bepalingen ten aanzien van de EBB, waardoor meer gedetailleerde gegevens over bijvoorbeeld de beroepen van schoolverlaters kunnen worden verstrekt. In bijlage $I$ is aangegeven in welke mate de bestaande ROA-opleidingstypen uit het Informatiesysteem verder kunnen worden gedifferentieerd. In plaats van 35 opleidingstypen (in AVO, LBO, MBO en $\mathrm{HBO}$ ) ${ }^{10}$ kunnen met

9. Daarbij moet wel worden gelet op de uniformiteit en koppelbaarheid van de indelingen in bedrijfs-, beroeps- en opleidingscategorieën.

10. Waaronder de niet reguliere opleidingstypen LBO Beveiliging en Bewaking, MBO Horeca en Kappers, MBO Politie en Defensie en HBO Politie en Defensie. 
behulp van de schoolverlatersenquêtes circa 100 opleidingsrichtingen onderscheiden worden.

Een belangrijke verbetering ten opzichte van de huidige situatie is ook dat in beide schoolverlatersbestanden een veel grotere verscheidenheid aan gegevens over de aansluiting tussen onderwijs en arbeidsmarkt beschikbaar is dan in de EBB. Op basis hiervan kunnen ook nieuwe arbeidsmarktindicatoren worden berekend. In hoofdstuk 3 wordt hiervan een aantal voorbeelden gepresenteerd. Deze betreffen met name de voor de functie die men uitoefent vereiste vakrichting, de aard van het dienstverband, het inkomen en de deelname aan aanvullende scholing.

Bovendien kunnen enkele conceptuele problemen van het huidige informatiesysteem onderwijsarbeidsmarkt waarschijnlijk voor een belangrijk deel worden opgelost met behulp van de schoolverlatersdata. Het beschikbaar zijn van gedetailleerde informatie over beroepen en branches levert een meer valide en betrouwbare indicatie op ten aanzien van spreidingsindicatoren c.q. uitwijkmogelijkheden naar beroepen en bedrijfssectoren.

Ook kan een meer valide en betrouwbare indicatie worden verkregen van het voor de uitgeoefende functies vereiste opleidingsniveau en daarmee van de mate van over- of onderbenutting. In het huidige informatiesysteem moet - noodgedwongen - worden gewerkt met een enigszins achterhaalde vaste functieniveau-indeling van op dit punt vaak onvoldoende homogene beroepsgroepen, zoals deze ook is gebruikt in de verschillende onderzoeken van Huijgen (zie bijvoorbeeld Huijgen, 1989). In de beide schoolverlatersonderzoeken is echter informatie beschikbaar over zowel het vereiste opleidingsniveau als de vereiste opleidingsrichting voor de functie die men uitoefent. Hierdoor kan op het niveau van afzonderlijke functies de aansluiting tussen onderwijs en arbeidsmarkt naar niveau en richting worden vastgelegd.

Ten slotte kunnen meer betrouwbare gegevens worden verstrekt over de werkloosheid onder schoolverlaters. Tot en met 1991 is in het informatiesysteem op basis van het bemiddelingsbestand zonder baan (BZB) specifieke informatie over de werkloosheid van schoolverlaters verstrekt (zie Beekman en De Grip, 1991 en Wieling, Dekker en De Grip, 1991). Dit bestand wordt, zoals algemeen bekend is, gekenmerkt door een vrij hoge mate van vervuiling. Bovendien kunnen deze gegevens niet zonder meer worden gerelateerd aan de populatie van schoolverlaters, zodat in feite een schatting moet worden gemaakt van het werkloosheidspercentage. Voorts is deze informatie de eerstkomende tijd niet beschikbaar doordat als gevolg van de decentralisatie van de Arbeidsvoorzieningsorganisatie de regionaal geregistreerde werkloosheidsdata niet eenduidig koppelbaar zijn. Op basis van de schoolverlatersgegevens kunnen meer betrouwbare werkloosheidsindicatoren worden opgesteld. Daarbij kan worden gedacht aan het werkloosheidspercentage onder schoolverlaters. In het verlengde hiervan kan worden nagegaan hoe groot de kans op werk is (zie Lodder, Ramaekers en Van der Velden, 1991). Naast het werkloosheidspercentage en de kans op werk geeft ook de werkloosheidsduur een belangrijke indicatie van de arbeidsmarktpositie van schoolverlaters. 
Door bovenstaande aspecten van de aansluitingsproblematiek tussen onderwijs en arbeidsmarkt voor de verschillende opleidingen in beeld te brengen, wordt een indicatie verkregen van de eventuele verschillen in de arbeidsmarktpositie van de (gediplomeerde) schoolverlaters van de onderscheiden opleidingen. Voor de aansluiting tussen onderwijs en arbeidsmarkt is het echter ook van belang om arbeidsmarktinformatie te genereren met betrekking tot de schoolverlaters die zonder diploma de laatstgevolgde opleiding hebben verlaten. Daarbij kan een onderscheid worden gemaakt tussen schoolverlaters die voortijdig hun opleiding in het $\mathrm{HBO}$ of MBO hebben verlaten en degenen die hun AVO of LBO studie hebben afgebroken. De zogenaamde drop-outs worden gevormd door deze laatste groep schoolverlaters, die geen enkele vorm van dagonderwijs heeft afgerond (zie Ministerie van Sociale Zaken en Werkgelegenheid, 1988 en Centraal Bestuur voor de Arbeidsvoorziening, 1991).

Naast de hierboven genoemde indicatoren kan meer inzicht worden verkregen in de arbeidsmarktpositie van schoolverlaters door het opstellen van (samengestelde) indicatoren die min of meer een totaalbeeld van de verschillende aspecten van de aansluiting tussen onderwijs en arbeidsmarkt geven. Daarbij wordt gedacht aan het opstellen van nieuwe indicatoren door het combineren van meerdere (reeds bestaande) indicatoren. In eerdere rapporten zijn reeds de werkloosheidscijfers met de mate van onderbenutting gecombineerd en de conjunctuurgevoeligheid met de uitwijkmogelijkheden, om op deze wijze te komen tot een meer algemene typering van actuele indicatoren en risico-indicatoren van de arbeidsmarktpositie van schoolverlaters (zie De Grip, Van der Velden en Wieling, 1993). Er kunnen echter ook andere en/of meer gegevens met elkaar worden gecombineerd op basis waarvan de arbeidsmarktsituatie van schoolverlaters kan worden getypeerd. Hierbij kan bijvoorbeeld worden gedacht aan de combinatie van het aantal opleidingsjaren en het arbeidsinkomen, waardoor een indicatie van het financiële rendement van de gevolgde leerroute kan worden verkregen. Aangezien de leerroutes van de schoolverlaters in dit rapport niet expliciet aan de orde komen, vormt deze combinatie van gegevens wellicht een aandachtspunt voor verdere ontwikkeling in de toekomst. Ook kan een combinatie worden gelegd tussen het functieniveau waarop de schoolverlaters werkzaam zijn en het inkomen dat zij daarbij verdienen (zie Wieling, 1991). In hoofdstuk 4 wordt een aantal voorbeelden gepresenteerd van samengestelde indicatoren. 
$-11-$

\section{ARBEIDSMARKTINDICATOREN VOOR SCHOOLVERLATERS}

\subsection{Inleiding}

Dit hoofdstuk zal door middel van de invulling van enkele indicatoren laten zien hoe schoolverlatersinformatie in het informatiesysteem onderwijs-arbeidsmarkt kan worden ingepast. Bij de presentatie van de indicatoren wordt, zoals in het vorige hoofdstuk reeds werd aangegeven, enerzijds ingegaan op de arbeidsmarktinformatie die tot op heden ook reeds in het informatiesysteem (actuele data en indicatoren) wordt verstrekt. Deze indicatoren dragen bij aan de verbetering van de arbeidsmarktinformatie doordat zij specifiek betrekking hebben op de eerste bestemmingen van schoolverlaters op de arbeidsmarkt. Bovendien kan de schoolverlatersinformatie op een gedetailleerder niveau worden gepresenteerd. Anderzijds zullen enkele indicatoren worden weergegeven die een belangrijke aanvulling op de huidige inhoud van het informatiesysteem geven. Bij de bespreking van de indicatoren zal het niet zozeer gaan om de uitkomsten als wel om de relevantie van de gepresenteerde informatie voor de verschillende gebruiksdoelen en om de vraag of de indicator bestaande arbeidsmarktinformatie kan vervangen of als een aanvulling kan fungeren.

Als gevolg van het feit dat de momenteel beschikbare schoolverlatersgegevens, door het ontbreken van vergelijkbare arbeidsmarktinformatie voor afgestudeerden in het WO, (nog) geen totaalbeeld opleveren voor de diverse bedrijfs- en beroepscategorieën, is er, zoals gezegd, in dit rapport voor gekozen de gevolgde opleiding als uitgangspunt te nemen voor de te genereren schoolverlatersinformatie. Voordat de verschillende indicatoren zullen worden besproken, zal allereerst in het kort worden ingegaan op de opleidingenindeling die is gehanteerd bij het opstellen van de indicatoren.

In navolging op de door het ROA gebruikte opleidingstypen in het informatiesysteem onderwijsarbeidsmarkt, zijn de in beide schoolverlatersbestanden onderscheiden opleidingen op basis van de Standaard Onderwijs Indeling (SOI) naar opleidingstype ingedeeld. Vervolgens is een onderverdeling gemaakt naar opleidingsrichting op basis van de indeling die in het RUBSonderzoek van 1992 (zie ook Wieling, Van de Loo en Van der Velden, 1993a en 1993b) en in de HBO-Monitor van 1991 (zie ook Van de Loo, Ramaekers en Van der Velden, 1992a tot en met $1992 \mathrm{f}$ ) is gehanteerd, waarbij in verband met de 'celvulling' rekening is gehouden met het aantal schoolverlaters dat in de desbetreffende opleidingsrichtingen voorkomt ${ }^{11}$.

Daarbij moet worden opgemerkt dat in de analyses de schoolverlaters van het Individueel Beroepsonderwijs (IBO) vooralsnog, buiten beschouwing zijn gelaten (zie ook Wieling, Van de Loo en Van der Velden, 1993a). In de HBO-Monitor worden ook schoolverlaters geënquêteerd die een deeltijd opleiding hebben gevolgd (zie Van de Loo, Ramaekers en Van der Velden, 1992a tot en met 1992f). Dit zijn vaak mensen die reeds op de arbeidsmarkt actief zijn of zijn

11. Doordat de 3-digit SOI-codes als uitgangspunt worden genomen, treden er enkele afwijkingen op ten opzichte van de indelingen die in de rapportages over het RUBS-project en de HBO-Monitor zijn gebruikt. 
geweest, zodat het hier doorgaans niet gaat om informatie met betrekking tot de eerste bestemming van schoolverlaters op de arbeidsmarkt. Derhalve zijn deze afgestudeerden hier buiten beschouwing gelaten.

Bij het trekken van de steekproef voor het RUBS-project van 1992 is getracht te komen tot een redelijke spreiding naar opleiding en regio, hetgeen het mogelijk maakt om voor alle in het onderzoek onderscheiden opleidingen betrouwbare informatie te geven. Door deze manier van steekproeftrekken kunnen echter kleinere regio's en kleinere opleidingsclusters oververtegenwoordigd zijn. Daarnaast kan als gevolg van de additionele metingen een ongelijke spreiding naar opleiding en regio optreden. Derhalve moet de gehele steekproef naderhand worden teruggewogen naar de landelijke verdeling (zie Wieling, Van de Loo en Van der Velden, 1993a en 1993b). Met uitzondering van de multivariate analyses is daar waar het gaat om gegevens van het RUBS-onderzoek gebruik gemaakt van de naar regio en opleiding herwogen data. Voor de HBO-Monitor heeft geen herweging plaatsgevonden, vanwege het ontbreken van afdoende populatiegegevens. Overigens participeren er zoveel HBO-afgestudeerden in het onderzoek dat er eigenlijk eerder sprake is van een populatie-onderzoek dan van een steekproefonderzoek (zie Van de Loo, Ramaekers en Van der Velden, 1992a tot en met 1992f).

Tabel 3.1. Aantallen werkende schoolverlaters per opleidingsrichting (gediplomeerde schoolverlaters)

LBO technisch: bouwtechniek $\quad 407$

LBO technisch: mechanische techniek 298

LBO technisch: elektrotechniek 229

LBO technisch: motorvoertuigentechniek 307

LBO technisch: consumptieve techniek 321

LBO technisch: installatietechniek 93

LBO technisch: grafische techniek 70

$\begin{array}{ll}\text { LBO technisch: overig } & 174\end{array}$

KMBO technisch: elektrotechniek $\quad 64$

KMBO technisch: metaalbewerking $\quad 60$

$\begin{array}{ll}\text { KMBO technisch: overig } & 168\end{array}$

MBO technisch laboratorium 90

MBO technisch: bouwkunde $\quad 79$

MBO technisch: elektrotechniek 207

MBO technisch: werktuigbouwkunde 163

MBO technisch: motorvoertuigentechniek $\quad 52$

MBO technisch: mode en kleding 223

$\begin{array}{ll}\text { MBO technisch: overig } & 248\end{array}$

$\begin{array}{ll}\text { HBO technisch laboratorium } & 157\end{array}$

HBO technisch: elektrotechniek $\quad 272$

HBO technisch: werktuigbouwkunde 258

HBO technisch: weg- en waterbouwkunde 93

HBO technisch: bouwkunde, bouwtechnische bedrijfskunde 96

HBO technisch: computertechniek, informatica $\quad 62$

HBO technisch: overig 162

$\begin{array}{ll}\text { HBO technische bedrijfskunde } & 155\end{array}$ 
Zoals in hoofdstuk 1 reeds is aangegeven zullen de verschillende indicatoren ter illustratie worden gepresenteerd voor de technische opleidingsrichtingen binnen het LBO, KMBO, MBO en HBO. Daarbij hebben de indicatoren die in dit hoofdstuk worden gepresenteerd betrekking op de schoolverlaters die hun opleiding met een diploma hebben afgesloten. Er zullen voor de verschillende indicatoren slechts resultaten worden gepresenteerd indien het aantal (werkende) schoolverlaters voor de onderscheiden opleidingsrichtingen 50 of meer bedraagt. In tabel 3.1 wordt een algemeen overzicht gegeven van het aantal schoolverlaters dat in de hier gepresenteerde opleidingsrichtingen voorkomt. Deze aantallen hebben betrekking op de werkzame schoolverlaters ${ }^{12}$ per opleidingsrichting, hetgeen voor vrijwel alle indicatoren het uitgangspunt vormt, met uitzondering van het werkloosheidspercentage en de duur van de intredewerkloosheid.

Aangezien de hier weergegeven resultaten slechts betrekking hebben op een beperkt aantal opleidingsrichtingen zal er geen kwalitatieve relatieve typering aan de uitkomsten worden gegeven. Indien over alle onderscheiden opleidingsrichtingen informatie wordt verschaft is het wel mogelijk de indicatoren te typeren (zie ook Wieling, De Grip en Willems, 1990). Deze typering maakt het mogelijk de verschillende opleidingsrichtingen op inzichtelijke wijze ten opzichte van elkaar te positioneren. Een punt van discussie is dan overigens nog of deze kwalitatieve typering over alle opleidingen moet worden vastgesteld of per opleidingsniveau. Hoewel voor de meeste indicatoren een typering over alle opleidingen de voorkeur verdient, is er een aantal indicatoren (bijvoorbeeld inkomen) waarbij een typering per niveau waarschijnlijk de voorkeur verdient.

\subsection{Actuele indicatoren}

In deze paragraaf komt een aantal actuele indicatoren aan de orde. Het gaat hier om indicatoren die doorgaans van jaar op jaar (sterk) kunnen variëren (zie ook De Grip, Van der Velden en Wieling, 1993). Daarbij wordt een onderscheid gemaakt tussen indicatoren die enerzijds betrekking hebben op de kans op werk en anderzijds indicatoren die inzicht geven in, wat men zou kunnen aanduiden als de kwaliteit van het werk. De kans op werk wordt geïndiceerd door het werkloosheidspercentage en de intredewerkloosheid, de kwaliteit van het werk door de benutting van de opleidingskwalificaties qua niveau en richting, het beroep en de branche waarin men werkzaam is, en het verdiende inkomen. In aanvulling daarop wordt ook ingegaan op de mate waarin schoolverlaters aanvullende cursussen en deeltijd opleidingen volgen, de aard van de aanstelling, de wekelijkse arbeidsduur, de grootte van de organisatie waarin men werkzaam is en de mate waarin er leidinggevend werk wordt verricht.

Het werkloosheidspercentage geeft een indicatie van de kans op werk op dit moment van degenen die een bepaalde opleiding hebben gevolgd. Tot en met 1991 is in het informatiesysteem op basis van het BZB informatie over de werkloosheid van schoolverlaters

12. Hieronder wordt verstaan het aantal schoolverlaters met een betaalde baan voor 12 uur of meer per week. 
verstrekt (zie ook Beekman en De Grip, 1991 en Wieling, Dekker en De Grip, 1991). Dit bestand wordt echter gekenmerkt door een vrij hoge mate van vervuiling en kan niet zonder meer worden gerelateerd aan populatiegegevens. Bovendien zijn de betreffende gegevens voor de laatste jaren niet meer beschikbaar. De werkloosheidsindicatoren die op basis van de schoolverlatersgegevens worden opgesteld, geven derhalve een meer betrouwbaar beeld van de kans op werk voor schoolverlaters. In tabel 3.2 worden de werkloosheidspercentages voor de gediplomeerden van de onderscheiden opleidingsrichtingen binnen het technisch onderwijs weergegeven op het moment van de enquête. Daarbij is de bepaling van de werkloosheid afgestemd op de wijze zoals het CBS de geregistreerde werkloosheid berekend ${ }^{13}$.

Tabel 3.2. Werkloosheidspercentage per opleidingsrichting (gediplomeerde schoolverlaters)

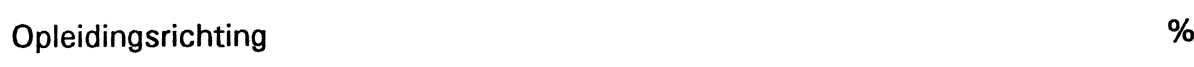

LBO technisch: bouwtechniek 2

LBO technisch: mechanische techniek 1

LBO technisch: elektrotechniek

LBO technisch: motorvoertuigentechniek 1

LBO technisch: consumptieve techniek 2

LBO technisch: installatietechniek 0

LBO technisch: grafische techniek $\quad 7$

LBO technisch: overig $\quad 7$

KMBO technisch: elektrotechniek 1

KMBO technisch: metaalbewerking $\quad 1$

KMBO technisch: overig $\quad 4$

MBO technisch laboratorium $\quad 6$

MBO technisch: bouwkunde 1

MBO technisch: elektrotechniek 5

MBO technisch: werktuigbouwkunde 3

MBO technisch: motorvoertuigentechniek 1

$\begin{array}{lll}\text { MBO } & \text { technisch: mode en kleding } & 6 \\ \text { MBO } & \text { technisch: overig } & 5\end{array}$

HBO technisch laboratorium

HBO technisch: elektrotechniek 11

HBO technisch: werktuigbouwkunde 9

HBO technisch: weg-en waterbouwkunde 0

HBO technisch: bouwkunde, bouwtechnische bedrijfskunde 3

HBO technisch: computertechniek, informatica

HBO technisch: overig 10

HBO technische bedrijfskunde $\quad 5$

Bron: RUBS 1992/HBO-Monitor 1991/ROA

Daarbij moet worden opgemerkt dat het peilmoment van beide schoolverlatersenquêtes niet gelijk heeft plaatsgevonden. Zoals in hoofdstuk 2 reeds is opgemerkt, zijn de schoolverlaters van het voortgezet onderwijs in het voorjaar van 1992 benaderd, terwijl de afgestudeerden van het HBO hun vragenlijst eind 1991 en begin 1992 hebben ingevuld. Een eventuele verslechte-

13. Zie hiervoor de definitie geregistreerde werkloosheid van 1991 (CBS, 1993a). 
ring of verbetering van de economische situatie kan derhalve een vertekend beeld te zien geven. Een wellicht nog belangrijker probleem hangt samen met de lengte van de periode dat de schoolverlaters op de arbeidsmarkt actief (kunnen) zijn. De schoolverlaters van het voortgezet onderwijs worden namelijk driekwart jaar na het verlaten van de opleiding geënquêteerd, terwijl de HBO-schoolverlaters ongeveer anderhalf jaar na afstuderen worden benaderd. Naarmate de periode, waarin men op de arbeidsmarkt actief is langer is, neemt de kans dat men een baan heeft gevonden toe. In beginsel kunnen beide problemen in belangrijke mate ondervangen worden. In de vragenlijst van de HBO-Monitor is namelijk gebruik gemaakt van een zogenaamde maandkalender waarin de schoolverlaters de voornaamste activiteit kunnen aangeven. Op basis van deze maandkalender kan voor de HBO-schoolverlaters evenals voor de schoolverlaters van het voortgezet onderwijs de werkloosheid driekwart jaar na het verlaten van de opleiding worden bepaald. Daarbij kan echter niet het werkloosheidscijfer volgens de officiële definitie van de geregistreerde werkloosheid worden bepaald, vanwege het feit dat een aantal gegevens ontbreken (zoals bijvoorbeeld het ingeschreven staan bij het Arbeidsbureau en het aantal uren dat men wil werken). Ook in de nieuwe vragenlijsten is dit probleem nog niet opgelost. In de toekomst zal echter worden gewerkt aan een betere afstemming tussen beide databestanden op dit punt.

In de schoolverlatersbestanden die in deze rapportage worden gebruikt, treedt bovendien een verschil op ten aanzien van de als werkloos getypeerde schoolverlaters. In de RUBS-enquête is rekening gehouden met het aantal uren dat een schoolverlater wil werken (dit moet 12 uur of meer per week zijn), terwijl in de HBO-Monitor van 1991 hiermee nog geen rekening is gehouden. Dit laatste komt doordat in de HBO-Monitor 1991, conform de toenmalige definitie van het CBS, iedereen die betaald werk had als werkend wordt getypeerd ongeacht het aantal uur dat men per week werkte. Vanwege de doorgevoerde verandering in de definitie van de werkzame personen in de EBB is, in de RUBS-enquête van 1992 het aantal uren dat men per week wil werken in de vragenlijst opgenomen. In de vragenlijst van de HBO-Monitor van 1992 is deze wijziging ook doorgevoerd, hetgeen impliceert dat de werkloosheidspercentages in beide schoolverlatersbestanden beter op elkaar aansluiten en op de vanaf 1994 geldende officiële definitie van werkloosheid.

In het verlengde van de werkloosheidspercentages kan ook de duur van de intredewerkloosheid een belangrijke indicatie geven van de kans op werk voor schoolverlaters. De duur van de intredewerkloosheid, dit wil zeggen de tijd dat de schoolverlaters werkloos zijn bij de intrede op de arbeidsmarkt, geeft een indicatie voor de mate waarin de intrede op de arbeidsmarkt succesvol verloopt. Daarbij wordt uitgegaan van het totaal aantal maanden dat de schoolverlaters werkloos zijn geweest na het verlaten van de opleiding. Met opzet is deze indicator niet beperkt tot de zoekduur tot de eerste baan. Immers, juist in het segment waar schoolverlaters vaak terechtkomen, is vaak sprake van tijdelijk werk. Het eerste jaar van de loopbaan van schoolverlaters kan daarom een instabiel karakter hebben, waarbij perioden van werk worden afgewisseld met perioden van werkloosheid. Er is daarom voor gekozen om het totaal aantal maanden dat iemand werkloos is geweest in het eerste jaar na het verlaten van de school, te gebruiken als indicator voor de intredewerkloosheid. In tabel 3.3 wordt voor de 
schoolverlaters het totaal aantal maanden weergegeven dat de schoolverlaters na het verlaten van de opleiding werkloos zijn geweest.

Tabel 3.3. Duur van de intredewerkloosheid per opleidingsrichting (gediplomeerde schoolverlaters)

\begin{tabular}{|c|c|c|c|c|c|}
\hline \multicolumn{2}{|c|}{ Opleidingsrichting } & $\begin{array}{c}\text { niet werkloos } \\
\text { geweest } \\
\%\end{array}$ & $\begin{array}{c}1-3 \\
\text { maanden } \\
\%\end{array}$ & $\begin{array}{c}4-6 \\
\text { maanden } \\
\%\end{array}$ & $\begin{array}{c}>6 \\
\text { maanden } \\
\%\end{array}$ \\
\hline $\begin{array}{l}\text { LBO } \\
\text { LBO } \\
\text { LBO } \\
\text { LBO } \\
\text { LBO } \\
\text { LBO } \\
\text { LBO } \\
\text { LBO }\end{array}$ & $\begin{array}{l}\text { techn.: bouwtechniek } \\
\text { techn.: mechanische techniek } \\
\text { techn.: elektrotechniek } \\
\text { techn.: motorvoertuigentechniek } \\
\text { techn.: consumptieve techniek } \\
\text { techn.: installatietechniek } \\
\text { techn.: grafische techniek } \\
\text { techn.: overig }\end{array}$ & $\begin{array}{l}91 \\
90 \\
85 \\
86 \\
83 \\
87 \\
67 \\
80\end{array}$ & $\begin{array}{r}7 \\
9 \\
11 \\
10 \\
12 \\
13 \\
18 \\
10\end{array}$ & $\begin{array}{l}1 \\
1 \\
1 \\
1 \\
3 \\
0 \\
5 \\
8\end{array}$ & $\begin{array}{r}1 \\
0 \\
2 \\
2 \\
1 \\
0 \\
10 \\
2\end{array}$ \\
\hline $\begin{array}{l}\text { KMBO } \\
\text { KMBO } \\
\text { KMBO }\end{array}$ & $\begin{array}{l}\text { techn.: elektrotechniek } \\
\text { techn.: metaalbewerking } \\
\text { techn.: overig }\end{array}$ & $\begin{array}{l}71 \\
74 \\
78\end{array}$ & $\begin{array}{l}22 \\
18 \\
15\end{array}$ & $\begin{array}{l}3 \\
8 \\
5\end{array}$ & $\begin{array}{l}4 \\
0 \\
2\end{array}$ \\
\hline MBO & technisch laboratorium & 65 & 26 & 7 & 1 \\
\hline $\begin{array}{l}\text { MBO } \\
\text { MBO } \\
\text { MBO } \\
\text { MBO } \\
\text { MBO } \\
\text { MBO }\end{array}$ & $\begin{array}{l}\text { techn.: bouwkunde } \\
\text { techn.: elektrotechniek } \\
\text { techn.: werktuigbouwkunde } \\
\text { techn.: motorvoertuigentechniek } \\
\text { techn.: mode en kleding } \\
\text { techn.: overig }\end{array}$ & $\begin{array}{l}82 \\
74 \\
80 \\
91 \\
70 \\
71\end{array}$ & $\begin{array}{r}14 \\
19 \\
14 \\
4 \\
20 \\
18\end{array}$ & $\begin{array}{l}2 \\
6 \\
4 \\
2 \\
7 \\
7\end{array}$ & $\begin{array}{l}1 \\
1 \\
2 \\
4 \\
4 \\
4\end{array}$ \\
\hline HBO & technisch laboratorium & 77 & 19 & 3 & 1 \\
\hline $\begin{array}{l}\text { HBO } \\
\text { HBO } \\
\text { HBO } \\
\text { HBO } \\
\text { HBO } \\
\text { HBO }\end{array}$ & $\begin{array}{l}\text { techn.: elektrotechniek } \\
\text { techn.: werktuigbouwkunde } \\
\text { techn.: weg- en waterbouwkunde } \\
\text { techn.: bouwkunde, bouwtechn. bedrijfskunde } \\
\text { techn.: computertechniek, informatica } \\
\text { techn.: overig }\end{array}$ & $\begin{array}{l}66 \\
73 \\
83 \\
76 \\
58 \\
69\end{array}$ & $\begin{array}{l}26 \\
23 \\
16 \\
19 \\
32 \\
24\end{array}$ & $\begin{array}{l}5 \\
4 \\
1 \\
3 \\
9 \\
4\end{array}$ & $\begin{array}{l}3 \\
1 \\
0 \\
2 \\
2 \\
3\end{array}$ \\
\hline HBO & technische bedrijfskunde & 63 & 29 & 5 & 2 \\
\hline
\end{tabular}

Bron: RUBS 1992/HBO-Monitor 1991/ROA

In de RUBS-enquête is aan de schoolverlaters gevraagd naar het totaal aantal maanden dat men na het verlaten van opleiding werkloos is geweest. In de HBO-monitor kan op basis van de in de vragenlijst opgenomen maandkalender worden nagegaan hoeveel maanden men werkloos is geweest. Het is echter mogelijk dat door het niet volledig invullen van deze vraag de intredewerkloosheid van de afgestudeerden van het $\mathrm{HBO}$ wordt onderschat. Aan de andere kant is de periode tussen het verlaten van de opleiding en het invullen van de vragenlijst voor veel HBO-ers langer dan voor de schoolverlaters van het voortgezet onderwijs. Ook hier kan net zoals bij de werkloosheidspercentages op basis van de maandkalender-vraag in de HBO-Monitor een correctie worden doorgevoerd, zodat de periode waarover deze intredewerkloosheid wordt bepaald in beide enquêtes beter overeenkomt. In tabel 3.3 is het aantal maanden dat de afgestudeerden van het $\mathrm{HBO}$ werkloos zijn geweest bepaald op basis van de eerste 12 maanden na het verlaten van de opleiding. Daarbij moet worden opgemerkt dat het weinig zinvol is de 
duur van de intredewerkloosheid te bepalen voor degenen die niet aan het arbeidsproces (willen) deelnemen, derhalve is deze indicator slechts bepaald op basis van de gediplomeerden in het bezit van een betaalde baan van 12 uur of meer per week of de als werkloos getypeerde schoolverlaters.

Overigens hebben er in de vragenlijsten van RUBS en de HBO-Monitor van 1993 enkele aanpassingen plaatsgevonden, zodat er in de komende jaren ook inzicht kan worden verkregen in de zogenaamde 'baanzoekduren' (zie ook Berkhout en Mot, 1992 en Van der Valk en Berkhout, 1992). Met behulp van de baanzoekduren kan de volledige zoekperiode in beeld worden gebracht. Er kan bovendien worden nagegaan of de schoolverlaters een baan hebben gevonden die enigszins aansluit bij de gevolgde opleiding. Daarbij wordt in bovengenoemd onderzoek de werkkring als voldoende 'aansluitend' beoordeeld als het een werkkring van 12 uur of meer per week met een niet flexibel contract betreft. Het is echter ook mogelijk op basis van de beide schoolverlatersenquêtes andere criteria hiervoor te kiezen.

In aanvulling op de kans op werk voor de verschillende opleidingsrichtingen, kan een beeld worden geschetst van de kwaliteit van het door schoolverlaters uitgeoefend werk. Een cruciale maatstaf hiervoor is het percentage werkenden dat in hun kwalificaties wordt onder- of overbenut. $\mathrm{Er}$ is sprake van onderbenutting als het niveau van het beroep dat door de schoolverlaters wordt uitgeoefend lager is dan het niveau van de voltooide opleiding. Daarentegen wordt een schoolverlater overbenut als het niveau van de uitgeoefende functie hoger is dan het niveau van de gevolgde opleiding. Met betrekking tot het interpreteren van de resultaten moet echter worden opgemerkt, dat het hier gaat om startfuncties, waarbij mogelijk nog doorgroeimogelijkheden naar een niveau dat aansluit bij de gevolgde opleiding aanwezig zijn (zie De Grip, Heijke, Willems, 1992). Echter, een hoog onderbenuttingspercentage geeft terdege een indicatie van een slechte marktpositie voor de desbetreffende opleiding.

Schema 1. Onder- en overbenuttingsmodel

$\begin{array}{lll}\text { Opleidingsniveau onderbenutting } & \text { overbenutting }\end{array}$

\begin{tabular}{lll} 
Basisonderwijs & \multicolumn{1}{c}{$4,5,6,7$} \\
MAVO, LBO & 1,2 & $5,6,7$ \\
HAVO, VWO, MBO & $1,2,3$ & 6,7 \\
HBO & $1,2,3,4$ & 7 \\
WO & $1,2,3,4,5$ & -
\end{tabular}

Bron: Huijgen (1989)

In het informatiesysteem wordt tot op heden de mate van benutting gemeten aan de hand van een vaste indeling in functieniveaus die worden toegekend aan de beroepen volgens de CBSberoepenclassificatie op 4-digitniveau (zie Huijgen, 1989). Het functieniveau wordt toegekend op basis van een 7-punts functieniveau-indeling, waarbij niveau 1 betrekking heeft op erg eenvoudig werk en niveau 7 werk van wetenschappelijke aard vertegenwoordigt. In schema 1 wordt voor de verschillende opleidingsniveaus weergegeven welke functieniveaus volgens deze 
methode voor de schoolverlaters van de verschillende opleidingsniveaus respectievelijk een onder- of overbenutting van het kwalificatieniveau van de schoolverlaters impliceren ${ }^{14}$.

Bovenstaande methode om de onder- en overbenutting te bepalen heeft als nadeel dat gebruik moet worden gemaakt van een vaste functieniveau-indeling. In deze functieniveau-indeling wordt geen rekening gehouden met eventuele variatie in niveau die kan voorkomen in eenzelfde beroep. Een beroep krijgt steevast hetzelfde functieniveau toegekend, terwijl er in feite binnen hetzelfde beroep functies op verschillende niveaus kunnen voorkomen. Bovendien is de bovenstaande functieniveau-indeling enigszins verouderd. Recentelijk heeft het CBS de nieuwe Standaard Beroepenclassificatie 1992 (SBC'92) ontwikkeld (zie CBS, 1993b). In deze SBC'92 zijn de bekwaamheden die nodig om een bepaald takenpakket uit te voeren als uitgangspunt genomen, hetgeen mede wordt geïndiceerd door het niveau van de 'meest geëigende opleiding'. Enkele nadelen van bovenstaande functieniveau-indeling worden door deze nieuwe indeling opgelost. Het probleem van de vaste functieniveau-typering per beroep blijft echter bestaan.

De schoolverlatersenquêtes bieden de mogelijkheid om te komen tot een meer recente en waarschijnlijk ook meer betrouwbare beoordelingsmaatstaf voor de aansluiting tussen het niveau van het gevolgde onderwijs en het niveau van het door een schoolverlater uitgeoefende werk. In de enquête is namelijk gevraagd naar het minimaal vereiste opleidingsniveau voor de ten tijde van de enquête uitgeoefende functie. Indien dit onder het daadwerkelijk gevolgde niveau ligt, wijst dat op een onderbenutting van capaciteiten bij de uitoefening van de functie. Bij een hoger vereist opleidingsniveau dan het feitelijk door de schoolverlater voltooide niveau is er daarentegen sprake van overbenutting. Voor het vaststellen van de eventuele onder- en overbenutting zijn de gevolgde opleiding en de door de werkgever gevraagde opleiding ingedeeld in zes niveaus ${ }^{15}$.

In tabel 3.4 worden de percentages onder- en overbenutting per opleidingsrichting gepresenteerd volgens de beide hierboven beschreven methoden. Uit deze tabel blijkt dat de mate van onderbenutting bepaald op basis van de functieniveau-indeling van Huijgen bij de meeste onderscheiden opleidingsrichtingen beduidend hoger is dan wanneer gebruik wordt gemaakt van informatie over de volgens de schoolverlaters voor hun functie minimaal vereiste opleidingsniveau. Bij verschillende technische opleidingsrichtingen binnen het $\mathrm{HBO}$ doet zich het omgekeerde beeld voor. Daarentegen is bij de technische opleidingsrichtingen op LBO-niveau het op basis van de functieniveau-indeling van Huijgen bepaalde percentage overbenutting aanmerkelijk lager dan de op basis van de opgenomen vragen in de schoolverlatersenquêtes

14. In plaats van onderbenutting kan men hier ook spreken van overscholing en in plaats van overbenutting wordt ook wel gesproken van onderscholing.

15. De gevolgde en de vereiste opleidingen zijn als volgt naar niveau ingedeeld:

1 = geen opleiding of alleen lagere school

2 = LBO, MAVO

$3=\mathrm{KMBO}$, Leerlingwezen

$4=\mathrm{MBO}, \mathrm{HAVO}, \mathrm{VWO}$

$5=\mathrm{HBO}$

$6=\mathrm{WO}$ 
berekende overbenutting. Dit kan wellicht worden verklaard uit het grote aantal LBOschoolverlaters dat een opleiding in het leerlingwezen of het in-service onderwijs is gaan volgen. Het gaat daarbij om functies waarbij LBO-ers verder worden opgeleid. Mogelijk heeft een aantal van deze schoolverlaters in de vragenlijst aangegeven dat voor de uitgeoefende functie een opleiding op het niveau van de op het moment van de enquête gevolgde deeltijd opleiding werd vereist, waardoor er bij deze aanpak overbenutting wordt geconstateerd.

Tabel 3.4. Benutting per opleidingsrichting (gediplomeerde schoolverlaters)

\begin{tabular}{|c|c|c|c|c|c|}
\hline \multirow{2}{*}{\multicolumn{2}{|c|}{ Opleidingsrichting }} & \multicolumn{2}{|c|}{ Huijgen } & \multicolumn{2}{|c|}{ vereist niveau } \\
\hline & & $\begin{array}{l}\text { onder- } \\
\text { benutting } \\
\%\end{array}$ & $\begin{array}{l}\text { over- } \\
\text { benutting } \\
\%\end{array}$ & $\begin{array}{c}\text { onder- } \\
\text { benutting } \\
\%\end{array}$ & $\begin{array}{c}\text { over- } \\
\text { benutting } \\
\%\end{array}$ \\
\hline $\begin{array}{l}\text { LBO } \\
\text { LBO } \\
\text { LBO } \\
\text { LBO } \\
\text { LBO } \\
\text { LBO } \\
\text { LBO } \\
\text { LBO }\end{array}$ & $\begin{array}{l}\text { techn.: bouwtechniek } \\
\text { techn.: mechanische techniek } \\
\text { techn.: elektrotechniek } \\
\text { techn.: motorvoertuigentechniek } \\
\text { techn.: consumptieve techniek } \\
\text { techn.: installatietechniek } \\
\text { techn.: grafische techniek } \\
\text { techn.: overig }\end{array}$ & $\begin{array}{r}13 \\
35 \\
30 \\
25 \\
31 \\
6 \\
25 \\
66\end{array}$ & $\begin{array}{l}0 \\
2 \\
0 \\
0 \\
1 \\
2 \\
3 \\
1\end{array}$ & $\begin{array}{r}13 \\
14 \\
19 \\
10 \\
17 \\
7 \\
22 \\
34\end{array}$ & $\begin{array}{r}12 \\
17 \\
11 \\
16 \\
22 \\
7 \\
18 \\
17\end{array}$ \\
\hline $\begin{array}{l}\text { KMBO } \\
\text { KMBO } \\
\text { KMBO }\end{array}$ & $\begin{array}{l}\text { techn.: elektrotechniek } \\
\text { techn.: metaalbewerking } \\
\text { techn.: overig }\end{array}$ & $\begin{array}{l}32 \\
67 \\
52\end{array}$ & $\begin{array}{l}0 \\
0 \\
1\end{array}$ & $\begin{array}{l}48 \\
53 \\
30\end{array}$ & $\begin{array}{r}8 \\
10 \\
9\end{array}$ \\
\hline MBO & technisch laboratorium & 39 & 0 & 21 & 3 \\
\hline $\begin{array}{l}\text { MBO } \\
\text { MBO } \\
\text { MBO } \\
\text { MBO } \\
\text { MBO } \\
\text { MBO }\end{array}$ & $\begin{array}{l}\text { techn.: bouwkunde } \\
\text { techn.: elektrotechniek } \\
\text { techn.: werktuigbouwkunde } \\
\text { techn.: motorvoertuigentechniek } \\
\text { techn.: mode en kleding } \\
\text { techn.: overig }\end{array}$ & $\begin{array}{l}13 \\
17 \\
28 \\
20 \\
79 \\
47\end{array}$ & $\begin{array}{l}0 \\
3 \\
4 \\
4 \\
3 \\
5\end{array}$ & $\begin{array}{l}12 \\
18 \\
18 \\
14 \\
44 \\
20\end{array}$ & $\begin{array}{l}3 \\
1 \\
1 \\
4 \\
1 \\
1\end{array}$ \\
\hline $\mathrm{HBO}$ & technisch laboratorium & 43 & 15 & 6 & 6 \\
\hline $\begin{array}{l}\text { HBO } \\
\text { HBO } \\
\text { HBO } \\
\text { HBO } \\
\text { HBO } \\
\text { HBO }\end{array}$ & $\begin{array}{l}\text { techn.: elektrotechniek } \\
\text { techn.: werktuigbouwkunde } \\
\text { techn.: weg- en waterbouwkunde } \\
\text { techn.: bouwkunde, bouwtechn. bedrijfskunde } \\
\text { techn.: computertechniek, informatica } \\
\text { techn.: overig }\end{array}$ & $\begin{array}{r}5 \\
11 \\
3 \\
0 \\
3 \\
16\end{array}$ & $\begin{array}{r}25 \\
5 \\
51 \\
36 \\
30 \\
27\end{array}$ & $\begin{array}{r}13 \\
10 \\
13 \\
20 \\
3 \\
14\end{array}$ & $\begin{array}{l}3 \\
5 \\
0 \\
1 \\
8 \\
6\end{array}$ \\
\hline HBO & technische bedrijfskunde & 24 & 14 & 12 & 9 \\
\hline
\end{tabular}

Bron: RUBS 1992/HBO-Monitor 1991/ROA

In aanvulling op de aansluiting naar kwalificatie- c.q. opleidingsniveau kan op basis van de schoolverlatersbestanden ook inzicht worden verkregen in de aansluiting van de functie waarin men terecht is gekomen en de gevolgde opleidingsrichting. In de vragenlijsten van zowel RUBS als de HBO-Monitor is gevraagd naar de vakrichting die werd vereist voor de functie die men op het moment van enquêteren uitoefent (zie tabel 3.5). Daarmee wordt informatie verkregen over de segmenten waarin de schoolverlaters terechtkomen. Indien een groot percentage schoolverlaters aangeeft dat geen specifieke vakrichting werd vereist, kan dit aangeven dat de 
schoolverlaters zich in een breed toegankelijk arbeidsmarktsegment bevinden waarin zij veel concurrentie ondervinden van schoolverlaters met een andere opleidingsachtergrond. Wordt daarentegen in de meeste banen waarin de schoolverlaters van een bepaalde opleidingsrichting terechtkomen, de gevolgde vakrichting of een nauw verwante richting vereist, dan geeft dit een indicatie van sterk afgebakende arbeidsmarktsegmenten, die doorgaans getypeerd worden als 'vakdeelmarkten'16.

Tabel 3.5. Vereiste vakrichting voor de functie die men uitoefent per opleidingsrichting (gediplomeerde schoolverlaters)

\begin{tabular}{|c|c|c|c|c|}
\hline \multicolumn{2}{|c|}{ Opleidingsrichting } & $\begin{array}{l}\text { eigen/verwante } \\
\text { richting } \\
\%\end{array}$ & $\begin{array}{c}\text { andere } \\
\text { richting } \\
\%\end{array}$ & $\begin{array}{c}\text { geen specifieke } \\
\text { richting } \\
\%\end{array}$ \\
\hline $\begin{array}{l}\text { LBO } \\
\text { LBO } \\
\text { LBO } \\
\text { LBO } \\
\text { LBO } \\
\text { LBO } \\
\text { LBO } \\
\text { LBO }\end{array}$ & $\begin{array}{l}\text { technisch: bouwtechniek } \\
\text { technisch: mechanische techniek } \\
\text { technisch: elektrotechniek } \\
\text { technisch: motorvoertuigentechniek } \\
\text { technisch: consumptieve techniek } \\
\text { technisch: installatietechniek } \\
\text { technisch: grafische techniek } \\
\text { technisch: overig }\end{array}$ & $\begin{array}{l}58 \\
38 \\
46 \\
56 \\
59 \\
63 \\
52 \\
20\end{array}$ & $\begin{array}{l}2 \\
7 \\
3 \\
3 \\
3 \\
5 \\
6 \\
2\end{array}$ & $\begin{array}{l}40 \\
55 \\
51 \\
41 \\
38 \\
32 \\
42 \\
77\end{array}$ \\
\hline $\begin{array}{l}\text { KMBO } \\
\text { KMBO } \\
\text { KMBO }\end{array}$ & $\begin{array}{l}\text { technisch: elektrotechniek } \\
\text { technisch: metaalbewerking } \\
\text { technisch: overig }\end{array}$ & $\begin{array}{l}57 \\
45 \\
51\end{array}$ & $\begin{array}{l}2 \\
5 \\
3\end{array}$ & $\begin{array}{l}41 \\
50 \\
46\end{array}$ \\
\hline MBO & technisch laboratorium & 68 & 6 & 26 \\
\hline $\begin{array}{l}\text { MBO } \\
\text { MBO } \\
\text { MBO } \\
\text { MBO } \\
\text { MBO } \\
\text { MBO }\end{array}$ & $\begin{array}{l}\text { technisch: bouwkunde } \\
\text { technisch: elektrotechniek } \\
\text { technisch: werktuigbouwkunde } \\
\text { technisch: motorvoertuigentechniek } \\
\text { technisch: mode en kleding } \\
\text { technisch: overig }\end{array}$ & $\begin{array}{l}79 \\
68 \\
63 \\
69 \\
24 \\
67\end{array}$ & $\begin{array}{l}1 \\
4 \\
5 \\
4 \\
5 \\
2\end{array}$ & $\begin{array}{l}20 \\
29 \\
32 \\
27 \\
71 \\
32\end{array}$ \\
\hline HBO & technisch laboratorium & 93 & 2 & 5 \\
\hline $\begin{array}{l}\text { HBO } \\
\text { HBO } \\
\text { HBO } \\
\text { HBO } \\
\text { HBO } \\
\text { HBO }\end{array}$ & $\begin{array}{l}\text { technisch: elektrotechniek } \\
\text { technisch: werktuigbouwkunde } \\
\text { technisch: weg- en waterbouwkunde } \\
\text { technisch: bouwkunde, bouwtechn. bedrijfskunde } \\
\text { technisch: computertechniek, informatica } \\
\text { technisch: overig }\end{array}$ & $\begin{array}{l}86 \\
90 \\
98 \\
94 \\
97 \\
83\end{array}$ & $\begin{array}{l}4 \\
2 \\
0 \\
3 \\
0 \\
4\end{array}$ & $\begin{array}{r}11 \\
8 \\
2 \\
3 \\
3 \\
13\end{array}$ \\
\hline HBO & technische bedrijfskunde & 79 & 6 & 15 \\
\hline
\end{tabular}

Bron: RUBS 1992/HBO-Monitor 1991/ROA

Een belangrijk aspect waarmee meer inzicht kan worden verkregen in de kwaliteit van het werk, is het beroep en de branche waarin de schoolverlaters terechtkomen. In tabel 1 en 2 van bijlage

16. Overigens moet worden opgemerkt dat bij onderbenutting van de aanwezige kwalificaties de vereiste vakrichting mogelijk van minder belang zal zijn. Dit pleit er voor om de vereiste opleidingsrichting in samenhang te bezien met het niveau waarop de gediplomeerden werkzaam zijn (zie ook ROA, 1993a). 
II wordt respectievelijk aangegeven in welke beroepsgroepen en bedrijfsklassen ${ }^{17}$ de schoolverlaters op het moment van enquêteren werkzaam zijn. Het voordeel van het gebruik maken van de schoolverlatersenquêtes is dat het mogelijk is per opleidingsrichting op een gedetailleerd niveau te bepalen in welke beroepen en branches de schoolverlaters terechtkomen. Hierdoor sluit de informatie voor schoolverlaters direct aan bij hun eigen specifieke achtergrond. De beroepen- en branche-informatie per opleidingstype die tot op heden wordt verstrekt in het informatiesysteem geeft in dit opzicht een te weinig gedetailleerd beeld, waardoor meer uniformiteit tussen opleidingen wordt gesuggereerd dan feitelijk aanwezig is.

Een uiterst interessant gegeven is het loon dat door de schoolverlaters kan worden verdiend na het voltooien van een opleiding. In tegenstelling tot de momenteel beschikbare gegevens kan op basis van de schoolverlatersenquêtes worden nagegaan wat de inkomenspositie van de schoolverlaters van de onderscheiden opleidingsrichtingen is. In de eerste plaats is dat, in aanvulling op de bovengenoemde indicatoren, waardevolle informatie voor de studie- en beroepskeuzevoorlichting. Bovendien kan deze indicator meer in het algemeen een beeld geven van de vraag-aanbod verhoudingen voor de verschillende opleidingsrichtingen op de arbeidsmarkt. Zoals er werkloosheid optreedt in geval van een ruime arbeidsmarkt, kan een relatief hoog inkomen duiden op een krappe arbeidsmarkt. Met betrekking tot de aansluiting tussen beide schoolverlatersbestanden moet worden opgemerkt dat in de RUBS-vragenlijst van 1992 nog wordt gevraagd naar het netto (maand)inkomen, terwijl in de HBO-vragenlijst het bruto (maand)inkomen moet worden opgegeven. Dit bemoeilijkt de vergelijkbaarheid van de beloning van de HBO-ers en de schoolverlaters van het voortgezet onderwijs. Vanaf 1993 wordt in de RUBS-vragenlijst echter in navolging van de HBO-Monitor eveneens gevraagd naar het bruto maandloon.

Om te voorkomen dat er een grote hoeveelheid informatie moet worden gepresenteerd, kan een indicatie van het te verdienen inkomen worden gegeven door het gemiddelde loon op te nemen (zie tabel 3.6). Het gemiddelde loon zegt echter niets over de verschillen die kunnen optreden met betrekking tot het verdiende inkomen van de werkende schoolverlaters (zie De Grip, Van der Velden en Wieling, 1991). Derhalve kan naast het gemiddelde ook de standaarddeviatie per opleidingsrichting worden opgenomen. Voor een makkelijke interpretatie van deze indicatoren zou een kwalitatieve typering aan de berekende waarden kunnen worden toegekend. Het is echter de vraag of deze informatie het meest geschikt is om op te nemen in het informatiesysteem onderwijs-arbeidsmarkt. Het is ook mogelijk om looninformatie op te nemen in de vorm van het modale inkomen van de schoolverlaters met een bepaalde opleidingsachtergrond of een percentage schoolverlaters per opleidingsrichting dat relatief weinig verdient. Een indicatie van dit laatste wordt gegeven in de laatste kolom van tabel 3.6.

17. Wat betreft de indeling van de beroepen en branches wordt gebruik gemaakt van respectievelijk de beroepenclassificatie van het CBS en de Standaard Bedrijfsindeling (SBI) op 4-digitniveau. Overigens zal in dit rapport vanwege de overzichtelijkheid de informatie op beroepsgroepenniveau (3-digit) en bedrijfsklassenniveau (2-digit) worden gepresenteerd. 
Tabel 3.6. Uurloon per opleidingsrichting (gediplomeerde schoolverlaters)

\begin{tabular}{|c|c|c|c|c|}
\hline \multicolumn{2}{|c|}{ Opleidingsrichting } & $\begin{array}{l}\text { gemiddelde } \\
\text { (in guldens) }\end{array}$ & $\begin{array}{l}\text { standaard- } \\
\text { deviatie }\end{array}$ & $\begin{array}{l}\text { laag inkomen } \\
\%\end{array}$ \\
\hline \multicolumn{5}{|c|}{ netto uurinkomen } \\
\hline $\begin{array}{l}\text { LBO } \\
\text { LBO } \\
\text { LBO } \\
\text { LBO } \\
\text { LBO } \\
\text { LBO } \\
\text { LBO }\end{array}$ & $\begin{array}{l}\text { technisch: bouwtechniek } \\
\text { technisch: mechanische techniek } \\
\text { technisch: elektrotechniek } \\
\text { technisch: motorvoertuigentechniek } \\
\text { technisch: consumptieve techniek } \\
\text { technisch: installatietechniek } \\
\text { technisch: grafische techniek } \\
\text { technisch: overig }\end{array}$ & $\begin{array}{l}6,26 \\
5,90 \\
5,66 \\
5,60 \\
6,47 \\
5,65 \\
7,35 \\
5,43\end{array}$ & $\begin{array}{l}1,57 \\
1,89 \\
1,81 \\
1,82 \\
1,90 \\
1,18 \\
2,08 \\
1,74\end{array}$ & $\begin{array}{r}11 \\
23 \\
34 \\
34 \\
14 \\
28 \\
9 \\
41\end{array}$ \\
\hline $\begin{array}{l}\text { KMBO } \\
\text { KMBO } \\
\text { KMBO }\end{array}$ & $\begin{array}{l}\text { technisch: elektrotechniek } \\
\text { technisch: metaalbewerking } \\
\text { technisch: overig }\end{array}$ & $\begin{array}{l}7,40 \\
8,37 \\
8,24\end{array}$ & $\begin{array}{l}2,18 \\
1,65 \\
2,27\end{array}$ & $\begin{array}{l}30 \\
13 \\
23\end{array}$ \\
\hline MBO & technisch laboratorium & 10,41 & 1,87 & 6 \\
\hline $\begin{array}{l}\text { MBO } \\
\text { MBO } \\
\text { MBO } \\
\text { MBO } \\
\text { MBO } \\
\text { MBO }\end{array}$ & $\begin{array}{l}\text { technisch: bouwkunde } \\
\text { technisch: elektrotechniek } \\
\text { technisch: werktuigbouwkunde } \\
\text { technisch: motorvoertuigentechniek } \\
\text { technisch: mode en kleding } \\
\text { technisch: overig }\end{array}$ & $\begin{array}{r}10,13 \\
10,13 \\
10,30 \\
10,64 \\
7,78 \\
10,21\end{array}$ & $\begin{array}{l}2,48 \\
2,68 \\
2,81 \\
3,11 \\
1,96 \\
2,32\end{array}$ & $\begin{array}{r}6 \\
9 \\
9 \\
7 \\
50 \\
8\end{array}$ \\
\hline \multicolumn{5}{|c|}{ bruto uurinkomen } \\
\hline HBO & technisch laboratorium & 18,94 & 4,07 & 15 \\
\hline $\begin{array}{l}\text { HBO } \\
\text { HBO } \\
\text { HBO } \\
\text { HBO } \\
\text { HBO } \\
\text { HBO }\end{array}$ & $\begin{array}{l}\text { technisch: elektrotechniek } \\
\text { technisch: werktuigbouwkunde } \\
\text { technisch: weg- en waterbouwkunde } \\
\text { technisch: bouwkunde, bouwtechn. bedrijfskunde } \\
\text { technisch: computertechniek, informatica } \\
\text { technisch: overig }\end{array}$ & $\begin{array}{l}19,57 \\
19,30 \\
19,17 \\
19,43 \\
19,81 \\
20,13\end{array}$ & $\begin{array}{l}3,23 \\
2,91 \\
2,27 \\
3,47 \\
2,63 \\
5,01\end{array}$ & $\begin{array}{r}8 \\
10 \\
9 \\
15 \\
8 \\
9\end{array}$ \\
\hline HBO & technische bedrijfskunde & 20,86 & 3,66 & 7 \\
\hline
\end{tabular}

Bron: RUBS 1992/HBO-Monitor 1991/ROA

Met betrekking tot het percentage schoolverlaters dat een relatief laag inkomen verdient, kan vanwege de sporadisch beschikbare loongegevens, helaas geen van de data onafhankelijke indeling worden gehanteerd. Derhalve is er in dit geval voor gekozen om op basis van het gemiddelde inkomen per opleidingsniveau en de bijbehorende standaarddeviatie een indeling te maken tussen schoolverlaters die een relatief laag inkomen verdienen en degenen die een gemiddeld of hoger inkomen verdienen (voor de wijze van indelen zie Wieling, De Grip en Willems, 1990$)^{18}$. Dit heeft echter wel tot gevolg dat per niveau de inkomenssituatie van ongeveer $30 \%$ van de schoolverlaters als relatief slecht wordt getypeerd. Hierbij zij nogmaals opgemerkt dat het bij de deelnemers aan de RUBS-enquête gaat om het netto uurloon, terwijl het bij de afgestudeerden van het HBO gaat om het bruto uurinkomen. Omdat de mate van

18. Degenen die volgens deze kwalitatieve typering een inkomen verdienen dat relatief laag of erg laag is, worden hier beide tot de groep met een relatief slechte inkomenspositie gerekend. 
onderbetaling echter per niveau is vastgesteld, zal dit verschil in meetmethode voor de uiteindelijke rangorde weinig consequenties hebben.

Er moet overigens worden opgemerkt dat in tabel 3.6 het uurloon wordt weergegeven om vertekening door het aantal uren dat de schoolverlaters per week werken te voorkomen. Wellicht is het echter voor de interpreteerbaarheid van de informatie, voor met name de studieen beroepskeuzevoorlichting, aan te raden dit uurloon om te rekenen naar het maandloon dat de schoolverlaters verdienen bij een volledige werkweek. Bij het uurloon kan bovendien een vertekening optreden ten aanzien van opleidingen waarin veel mensen slechts weinig uren kunnen werken en derhalve gedeeltelijk werkloos zijn. In die gevallen kan het meer informatief zijn om het feitelijke maandinkomen te presenteren.

Tabel 3.7. Deelname aan aanvullende cursussen en deeltijd opleidingen per opleidingsrichting (gediplomeerde schoolverlaters)

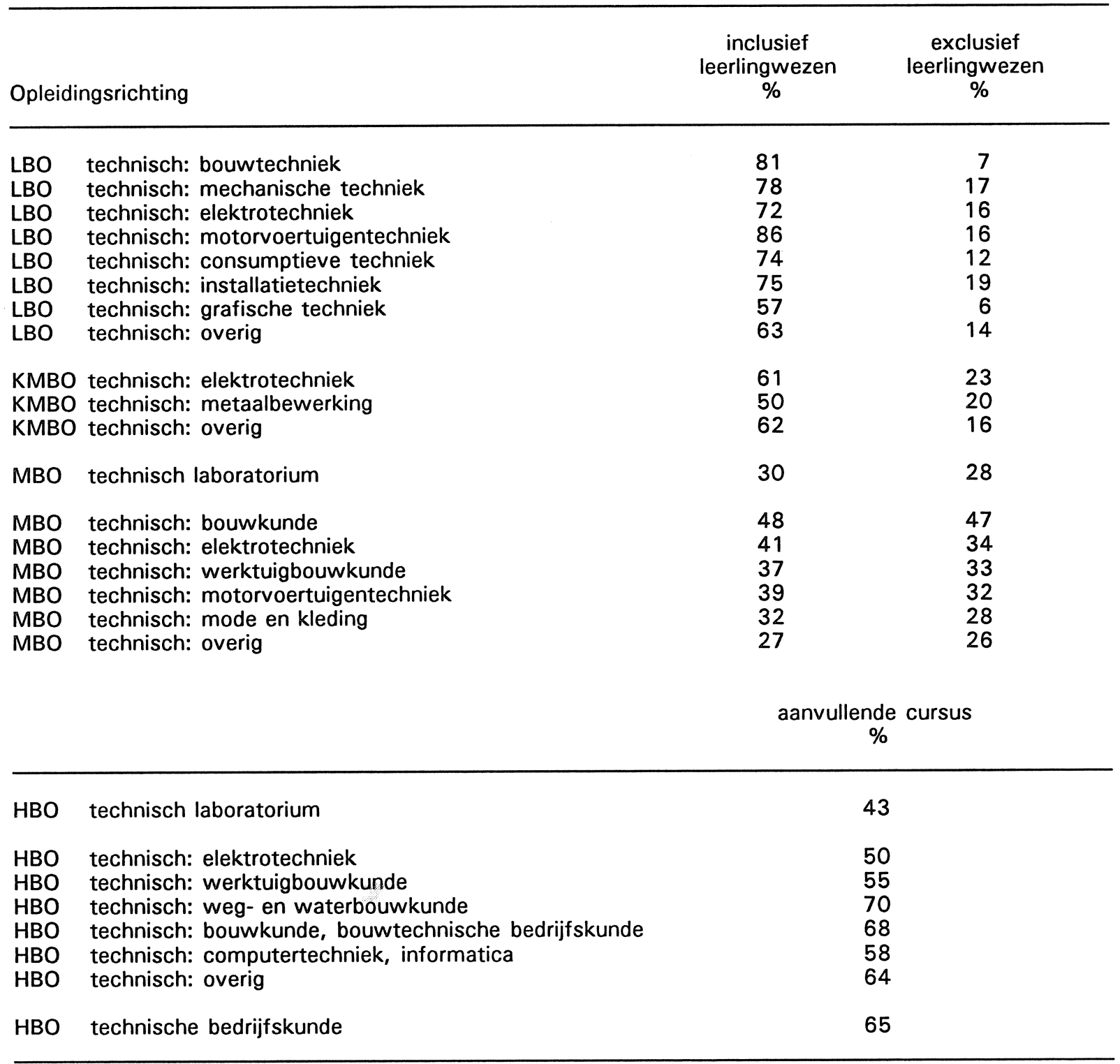

Bron: RUBS 1992/HBO-Monitor 1991/ROA 
De deelname aan aanvullende scholing kan eveneens een indicatie vormen voor de kwaliteit van het werk dat door de schoolverlaters wordt uitgeoefend ongeveer een jaar na het verlaten van de opleiding. Een hoge deelname aan aanvullende opleidingen wijst op veel doorgroeimogelijkheden van de schoolverlaters met de desbetreffende opleidingsachtergrond (zie De Grip, Groot, Heijke en Willems, 1990) ${ }^{19}$. In tabel 3.7 wordt een beeld gegeven van de beschikbare informatie omtrent de cursussen en opleidingen die de werkende schoolverlaters volgen ten tijde van de meting. In de RUBS-vragenlijst is een aparte vraag opgenomen die informeert naar het feit of de gediplomeerden op het moment van de meting een opleiding in het leerlingwezen of in-service onderwijs volgen. Daarnaast is er een meer algemene vraag opgenomen die ingaat op aanvullende scholing en cursussen die niet tot het reguliere vervolgonderwijs behoren. In tabel 3.7 is bij de opleidingsrichtingen die in het RUBS-project zijn opgenomen enerzijds het percentage schoolverlaters dat een aanvullende opleiding of cursus volgt ten tijde van de meting gepresenteerd, waarbij een opleiding in het leerlingwezen of in-service onderwijs wordt meegerekend en anderzijds het percentage dat een aanvullende opleiding of cursus volgt exclusief degenen die een opleiding in het leerlingwezen of in-service onderwijs volgen.

Overigens kan in het RUBS-onderzoek geen verdere indicatie worden gegeven van het niveau en de richting van het aanvullend onderwijs. Op basis van de HBO-Monitor kan wel het type aanvullend onderwijs worden aangegeven (zie tabel 3.8). Het zou wenselijk zijn als zowel in het RUBS-onderzoek als in de HBO-Monitor informatie over het niveau en de richting van het aanvullend onderwijs zou worden getypeerd.

Tabel 3.8. Soort aanvullende cursussen en deeltijd opleidingen per opleidingsrichting (gediplomeerde HBO-schoolverlaters)

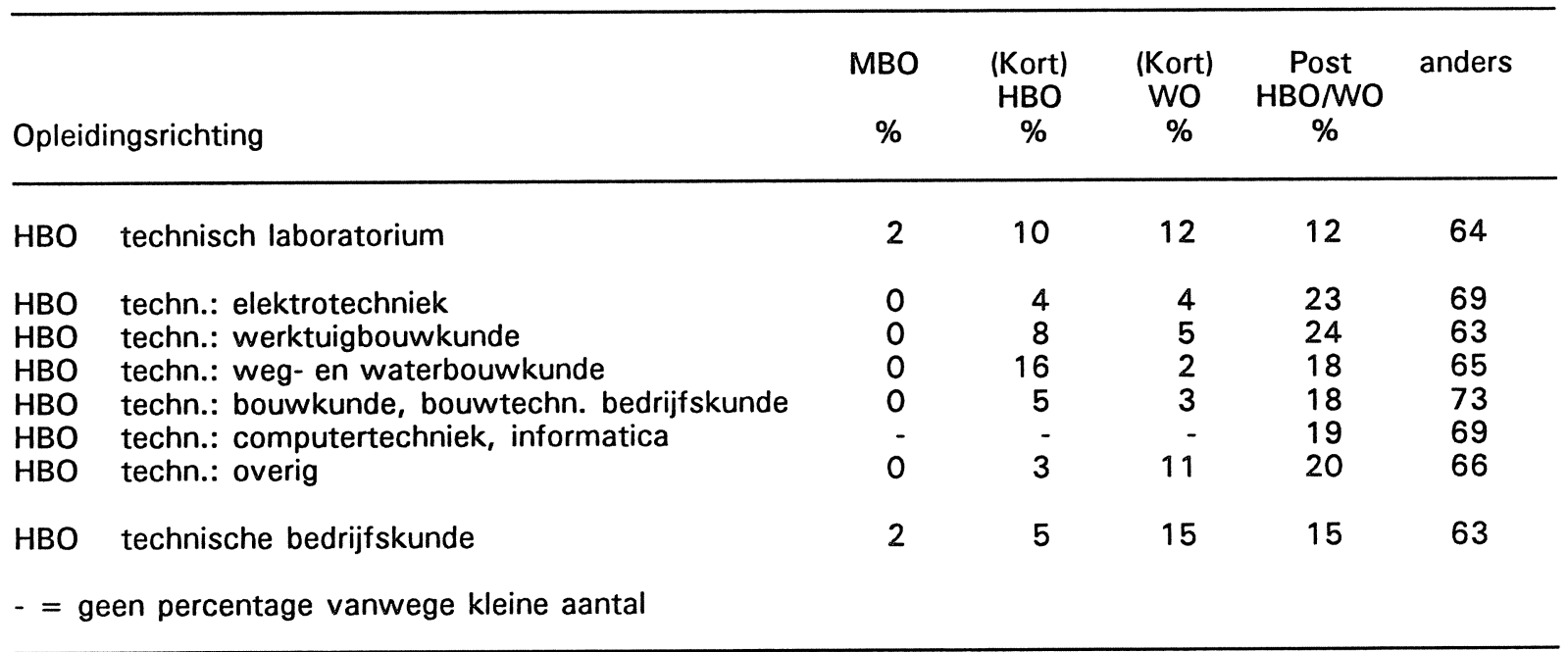

Bron: HBO-Monitor 1991/ROA

In het informatiesysteem onderwijs-arbeidsmarkt wordt als informatie over het soort baan

19. Ook kan het volgen van aanvullende scholing nodig zijn voor het goed kunnen uitoefenen van de huidige of toekomstige werkzaamheden. Aanvullend 'volwassenen onderwijs' is in dit geval een instrument om de aansluiting tussen de door de schoolverlaters gevolgde opleiding en de beroepspraktijk te verbeteren. 
waarin de werkzame personen werkzaam zijn het percentage zelfstandigen en het percentage dat in deeltijd werkt opgenomen. Deze informatie kan eveneens voor de schoolverlaters worden opgesteld. Let wel dat dit per opleidingsrichting wordt bepaald en niet, zoals tot op heden is gebeurd, per beroepsgroep. In tabel 3.9 wordt het percentage zelfstandigen per opleidingsrichting gepresenteerd. Tevens wordt aangegeven hoe groot het aandeel schoolverlaters is dat in loondienst werkt. In de laatste kolom staat het percentage van de in loondienst werkende schoolverlaters dat een vaste aanstelling heeft. Met name deze laatste indicator kan een aanvullend beeld geven over de arbeidszekerheid.

Tabel 3.9. Soort aanstelling per opleidingsrichting (gediplomeerde schoolverlaters)

\begin{tabular}{|c|c|c|c|c|}
\hline LBO & technisch: bouwtechniek & 1 & 99 & 17 \\
\hline LBO & technisch: mechanische techniek & 1 & 99 & 20 \\
\hline LBO & technisch: elektrotechniek & 1 & 98 & 19 \\
\hline LBO & technisch: motorvoertuigentechniek & 2 & 97 & 13 \\
\hline LBO & technisch: consumptieve techniek & 3 & 97 & 18 \\
\hline LBO & technisch: installatietechniek & 0 & 100 & 22 \\
\hline LBO & technisch: grafische techniek & 3 & 97 & 29 \\
\hline LBO & technisch: overig & 1 & 98 & 35 \\
\hline KMBO & technisch: elektrotechniek & 2 & 97 & 30 \\
\hline KMBO & technisch: metaalbewerking & 0 & 100 & 52 \\
\hline KMBO & technisch: overig & 2 & 98 & 34 \\
\hline MBO & technisch laboratorium & 0 & 99 & 55 \\
\hline MBO & technisch: bouwkunde & 5 & 95 & 77 \\
\hline MBO & technisch: elektrotechniek & 2 & 96 & 62 \\
\hline MBO & technisch: werktuigbouwkunde & 4 & 95 & 71 \\
\hline MBO & technisch: motorvoertuigentechniek & 8 & 90 & - \\
\hline MBO & technisch: mode en kleding & 2 & 96 & 86 \\
\hline MBO & technisch: overig & 5 & 93 & 82 \\
\hline HBO & technisch laboratorium & 0 & 100 & 58 \\
\hline HBO & technisch: elektrotechniek & 0 & 100 & 77 \\
\hline HBO & technisch: werktuigbouwkunde & 0 & 100 & 70 \\
\hline HBO & technisch: weg- en waterbouwkunde & 1 & 99 & 64 \\
\hline HBO & technisch: bouwkunde, bouwtechn. bedrijfskunde & 1 & 99 & 80 \\
\hline HBO & technisch: computertechniek, informatica & 3 & 97 & 83 \\
\hline HBO & technisch: overig & 3 & 97 & 78 \\
\hline HBO & technische bedrijfskunde & 1 & 99 & 75 \\
\hline
\end{tabular}

Bron: RUBS 1992/HBO-Monitor 1991/ROA

Ten aanzien van de gegevens die in tabel 3.9 worden gepresenteerd moet worden opgemerkt dat de vraagstelling in beide enquêtes afwijkt, hetgeen de vergelijking van de waarden van de indicatoren mogelijk enigszins vertekent. In de RUBS-vragenlijst is een vraag opgenomen waaruit zowel het percentage schoolverlaters dat in loondienst werkt kan worden afgeleid, als 
het percentage in loondienst werkende schoolverlaters dat een vaste baan heeft. In de vragenlijst voor de HBO-Monitor is eerst een vraag opgenomen waaruit het percentage afgestudeerden dat in loondienst of als zelfstandige werkzaam is kan worden bepaald. In een volgende vraag wordt het onderscheid tussen een vaste en tijdelijke baan gemaakt. In de vragenlijst van RUBS 1993 is hiermee echter rekening gehouden en is een betere afstemming op de vragenlijst van de HBO-Monitor bewerkstelligd. Daarbij is het van belang de categorieën zoveel mogelijk op elkaar te laten aansluiten. Dit heeft bijvoorbeeld tot gevolg dat in beide schoolverlatersbestanden de mensen die een baan met een nul-uren contract of een oproepbaan hebben tot de in loondienst werkende schoolverlaters worden gerekend. Momenteel onderzoekt het CBS op welke wijze de werkkring (loondienst of zelfstandig) van de werkzame personen het beste kan worden gedefinieerd. Eventuele veranderingen in de typering en vraagstelling zullen in de schoolverlatersenquêtes worden overgenomen.

Tabel 3.10. Wekelijkse arbeidsduur per opleidingsrichting (gediplomeerde schoolverlaters)

\section{Opleidingsrichting}

part-time

$\%$

$\begin{array}{llr}\text { LBO } & \text { technisch: bouwtechniek } & 77 \\ \text { LBO } & \text { technisch: mechanische techniek } & 62 \\ \text { LBO } & \text { technisch: elektrotechniek } & 70 \\ \text { LBO } & \text { technisch: motorvoertuigentechniek } & 77 \\ \text { LBO } & \text { technisch: consumptieve techniek } & 79 \\ \text { LBO } & \text { technisch: installatietechniek } & 68 \\ \text { LBO } & \text { technisch: grafische techniek } & 35 \\ \text { LBO } & \text { technisch: overig } & 58 \\ & & \\ \text { KMBO technisch: elektrotechniek } & 48 \\ \text { KMBO technisch: metaalbewerking } & 20 \\ \text { KMBO technisch: overig } & 46 \\ & & 8 \\ \text { MBO } & \text { technisch laboratorium } & 8 \\ & & 13 \\ \text { MBO } & \text { technisch: bouwkunde } & 11 \\ \text { MBO } & \text { technisch: elektrotechniek } & 13 \\ \text { MBO } & \text { technisch: werktuigbouwkunde } & 29 \\ \text { MBO } & \text { technisch: motorvoertuigentechniek } & 12 \\ \text { MBO } & \text { technisch: mode en kleding } & \\ \text { MBO } & \text { technisch: overig } & 5 \\ & & \\ \text { HBO } & \text { technisch laboratorium } & 1 \\ & & 3 \\ \text { HBO } & \text { technisch: elektrotechniek } & 1 \\ \text { HBO } & \text { technisch: werktuigbouwkunde } & 1 \\ \text { HBO } & \text { technisch: weg- en waterbouwkunde } & 0 \\ \text { HBO } & \text { technisch: bouwkunde, bouwtechnische bedrijfskunde } & 0 \\ \text { HBO } & \text { technisch: computertechniek, informatica } & 4 \\ \text { HBO } & \text { technisch: overig } & \\ & & \\ \text { HBO } & \text { technische bedrijfskunde } & \\ & & \end{array}$

Bron: RUBS 1992/HBO-Monitor 1991/ROA

In het informatiesysteem werden tot op heden de werkzame personen die een baan van minder 
dan 30 uur per week hebben tot de deeltijd werkers gerekend. In de toekomst zal ook in het informatiesysteem worden gestreefd deze urengrens te verhogen, zodat degenen die 32 uur of minder per week werken tot de in deeltijd werkenden worden gerekend. Deze urengrens is in tabel 3.10 reeds gehanteerd. Met name van de LBO-schoolverlaters blijkt een hoog percentage in deeltijd te werken. Bij nadere analyse blijkt dat het merendeel van deze schoolverlaters 32 uur per week werkt. Deze hoge percentages voor de gediplomeerden van het LBO zijn te danken aan het feit dat een groot deel van deze schoolverlaters na het verlaten van de LBO-opleiding een opleiding in het leerlingwezen of in-service onderwijs gaat volgen.

Tabel 3.11. Grootte van de organisatie waarin de schoolverlaters werkzaam zijn Igediplomeerde schoolverlaters)

\begin{tabular}{|c|c|c|c|c|c|}
\hline Opleidi & ingsrichting & $\begin{array}{c}1-9 \\
\text { personen } \\
\%\end{array}$ & $\begin{array}{c}10-49 \\
\text { personen } \\
\%\end{array}$ & $\begin{array}{c}50-99 \\
\text { personen } \\
\%\end{array}$ & $\begin{array}{c}>100 \\
\text { personen } \\
\%\end{array}$ \\
\hline $\begin{array}{l}\text { LBO } \\
\text { LBO } \\
\text { LBO } \\
\text { LBO } \\
\text { LBO } \\
\text { LBO } \\
\text { LBO } \\
\text { LBO }\end{array}$ & $\begin{array}{l}\text { techn.: bouwtechniek } \\
\text { techn.: mechanische techniek } \\
\text { techn.: elektrotechniek } \\
\text { techn.: motorvoertuigentechniek } \\
\text { techn.: consumptieve techniek } \\
\text { techn.: installatietechniek } \\
\text { techn.: grafische techniek } \\
\text { techn.: overig }\end{array}$ & $\begin{array}{l}32 \\
27 \\
23 \\
43 \\
43 \\
20 \\
38 \\
42\end{array}$ & $\begin{array}{l}43 \\
37 \\
34 \\
42 \\
45 \\
55 \\
48 \\
35\end{array}$ & $\begin{array}{r}10 \\
15 \\
17 \\
7 \\
5 \\
13 \\
5 \\
14\end{array}$ & $\begin{array}{r}15 \\
21 \\
26 \\
7 \\
7 \\
12 \\
10 \\
9\end{array}$ \\
\hline $\begin{array}{l}\text { KMBO } \\
\text { KMBO } \\
\text { KMBO }\end{array}$ & $\begin{array}{l}\text { techn.: elektrotechniek } \\
\text { techn.: metaalbewerking } \\
\text { techn.: overig }\end{array}$ & $\begin{array}{l}18 \\
16 \\
40\end{array}$ & $\begin{array}{l}36 \\
40 \\
41\end{array}$ & $\begin{array}{r}13 \\
15 \\
5\end{array}$ & $\begin{array}{l}33 \\
29 \\
15\end{array}$ \\
\hline MBO & technisch laboratorium & 10 & 27 & 11 & 52 \\
\hline $\begin{array}{l}\text { MBO } \\
\text { MBO } \\
\text { MBO } \\
\text { MBO } \\
\text { MBO } \\
\text { MBO }\end{array}$ & $\begin{array}{l}\text { techn.: bouwkunde } \\
\text { techn.: elektrotechniek } \\
\text { techn.: werktuigbouwkunde } \\
\text { techn.: motorvoertuigentechniek } \\
\text { techn.: mode en kleding } \\
\text { techn.: overig }\end{array}$ & $\begin{array}{l}14 \\
16 \\
19 \\
26 \\
47 \\
32\end{array}$ & $\begin{array}{l}37 \\
30 \\
36 \\
38 \\
30 \\
35\end{array}$ & $\begin{array}{r}16 \\
10 \\
12 \\
12 \\
7 \\
11\end{array}$ & $\begin{array}{l}33 \\
44 \\
32 \\
24 \\
16 \\
22\end{array}$ \\
\hline $\mathrm{HBO}$ & technisch laboratorium & 3 & 20 & 6 & 71 \\
\hline $\begin{array}{l}\text { HBO } \\
\text { HBO } \\
\text { HBO } \\
\text { HBO } \\
\text { HBO } \\
\text { HBO }\end{array}$ & $\begin{array}{l}\text { techn.: elektrotechniek } \\
\text { techn.: werktuigbouwkunde } \\
\text { techn.: weg- en waterbouwkunde } \\
\text { techn.: bouwkunde, bouwtechn. bedrijfskunde } \\
\text { techn.: computertechniek, informatica } \\
\text { techn.: overig }\end{array}$ & $\begin{array}{r}10 \\
7 \\
9 \\
19 \\
5 \\
6\end{array}$ & $\begin{array}{l}20 \\
24 \\
34 \\
43 \\
21 \\
16\end{array}$ & $\begin{array}{r}9 \\
16 \\
11 \\
16 \\
10 \\
13\end{array}$ & $\begin{array}{l}61 \\
54 \\
47 \\
23 \\
65 \\
66\end{array}$ \\
\hline $\mathrm{HBO}$ & technische bedrijfskunde & 11 & 21 & 10 & 59 \\
\hline
\end{tabular}

Bron: RUBS 1992/HBO-Monitor 1991/ROA

Als een nieuw en aanvullend gegeven kan uit de twee schoolverlatersbestanden informatie worden verkregen over de grootte van de organisatie waarin de schoolverlaters werkzaam zijn. Deze informatie staat in tabel 3.11. Daarbij moet worden opgemerkt dat de vraagstelling in beide enquêtes niet geheel op elkaar aansluit. In de HBO-vragenlijst wordt expliciet gevraagd 
naar de vestiging van het bedrijf of de instelling waar de schoolverlaters werken, terwijl de RUBS-vragenlijst naar de grootte van de organisatie vraagt. Bij de nieuwe vragenlijsten heeft echter reeds een goede afstemming plaatsgevonden tussen de vragenlijsten van het RUBS- en HBO-project.

Tabel 3.12. Percentage leidinggevenden per opleidingsrichting (gediplomeerde HBO-schoolverlaters)

\begin{tabular}{|c|c|c|c|}
\hline \multicolumn{2}{|c|}{ Opleidingsrichting } & $\begin{array}{c}\text { leiding aan } \\
1-4 \text { personen } \\
\%\end{array}$ & $\begin{array}{c}\text { leiding aan } \\
\geq 5 \text { personen } \\
\%\end{array}$ \\
\hline HBO & technisch laboratorium & 15 & 3 \\
\hline $\begin{array}{l}\text { HBO } \\
\text { HBO } \\
\text { HBO } \\
\text { HBO } \\
\text { HBO } \\
\text { HBO }\end{array}$ & $\begin{array}{l}\text { technisch: elektrotechniek } \\
\text { technisch: werktuigbouwkunde } \\
\text { technisch: weg-en waterbouwkunde } \\
\text { technisch: bouwkunde, bouwtechnische bedrijfskunde } \\
\text { technisch: computertechniek, informatica } \\
\text { technisch: overig }\end{array}$ & $\begin{array}{l}16 \\
18 \\
18 \\
16 \\
16 \\
20\end{array}$ & $\begin{array}{r}9 \\
11 \\
17 \\
18 \\
2 \\
13\end{array}$ \\
\hline $\mathrm{HBO}$ & technische bedrijfskunde & 18 & 20 \\
\hline
\end{tabular}

Bron: HBO-Monitor 1991/ROA

Als laatste aanvullende actuele indicator wordt in tabel 3.12 voor de HBO-opleidingen het percentage leidinggevenden per opleidingsrichting gepresenteerd. Deze vraag is slechts in de vragenlijst van de HBO-Monitor opgenomen en derhalve ontbreekt informatie voor de lagere niveaus. Wellicht is het niet zo zinvol deze informatie ook voor schoolverlaters op LBO- en MBOniveau te genereren.

\subsection{Risico-indicatoren}

$\mathrm{Na}$ de in de vorige paragraaf besproken actuele indicatoren wordt in deze paragraaf ingegaan op enkele risico-indicatoren. Deze indicatoren belichten een aantal doorgaans meer stabiele kenmerken van het arbeidsmarktsegment waarop men opereert. De conjunctuurgevoeligheid van een opleiding geeft daarbij aan hoe stabiel de werkgelegenheidssituatie is in het segment waarvoor wordt opgeleid. Een hoge conjunctuurgevoeligheid betekent dat de omvang van de werkgelegenheid sterk aan fluctuaties onderhevig is. De beroepenspreiding geeft aan in hoeverre schoolverlaters afhankelijk zijn van de werkgelegenheidsontwikkeling binnen één segment, en in hoeverre er uitwijkmogelijkheden zijn naar andere beroepen (zie ook De Grip, Van der Velden en Wieling, 1993).

In de afzonderlijke bedrijfssectoren is de reactie van de werkgelegenheid op conjunctuurschommelingen in het verleden nogal verschillend geweest. Om na te gaan of de huidige werkgelegenheidssituatie van tijdelijke of meer permanente aard is, is de conjunctuurgevoeligheid van de werkgelegenheid berekend. De conjunctuurgevoeligheid geeft een beeld van de mate van werkzekerheid van de werkgelegenheid in de sectoren waar de schoolverlaters met een bepaalde opleidingsachtergrond terechtkomen. Daarvoor wordt eerst een fluctuatie-index 
per bedrijfssector berekend. Vervolgens worden uit deze fluctuatie-indices voor bedrijfssectoren, fluctuatie-indices voor de verschillende opleidingsrichtingen afgeleid, door de indices van de sectoren te wegen met de aandelen van de sectoren in de totale werkgelegenheid van de desbetreffende opleidingsrichting. Daarbij wordt verondersteld dat de werkgelegenheid van de verschillende opleidingsrichtingen binnen een bedrijfstak in gelijke mate fluctueert (zie Wieling, De Grip en Van der Velden, 1992).

Tabel 3.13. Conjunctuurgevoeligheid per opleidingsrichting (gediplomeerde schoolverlaters)

\begin{tabular}{|c|c|c|}
\hline $\begin{array}{l}\text { LBO } \\
\text { LBO } \\
\text { LBO } \\
\text { LBO } \\
\text { LBO } \\
\text { LBO } \\
\text { LBO } \\
\text { LBO }\end{array}$ & $\begin{array}{l}\text { technisch: bouwtechniek } \\
\text { technisch: mechanische techniek } \\
\text { technisch: elektrotechniek } \\
\text { technisch: motorvoertuigentechniek } \\
\text { technisch: consumptieve techniek } \\
\text { technisch: installatietechniek } \\
\text { technisch: grafische techniek } \\
\text { technisch: overig }\end{array}$ & $\begin{array}{l}3,02 \\
2,17 \\
2,68 \\
1,50 \\
1,39 \\
3,11 \\
1,75 \\
1,77\end{array}$ \\
\hline $\begin{array}{l}\text { KMBO } \\
\text { KMBO } \\
\text { KMBO }\end{array}$ & $\begin{array}{l}\text { technisch: elektrotechniek } \\
\text { technisch: metaalbewerking } \\
\text { technisch: overig }\end{array}$ & $\begin{array}{l}2,86 \\
2,46 \\
2,30\end{array}$ \\
\hline MBO & technisch laboratorium & 1,77 \\
\hline $\begin{array}{l}\text { MBO } \\
\text { MBO } \\
\text { MBO } \\
\text { MBO } \\
\text { MBO } \\
\text { MBO }\end{array}$ & $\begin{array}{l}\text { technisch: bouwkunde } \\
\text { technisch: elektrotechniek } \\
\text { technisch: werktuigbouwkunde } \\
\text { technisch: motorvoertuigentechniek } \\
\text { technisch: mode en kleding } \\
\text { technisch: overig }\end{array}$ & $\begin{array}{l}2,50 \\
2,33 \\
2,15 \\
1,68 \\
1,66 \\
1,82\end{array}$ \\
\hline HBO & technisch laboratorium & 1,67 \\
\hline $\begin{array}{l}\text { HBO } \\
\text { HBO } \\
\text { HBO } \\
\text { HBO } \\
\text { HBO } \\
\text { HBO }\end{array}$ & $\begin{array}{l}\text { technisch: elektrotechniek } \\
\text { technisch: werktuigbouwkunde } \\
\text { technisch: weg- en waterbouwkunde } \\
\text { technisch: bouwkunde, bouwtechnische bedrijfskunde } \\
\text { technisch: computertechniek, informatica } \\
\text { technisch: overig }\end{array}$ & $\begin{array}{l}1,82 \\
2,07 \\
2,09 \\
2,19 \\
1,70 \\
1,87\end{array}$ \\
\hline $\mathrm{HBO}$ & technische bedrijfskunde & 1,90 \\
\hline
\end{tabular}

Bron: RUBS 1992/HBO-Monitor 1991/ROA

De conjunctuurindicator is van belang bij het beoordelen van de fluctuaties die er kunnen optreden in de omvang van de werkgelegenheid. Bij sterk conjunctuurgevoelige opleidingsrichtingen moet rekening worden gehouden met een onzekere werkgelegenheidssituatie op langere termijn. Dit kan betekenen dat de kansen op (behoud van het) werk, zoals dat onder meer tot uitdrukking komt in het werkloosheidspercentage, door de jaren heen sterk kan fluctueren. Op basis van de schoolverlatersdata kan nu worden nagegaan of de schoolverlaters in sterk conjunctuurgevoelige segmenten van de arbeidsmarkt terechtkomen of dat zij in meer stabiele sectoren komen te werken. Tabel 3.13 geeft hiervan een indruk. Hierbij valt met name op dat het van belang is de conjunctuurindicator op een relatief laag aggregatieniveau te 
bepalen, getuige de grote variatie in deze indicatoren tussen de verschillende opleidingsrichtingen binnen één opleidingstype.

Tabel 3.14. Beroepsgroepenspreiding per opleidingsrichting (gediplomeerde schoolverlaters)

\begin{tabular}{|c|c|c|c|c|}
\hline \multicolumn{2}{|c|}{ Opleidingsrichting } & \multirow{2}{*}{$\begin{array}{c}\begin{array}{c}\text { alle } \\
\text { beroepen }\end{array} \\
\\
\\
\\
0,68 \\
0,94 \\
0,80 \\
0,68 \\
0,74 \\
0,63 \\
0,82 \\
0,87\end{array}$} & \multirow{2}{*}{$\begin{array}{c}\begin{array}{c}\text { beroepen op } \\
\text { aansluitend } \\
\text { niveau } \\
\text { Huijgen }\end{array} \\
0,58 \\
0,90 \\
0,59 \\
0,45 \\
0,57 \\
0,57 \\
0,68 \\
0,89\end{array}$} & \multirow{2}{*}{$\begin{array}{c}\begin{array}{c}\text { beroepen op } \\
\text { aansluitend } \\
\text { niveau } \\
\text { vereist niveau }\end{array} \\
0,63 \\
0,94 \\
0,72 \\
0,62 \\
0,67 \\
0,58 \\
0,72 \\
0,86\end{array}$} \\
\hline $\begin{array}{l}\text { LBO } \\
\text { LBO } \\
\text { LBO } \\
\text { LBO } \\
\text { LBO } \\
\text { LBO } \\
\text { LBO } \\
\text { LBO }\end{array}$ & $\begin{array}{l}\text { techn.: bouwtechniek } \\
\text { techn.: mechanische techniek } \\
\text { techn.: elektrotechniek } \\
\text { techn.: motorvoertuigentechniek } \\
\text { techn.: consumptieve techniek } \\
\text { techn.: installatietechniek } \\
\text { techn.: grafische techniek } \\
\text { techn.: overig }\end{array}$ & & & \\
\hline $\begin{array}{l}\text { KMBO } \\
\text { KMBO } \\
\text { KMBO }\end{array}$ & $\begin{array}{l}\text { techn.: elektrotechniek } \\
\text { techn.: metaalbewerking } \\
\text { techn.: overig }\end{array}$ & $\begin{array}{l}0,78 \\
0,90 \\
0,93\end{array}$ & $\begin{array}{l}0,51 \\
0,84 \\
0,80\end{array}$ & $\begin{array}{l}0,69 \\
0,88 \\
0,91\end{array}$ \\
\hline MBO & technisch laboratorium & 0,51 & 0,47 & 0,41 \\
\hline $\begin{array}{l}\text { MBO } \\
\text { MBO } \\
\text { MBO } \\
\text { MBO } \\
\text { MBO } \\
\text { MBO }\end{array}$ & $\begin{array}{l}\text { techn.: bouwkunde } \\
\text { techn.: elektrotechniek } \\
\text { techn.: werktuigbouwkunde } \\
\text { techn.: motorvoertuigentechniek } \\
\text { techn.: mode en kleding } \\
\text { techn.: overig }\end{array}$ & $\begin{array}{l}0,81 \\
0,86 \\
0,93 \\
0,84 \\
0,74 \\
0,93\end{array}$ & $\begin{array}{l}0,75 \\
0,80 \\
0,87 \\
0,75 \\
0,87 \\
0,91\end{array}$ & $\begin{array}{l}0,78 \\
0,86 \\
0,89 \\
0,83 \\
0,74 \\
0,93\end{array}$ \\
\hline $\mathrm{HBO}$ & technisch laboratorium & 0,72 & 0,70 & 0,72 \\
\hline $\begin{array}{l}\text { HBO } \\
\text { HBO } \\
\text { HBO } \\
\text { HBO } \\
\text { HBO } \\
\text { HBO }\end{array}$ & $\begin{array}{l}\text { techn.: elektrotechniek } \\
\text { techn.: werktuigbouwkunde } \\
\text { techn.: weg-en waterbouwkunde } \\
\text { techn.: bouwkunde, bouwtechn. bedrijfskunde } \\
\text { techn.: computertechniek, informatica } \\
\text { techn.: overig }\end{array}$ & $\begin{array}{l}0,69 \\
0,91 \\
0,65 \\
0,76 \\
0,45 \\
0,93\end{array}$ & $\begin{array}{l}0,65 \\
0,88 \\
0,62 \\
0,76 \\
0,41 \\
0,90\end{array}$ & $\begin{array}{l}0,68 \\
0,90 \\
0,66 \\
0,78 \\
0,44 \\
0,92\end{array}$ \\
\hline $\mathrm{HBO}$ & technische bedrijfskunde & 0,93 & 0,89 & 0,92 \\
\hline
\end{tabular}

Bron: RUBS 1992/HBO-Monitor 1991/ROA

De indicator van de beroepenspreiding maakt het mogelijk om na te gaan of er een exclusieve relatie bestaat tussen een opleiding en een bepaald beroep (naïeve model) of dat er enige flexibiliteit in de aansluiting tussen enerzijds opleidingen en anderzijds beroepen en branches aanwezig is (Van Hoof en Dronkers, 1980). Met behulp van flexibiliteitsindicatoren kunnen de uitwijkmogelijkheden die men heeft, wanneer men kiest voor een bepaald opleidingstype, worden aangegeven. Bovendien geven deze indicatoren een indruk van de mate waarin men zich met de keuze van een studie of beroep vastlegt voor een specifieke loopbaan. Op basis van de Gini-Hirschman coëfficiënt ${ }^{20}$ wordt de beroepenspreiding van de verschillende

20. In de oorspronkelijke Gini-Hirschman coëfficiënt wordt een correctiefactor opgenomen om te corrigeren voor het gehanteerde aggregatieniveau. Deze correctieterm is hier echter weggelaten, vanwege het feit dat de correctieterm bijna gelijk is aan 1 bij een zo groot aantal beroepsgroepen, als op 3-digit niveau wordt onderscheiden. 
opleidingscategorieën bepaald (Sheldon, 1985 en Warnken, 1986) ${ }^{21}$. Het grote voordeel van deze indicator is dat hij zeer makkelijk is te interpreteren. De indicator neemt waarden aan tussen 0 en 1 . De beroepenspreiding van opleidingen is 0 als de opleiding slechts in én beroep voorkomt en 1 als de opleiding gelijkmatig over alle beroepen is verspreid. Hetzelfde geldt voor de branchespreiding.

Tabel 3.15. Bedrijfsklassenspreiding per opleidingsrichting (gediplomeerde schoolverlaters)

\begin{tabular}{lll} 
LBO & technisch: bouwtechniek & 0,52 \\
LBO & technisch: mechanische techniek & 0,91 \\
LBO & technisch: elektrotechniek & 0,78 \\
LBO & technisch: motorvoertuigentechniek & 0,67 \\
LBO & technisch: consumptieve techniek & 0,64 \\
LBO & technisch: installatietechniek & 0,45 \\
LBO & technisch: grafische techniek & 0,58 \\
LBO & technisch: overig & 0,78 \\
& & \\
KMBO & technisch: elektrotechniek & 0,79 \\
KMBO technisch: metaalbewerking & 0,87 \\
KMBO technisch: overig & 0,87 \\
& & \\
MBO & technisch laboratorium & 0,86 \\
& & \\
MBO & technisch: bouwkunde & 0,73 \\
MBO & technisch: elektrotechniek & 0,89 \\
MBO & technisch: werktuigbouwkunde & 0,91 \\
MBO & technisch: motorvoertuigentechniek & 0,81 \\
MBO & technisch: mode en kleding & 0,62 \\
MBO & technisch: overig & 0,87 \\
& & \\
HBO & technisch laboratorium & 0,84 \\
& & \\
HBO & technisch: elektrotechniek & 0,85 \\
HBO & technisch: werktuigbouwkunde & 0,87 \\
HBO & technisch: weg- en waterbouwkunde & 0,71 \\
HBO & technisch: bouwkunde, bouwtechnische bedrijfskunde & 0,67 \\
HBO & technisch: computertechniek, informatica & 0,78 \\
HBO & technisch: overig & 0,92 \\
HBO & technische bedrijfskunde & 0,93 \\
& & \\
\hline
\end{tabular}

Bron: RUBS 1992/HBO-Monitor 1991/ROA

In de eerste kolom van tabel 3.14 wordt per opleidingsrichting de beroepsgroepenspreiding weergegeven. In deze tabel wordt in de laatste twee kolommen de beroepsgroepenspreiding gepresenteerd, waarbij rekening wordt gehouden met het vereiste opleidingsniveau. Dat wil zeggen dat bij het bepalen van de Gini-Hirschman coëfficiënt alleen de schoolverlaters worden meegenomen waarvoor het opleidingsniveau dat vereist is voor de baan die ze op het moment van de meting uitoefenen niet lager is dan het niveau van de opleiding die ze met succes hebben afgesloten. De middelste kolom geeft de beroepsgroepenspreiding die is bepaald op

21. Overigens moet worden bedacht dat de hier weergegeven spreidingsindicatoren niet betrekking hebben op de potentiële flexibiliteit, maar op de feitelijk opgetreden flexibiliteit (De Grip en Heijke, 1989). 
basis van de functieniveau-indeling van Huijgen, terwijl bij de indicator van de beroepsgroepenspreiding op aansluitend niveau, zoals vermeld in de laatste kolom, gebruik is gemaakt van de vragen naar het vereiste opleidingsniveau zoals die in de beide enquêtes zijn opgenomen. Tabel 3.15 geeft de bedrijfsklassenspreiding per opleidingsrichting aan.

Het bepalen van de spreidingsindicatoren op basis van de schoolverlatersdata geniet veruit de voorkeur boven het bepalen van deze indicatoren op basis van de EBB-data. De schoolverlatersbestanden bieden namelijk de mogelijkheid de spreidingsindicatoren op een laag aggregatieniveau per opleidingsrichting te genereren, terwijl op basis van de EBB-data van opleidingstypen wordt uitgegaan. Door de mogelijkheid opleidingsrichting als invalshoek te kunnen kiezen, kunnen er meer nauwkeurige gegevens over de uitwijkmogelijkheden worden verkregen. Op deze wijze kan worden voorkomen dat een hoge branche- of beroepenspreiding louter het gevolg is van het feit dat wordt uitgegaan van een naar opleidingsrichtingen heterogeen opleidingstype, terwijl de spreiding voor de onderliggende opleidingsrichtingen in feite veel kleiner is.

Tabel 3.16. Vergelijking beroepsgroepenspreiding per opleidingstype en gemiddelde over de opleidingsrichtingen binnen éen opleidingstype op basis van de schoolverlatersdata

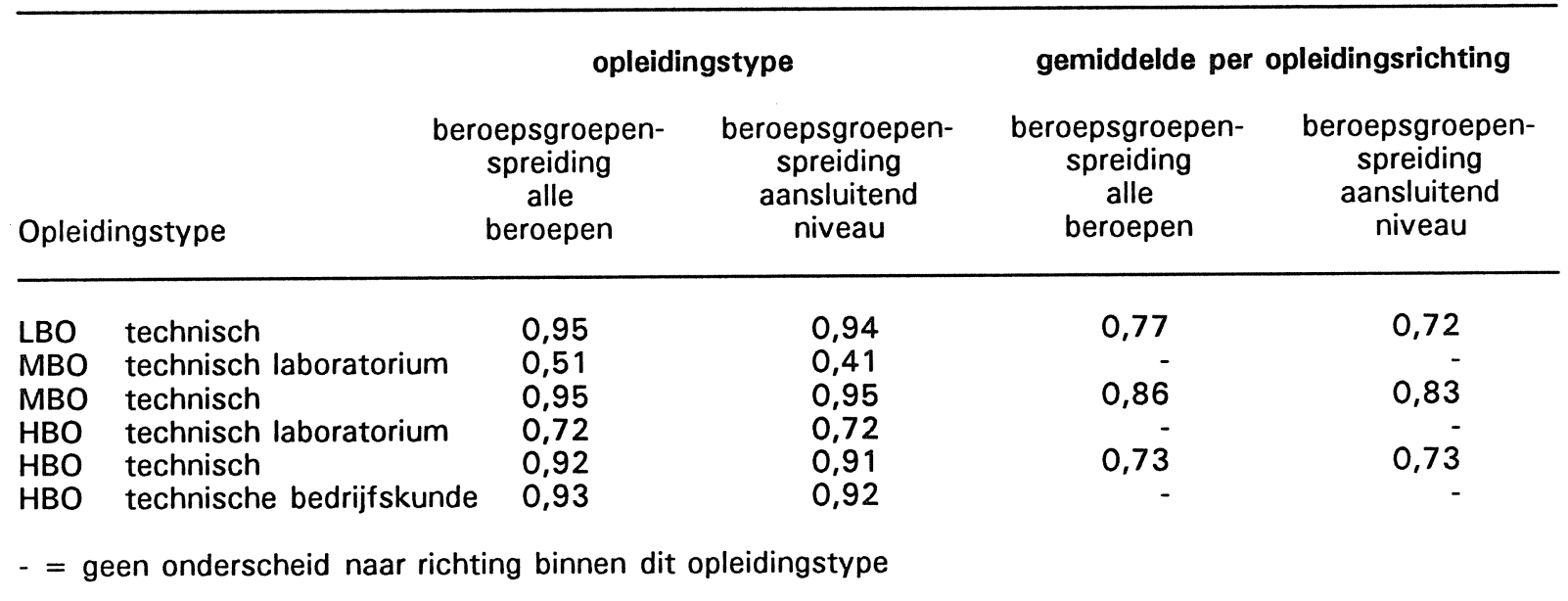

Bron: RUBS 1992/HBO-Monitor 1991/ROA

In tabel 3.16 wordt het verschil aangegeven tussen de hoogte van de spreidingsindicatoren zoals die op basis van de schoolverlatersdata per opleidingstype worden gegenereerd en de gemiddelde waarden van dezelfde spreidingsindicatoren indien die worden berekend op het meer verfijnde niveau van de verschillende opleidingsrichtingen. In de eerste twee kolommen worden respectievelijk de beroepsgroepenspreiding voor alle beroepen en de beroepsgroepenspreiding op aansluitend niveau voor de technische ROA-opleidingstypen gepresenteerd overeenkomstig de indicatoren die in het informatiesysteem zijn opgenomen. In de laatste twee kolommen wordt per opleidingstype het gemiddelde van de beroepsgroepenspreiding op basis van de onderliggende spreidingscoëfficiënten per opleidingsrichting weergegeven. Ook hier weer achtereenvolgens voor alle beroepen en alleen met betrekking tot de beroepen waarvan het vereiste functieniveau niet lager is dan het gevolgde niveau. Indien er meer opleidingsrichtingen behoren tot één opleidingstype, zijn de gemiddelde spreidingscoëfficiënten in alle gevallen lager 
dan de beroepenspreiding per opleidingstype. Dit duidt inderdaad op een overschatting van de uitwijkmogelijkheden bij de indicatoren die tot op heden in het informatiesysteem zijn opgenomen. Bij het vaststellen van de uitwijkmogelijkheden per opleidingstype op basis van een Gini-Hirschman coëfficiënt wordt namelijk verondersteld dat de uitwijkmogelijkheden bij alle onderliggende richtingen hetzelfde zijn. In feite kan er echter sprake zijn van opleidingsrichtingen binnen het opleidingstype die opleiden voor min of meer specifieke beroepen. De combinatie van dergelijke duidelijk van elkaar verschillende opleidingsrichtingen tot een opleidingstype leidt dan tot een vergroting van de waargenomen uitwijkmogelijkheden (zie Borghans, 1992).

Tot slot van dit hoofdstuk zal worden ingegaan op de mate waarin gediplomeerden van verschillende opleidingen elkaar beconcurreren op de arbeidsmarkt. In de praktijk verschillen sommige opleidingen veel van elkaar terwijl andere opleidingen meer op elkaar lijken (zie Van der Velden en Borghans, 1993). Bijvoorbeeld een economische opleiding op WO-niveau lijkt meer op een juridische opleiding op WO-niveau dan op een verzorgende opleiding op LBOniveau. Door eerst een vergelijking te maken van de beroepen waarin schoolverlaters terechtkomen, kan inzicht worden verkregen in de mate waarin de ene opleiding verschilt van de andere. Daarbij wordt nagegaan in welke mate de opleiding concurrentie ondervindt van andere opleidingen en welke opleidingen daarbij de belangrijkste concurrenten zijn (zie Van der Velden en Borghans, 1993). Deze concurrentie-index wordt in tabel 3 van bijlage II gepresenteerd. De concurrentie-index tussen twee opleidingen bedraagt 0 wanneer de beroepen waarin de afgestudeerden van de ene opleiding terechtkomen compleet verschillen van de beroepen bij de andere opleiding. De index is 1 wanneer de verdeling over beroepen van beide opleidingen precies gelijk is. In Borghans (1992) is op basis van deze concurrentie-index een maatstaf ontwikkeld om een correctie toe te passen op de Gini-Hirschman coëfficiënt, zodanig dat rekening wordt gehouden met de mate waarin opleidingen van elkaar verschillen. Voor een consistente maatstaf over de volle breedte van de arbeidsmarkt is echter informatie nodig over alle opleidingen. Daar er echter geen gegevens beschikbaar zijn over afgestudeerden van het WO is dit nog niet mogelijk.

Zoals reeds in de inleiding van dit hoofdstuk is opgemerkt, is het mogelijk om een kwalitatieve typering toe te kennen aan de hier gepresenteerde indicatoren. Met name bij de hier beschreven risico-indicatoren zal dit de interpretatie vergemakkelijken doordat de opleidingsrichtingen ten opzichte van elkaar worden gepositioneerd. 


\section{SAMENGESTELDE INDICATOREN}

\subsection{Inleiding}

In aansluitingsonderzoek wordt de arbeidsmarktpositie van schoolverlaters vaak getypeerd aan de hand van slechts een enkel kengetal, zoals het werkloosheidspercentage of het gemiddelde functieniveau ${ }^{22}$. Voor een evenwichtige beschouwing van de arbeidsmarktpositie van de schoolverlaters met een bepaalde opleidingsachtergrond is het evenwel van belang om gelijktijdig meerdere kernindicatoren in ogenschouw te nemen die de verschillende aspecten van de aansluiting tussen onderwijs en arbeidsmarkt belichten (zie ook De Grip, Van der Velden en Wieling, 1993). In dit hoofdstuk zal worden geprobeerd om verschillende van de in het vorige hoofdstuk gepresenteerde indicatoren, die informatie verschaffen over uiteenlopende aspecten van de arbeidsmarktpositie van schoolverlaters, op inzichtelijke wijze te combineren. Er zal een aantal zogenaamde 'samengestelde' indicatoren worden gepresenteerd die een afgewogen beeld geven van de initiële aansluiting tussen onderwijs en arbeidsmarkt. Achtereenvolgens wordt door middel van grafische weergaven de uiteenlopende aspecten van zowel de kans op en de kwaliteit van werk als de risicopositie van de schoolverlaters in brede zin nader bekeken (paragraaf 4.2) en worden samengestelde indicatoren ontwikkeld toegespitst op de eventuele mismatch in de directe aansluiting tussen onderwijs en arbeidsmarkt (paragraaf 4.3). Ten slotte zal in paragraaf 4.4 een beeld worden gegeven van de mogelijkheid om op individueel niveau informatie te genereren over de effecten van opleidingen op de arbeidsmarkt.

\subsection{Arbeidsmarktpositie van schoolverlaters grafisch weergegeven}

In deze paragraaf zullen door middel van grafische weergaven de uiteenlopende aspecten van de arbeidsmarktpositie van de schoolverlaters in brede zin nader worden belicht. Allereerst komt daarbij een aantal indicatoren aan de orde die inzicht geven in de actuele en risicopositie van de schoolverlaters. Vervolgens wordt aangegeven hoe de risico's op de arbeidsmarkt voor de verschillende opleidingsrichtingen in beeld kunnen worden gebracht.

Door gebruik te maken van pentagrammen en heptagrammen (zie Ministerie van Onderwijs en Wetenschappen en Ministerie van Economische Zaken, 1991) kan op een inzichtelijke wijze de marktpositie van schoolverlaters in beeld worden gebracht. Voor de pentagrammen is een vijftal indicatoren geselecteerd die de marktpositie van de gediplomeerde schoolverlaters in brede zin typeren. De verschillende onderliggende indicatoren zijn daarbij zodanig geformuleerd dat naarmate de waarde van de indicator hoger is, de arbeidsmarktpositie van de opleidingsrichting op het desbetreffende punt gunstiger is. Het gaat daarbij om de volgende vijf indicatoren:

- $\quad$ het percentage schoolverlaters dat niet werkloos is;

- de stabiliteit van de werkgelegenheid (conjunctuurindicator);

22. Zie bijvoorbeeld Teulings en Webbink (1990) die een indicator construeren voor de 'arbeidsmarktrelevantie' van opleidingen en daarbij slechts uitgaan van een enkele indicator (de werkloosheidsduur). 
- de uitwijkmogelijkheden naar andere beroepen;

- $\quad$ het percentage werkenden dat een functie uitoefent die aansluit op het niveau van de gevolgde opleiding;

- $\quad$ het percentage werkenden dat een gemiddeld of een relatief hoog inkomen verdient.

In figuur 4.1 wordt op basis van een pentagram voor de richting elektrotechniek op de vier onderscheiden opleidingsniveaus een voorbeeld gegeven van de mogelijkheid om de vijf bovengenoemde indicatoren gecombineerd visueel vorm te geven. Naarmate de oppervlakte van het gearceerde vlak groter is, is de arbeidsmarktpositie van de schoolverlaters met de desbetreffende opleidingsachtergrond gunstiger. Op deze wijze kan bijvoorbeeld in één oogopslag worden gezien dat de schoolverlaters elektrotechniek op HBO-niveau een veel sterkere arbeidsmarktpositie hebben dan de elektrotechniek schoolverlaters op KMBO-niveau. Een ander punt dat direct opvalt is de relatief veel grotere conjunctuurgevoeligheid van de werkgelegenheid van de LBO- en KMBO-ers.

Figuur 4.1. Grafische weergave van de arbeidsmarktpositie van schoolverlaters op basis van vijf indicatoren
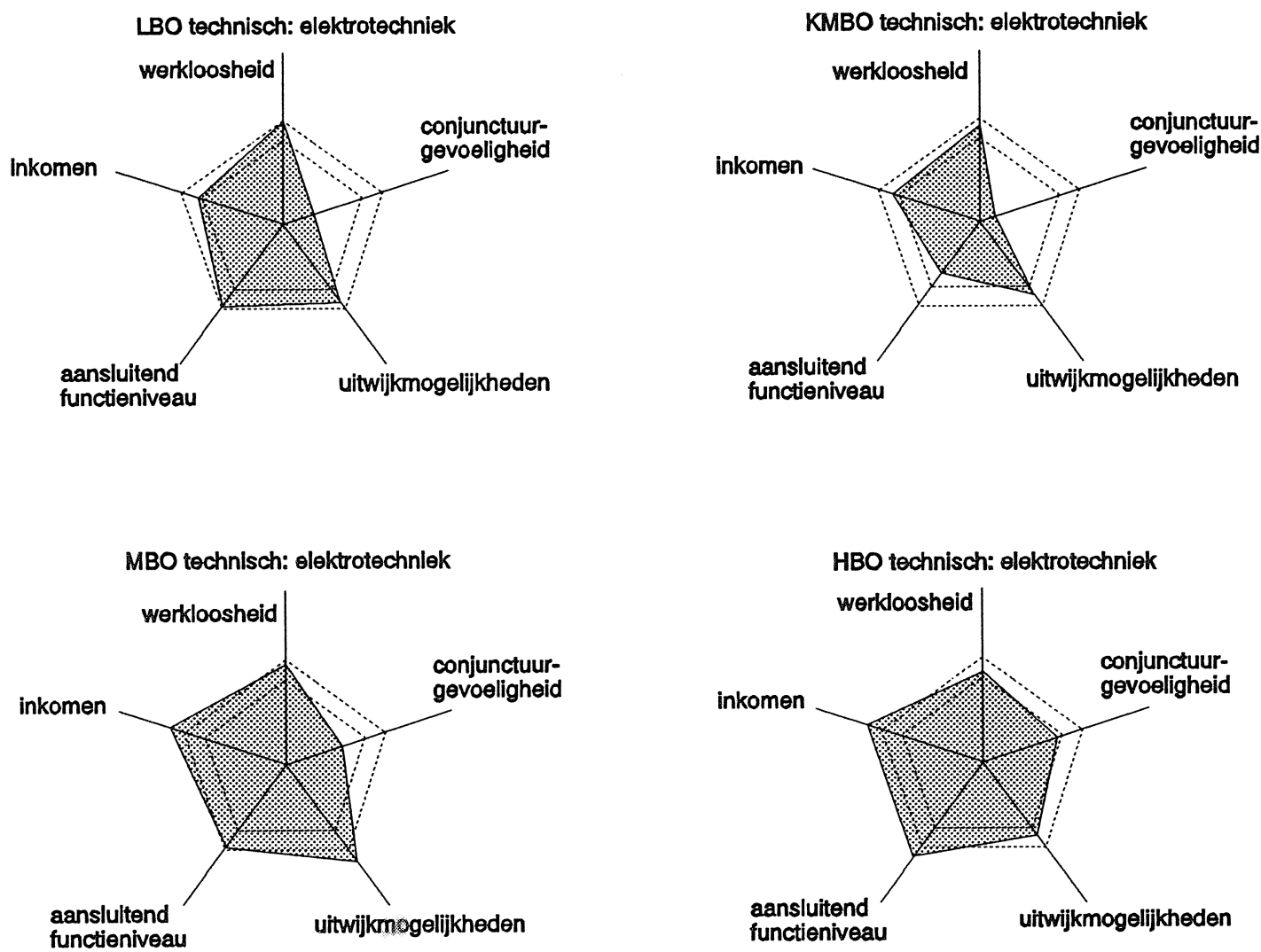

Bron: RUBS 1992/HBO-Monitor 1991/ROA

Om een zo goed mogelijk beeld te kunnen geven van de verschillende aspecten van de actuele arbeidsmarktpositie van schoolverlaters met een bepaalde opleidingsachtergrond, kunnen voor 
de verschillende opleidingsrichtingen heptagrammen worden opgesteld, waarin de volgende zeven indicatoren aan ten grondslag liggen:

- $\quad$ het percentage schoolverlaters dat niet werkloos is;

- $\quad$ het percentage afgestudeerden dat binnen drie maanden een baan heeft gevonden;

- het percentage werkenden dat een functie uitoefent die aansluit op het niveau van de gevolgde opleiding;

- $\quad$ het percentage werkenden dat een functie uitoefent die aansluit bij de richting van de gevolgde opleiding;

- $\quad$ het percentage werkenden dat een full-time functie uitoefent;

- $\quad$ het percentage werkenden dat een vaste aanstelling heeft;

- $\quad$ het percentage werkenden dat een gemiddeld of een relatief hoog inkomen verdient.

In figuur 4.2 wordt op basis van een heptagram respectievelijk voor de richtingen mechanische techniek op LBO-niveau, metaalbewerking op KMBO-niveau en werktuigbouwkunde op MBO- en HBO-niveau, een voorbeeld gegeven van de mogelijkheid om op basis van de zeven bovengenoemde indicatoren de actuele arbeidsmarktpositie visueel vorm te geven.

Figuur 4.2. Grafische weergave van de arbeidsmarktpositie van schoolverlaters op basis van zeven indicatoren
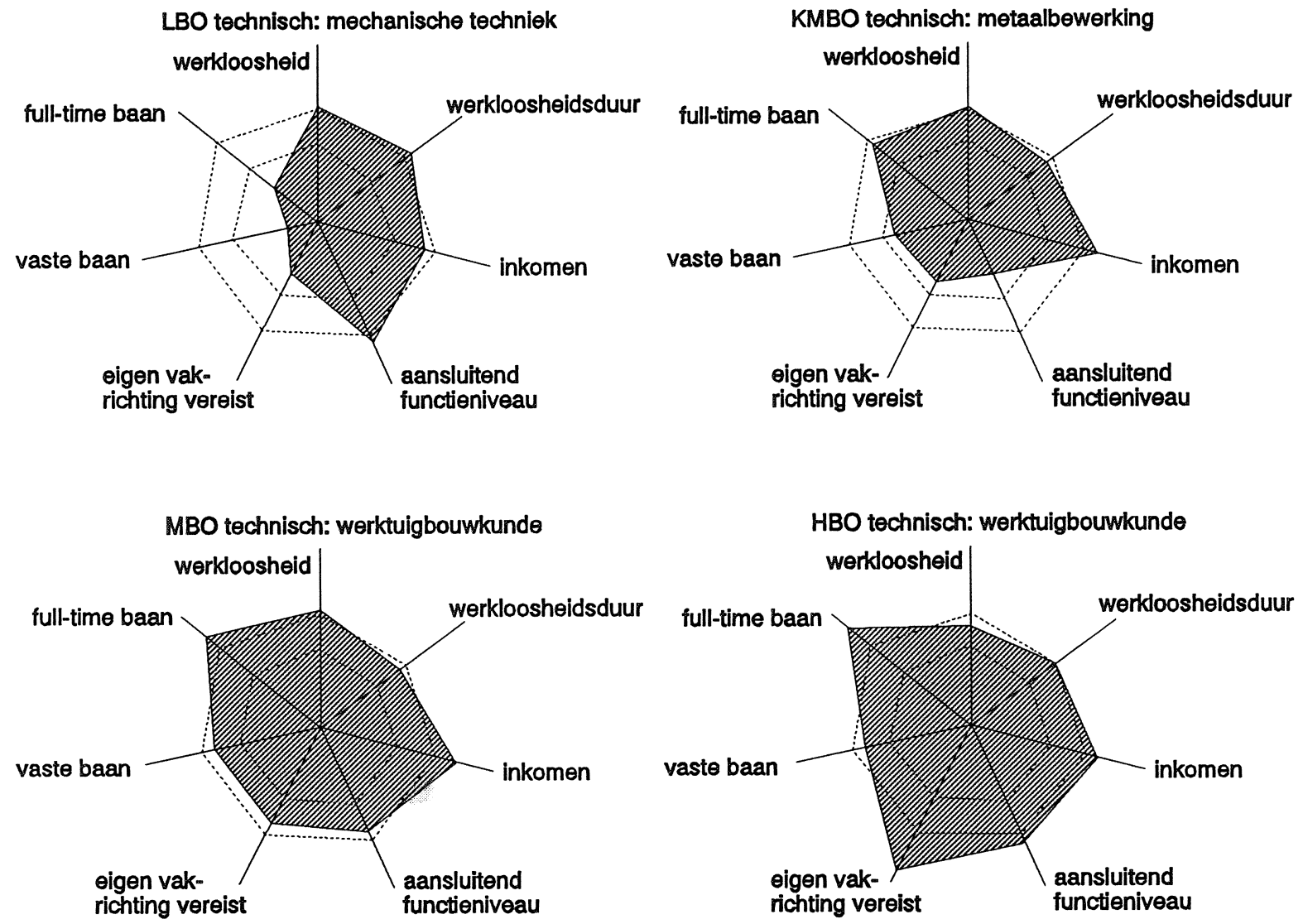

Bron: RUBS 1992/HBO-Monitor 1991/ROA 
Naarmate de oppervlakte van het gearceerde vlak van de heptagrammen groter is, is de actuele arbeidsmarktpositie van de desbetreffende opleidingsrichting gunstiger. Bovendien blijven de afzonderlijke gegevens zichtbaar, zodat de opleidingsrichtingen ook per indicator kunnen worden vergeleken. Ook hier valt direct te zien dat de actuele arbeidsmarktpositie van de MBO- en HBOers over de gehele linie veel beter is dan die van de LBO- en KMBO-ers, waarbij de LBO-ers vooral slecht scoren op de aspecten full-time baan, vaste baan en eigen vakrichting vereist, terwijl de KMBO-ers een slechte positie hebben door het grote aantal tijdelijke dienstverbanden en de gebrekkige aansluiting van de functie die men uitoefent op de richting en het niveau van de gevolgde opleiding.

In zowel figuur 4.1 als figuur 4.2 is telkens met behulp van twee met stippellijnen omlijnde vijfen zevenvlakken is in de figuren een kwalitatieve typering van de onderscheiden indicatoren aangegeven, waarbij een onderscheid wordt gemaakt tussen 'relatief ongunstig', 'gemiddeld' en 'relatief gunstig' (zie ook Wieling, De Grip en Willems, 1990). Bij een ongunstige typering van een bepaalde indicator voor de desbetreffende opleidingsrichting is deze op de bijbehorende as afgebeeld binnen het kleinste vijf- en zevenvlak. Een waarde van de indicator die min of meer gelijk is aan het gemiddelde is weergegeven tussen de twee stippellijnen en een gunstige typering betekent dat de indicatorwaarde op de bijbehorende as buiten het grootste vijf- en zevenvlak ligt. Daarbij zijn de grenzen tussen de typeringen 'relatief ongunstig' en 'gemiddeld' en 'gemiddeld' en 'relatief gunstig' zo getekend dat de afstand tot de oorsprong voor alle indicatoren gelijk is.

Om inzicht te krijgen in de risico's die de schoolverlaters op de arbeidsmarkt ondervinden, is in figuur 4.3 de indicator voor de conjunctuurgevoeligheid van de werkgelegenheid gecombineerd met de indicator voor de beroepsgroepenspreiding van de schoolverlaters. Aan beide indicatoren is een kwalitatieve typering gegeven ${ }^{23}$, die het mogelijk maakt de verschillende opleidingsrichtingen op inzichtelijke wijze ten opzichte van het algeheel beeld te positioneren met betrekking tot de arbeidsmarktrisico's die het volgen van een bepaalde opleiding met zich meebrengt. Dit resulteert in een onderverdeling van figuur 4.3 in negen vlakken. De figuur laat zien dat de technische opleidingen te maken hebben met een relatief hoge mate van conjunctuurgevoeligheid ten opzichte van opleidingen uit andere sectoren.

Bij een hoge beroepsgroepenspreiding en een lage conjunctuurgevoeligheid van de werkgelegenheid nemen de gediplomeerden zonder meer een gunstige positie in ten aanzien van de risico's die zij op de arbeidsmarkt ondervinden (vlak 1). In dit geval is de werkgelegenheidssituatie op de langere termijn relatief stabiel. Bovendien is de arbeidsmarktflexibiliteit groot, waardoor er sprake is van veel uitwijkmogelijkheden naar andere beroepen. Bij de vlakken 2 en 4 is sprake van een betrekkelijk gunstige situatie: een laag risico met betrekking tot de ene indicator en een gemiddeld risico met betrekking tot de andere

23. De waarden van de verschillende indicatoren worden ingedeeld in laag, gemiddeld en hoog op basis van het gemiddelde en de standaarddeviatie van de desbetreffende indicator over alle opleidingsrichtingen (zie Wieling, De Grip en Willems, 1990). De grenzen die in figuur 4.3 zijn gehanteerd zijn gebaseerd op de RUBS-gegevens van 1992 (zie Wieling, Van de Loo en Van der Velden, 1993a). 
indicator. Bij een hoge conjunctuurgevoeligheid van de werkgelegenheid en een lage spreidingscoëfficiënt is er daarentegen sprake van veel risico's op de arbeidsmarkt voor de gediplomeerde schoolverlaters (vlak 9). In deze situatie is er niet alleen sprake van een onzekere werkgelegenheidssituatie op langere termijn, maar bestaan er bovendien weinig uitwijkmogelijkheden. Ook bij de opleidingsrichtingen die zich in vlak 6 of vlak 8 bevinden is er sprake van een relatief ongunstige situatie (een hoog risico bij de ene indicator en een gemiddeld risico bij de andere).

Figuur 4.3. De risico's op de arbeidsmarkt op basis van de conjunctuurgevoeligheid en de beroepsgroepenspreiding (voor beroepen op aansluitend niveau)

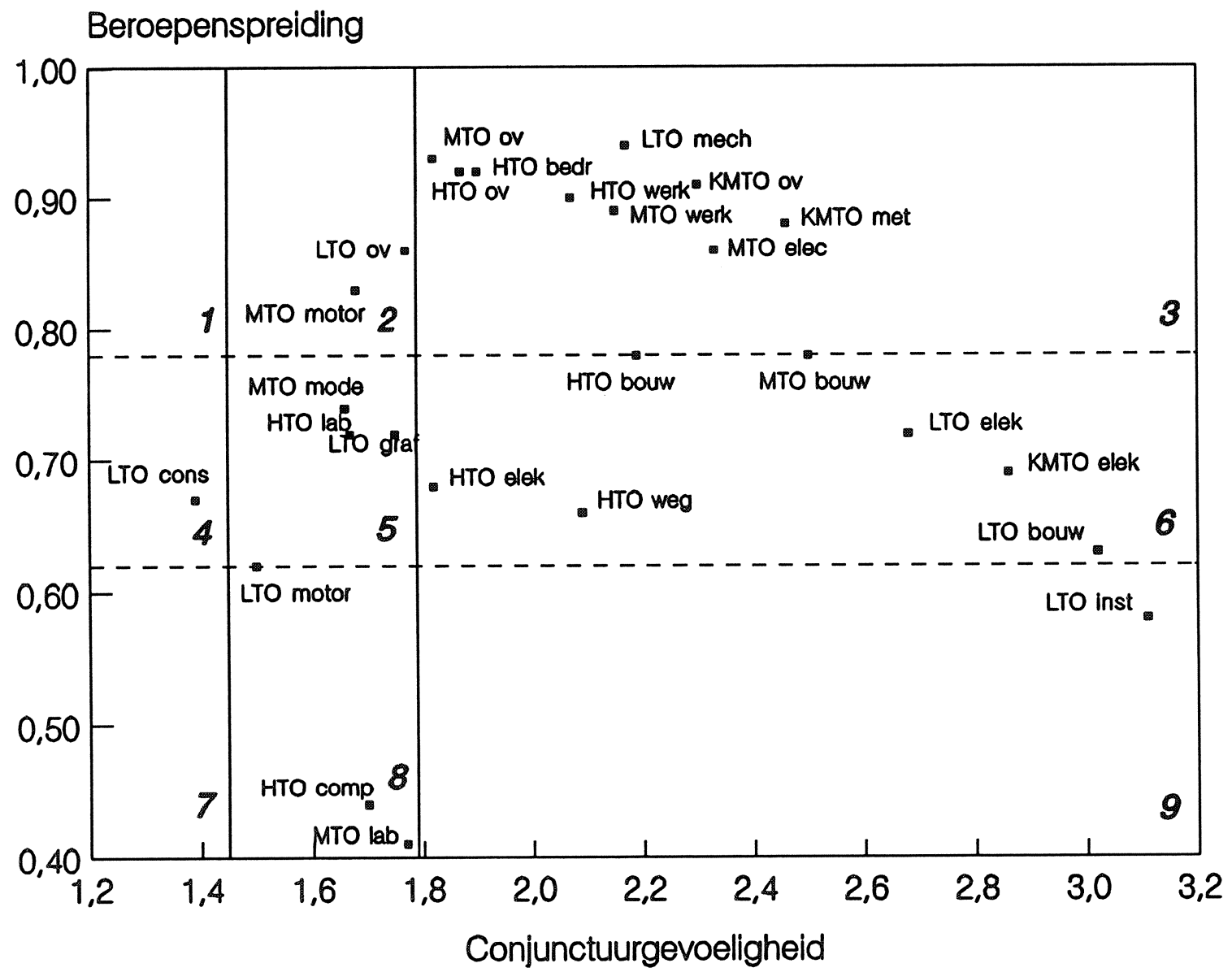

Bron: RUBS 1992/HBO-Monitor 1991/ROA

Met betrekking tot de overige vlakken in de figuur kan geen eenduidige uitspraak worden gedaan omtrent de risico's die de gediplomeerden op de arbeidsmarkt ondervinden. Voor vlak 3 geldt dat er weliswaar sprake is van een instabiele werkgelegenheidssituatie, maar daarentegen zijn de uitwijkmogelijkheden naar andere beroepen groot. Aangenomen mag worden dat indien de werkgelegenheidssituatie voor deze opleidingsclusters op een bepaald moment ongunstig is, dit in zekere mate kan worden opgevangen doordat men kan uitwijken naar andere beroepen. Bij vlak 7 is daarentegen weliswaar sprake van een stabiele werkgelegenheidssituatie maar daar 
staat tegenover dat de beroepenspreiding klein is. Doordat de Gini-Hirschman coëfficiënt de gerealiseerde en niet de potentiële spreiding weergeeft is het hier overigens onduidelijk in hoeverre een verslechtering van de werkgelegenheidssituatie zou kunnen worden opgevangen indien het daadwerkelijk nodig zou zijn uit te wijken naar andere beroepen.

\subsection{Mismatch in de directe aansluiting tussen onderwijs en arbeidsmarkt}

In deze paragraaf worden indicatoren gepresenteerd die op basis van verschillende aspecten van de aansluitingsproblematiek een afgewogen beeld geven van de (eventuele) intredeproblematiek van schoolverlaters op de arbeidsmarkt. Deze zogenaamde 'mismatch'-indicator combineert de zeven indicatoren met betrekking tot de actuele arbeidsmarktpositie van schoolverlaters die reeds in de heptagrammen zijn samengebracht. Op deze wijze kan de kans op werk en de verschillende aspecten van de kwaliteit van werk gecombineerd in beeld worden gebracht.

Om de samenhang tussen deze indicatoren te onderzoeken en na te gaan of deze zinvol zijn te reduceren tot een beperkt aantal dimensies, is de structuur van de correlatiematrix nader geanalyseerd met behulp van factoranalyse. Om tot een zo zuinig mogelijke oplossing te komen, is gekozen voor principale componenten analyse met varimax rotatie en Kaiser-normalisatie. In tabel 4.1 staan de uitkomsten van deze factoranalyse.

Tabel 4.1. Uitkomsten van de factoranalyse.

\begin{tabular}{lrr}
\hline Variabele & factor 1 & factor 2 \\
\hline Geen aansluiting naar richting & 0,80 & 0,01 \\
Tijdelijk werk & 0,77 & 0,13 \\
Deeltijd werk & 0,76 & 0,06 \\
Onderbenutting & 0,73 & 0,36 \\
Relatief laag inkomen & 0,62 & 0,29 \\
Zoekduur langer dan 3 maanden & $-0,03$ & 0,88 \\
Werkloosheid & 0,17 & 0,85 \\
\hline & & 1,52 \\
Eigenwaarde & 2,99 & $21,8 \%$ \\
Verklaarde variantie & $42,7 \%$ & \\
\hline
\end{tabular}

Bron: RUBS 1992/HBO-Monitor 1991/ROA

In de analyse blijken twee factoren te worden geëxtraheerd. De eerste factor kent hoge ladingen van de indicatoren: onderbenutting, geen aansluiting naar richting, een relatief laag inkomen, tijdelijk werk en deeltijdwerk. De tweede factor kent hoge ladingen van de indicatoren werkloosheidspercentage en zoekduur en daarnaast een lage lading van de indicator onderbenutting. Gezamenlijk verklaren de twee gevonden factoren $65 \%$ van de totale variantie. De gemeenschappelijke variantie van de verschillende indicatoren met de beide geëxtraheerde factoren ligt tussen de $45 \%$ en $75 \%$. De zeven indicatoren blijken derhalve gereduceerd te kunnen worden tot twee verschillende dimensies van de arbeidsmarktpositie. De ene dimensie heeft betrekking op de kans op werk. De andere verwijst naar de kwaliteit van het gevonden werk. 
Tabel 4.2. Indicator mismatch in de directe aansluiting tussen onderwijs en arbeidsmarkt

\begin{tabular}{|c|c|c|c|}
\hline \multicolumn{2}{|c|}{ Opleidingsrichting } & \multirow{2}{*}{$\begin{array}{c}\text { kans op werk } \\
\text { indicator } \\
-1,52 \\
-1,64 \\
-0,93 \\
-1,48 \\
-1,30 \\
-1,77 \\
0,30 \\
0,09\end{array}$} & \multirow{2}{*}{$\begin{array}{c}\begin{array}{c}\text { kwaliteit van werk } \\
\text { indicator }\end{array} \\
0,98 \\
1,17 \\
1,33 \\
1,28 \\
1,03 \\
0,89 \\
0,22 \\
1,43\end{array}$} \\
\hline $\begin{array}{l}\text { LBO } \\
\text { LBO } \\
\text { LBO } \\
\text { LBO } \\
\text { LBO } \\
\text { LBO } \\
\text { LBO } \\
\text { LBO }\end{array}$ & $\begin{array}{l}\text { technisch: bouwtechniek } \\
\text { technisch: mechanische techniek } \\
\text { technisch: elektrotechniek } \\
\text { technisch: motorvoertuigentechniek } \\
\text { technisch: consumptieve techniek } \\
\text { technisch: installatietechniek } \\
\text { technisch: grafische techniek } \\
\text { technisch: overig }\end{array}$ & & \\
\hline $\begin{array}{l}\text { KMBO } \\
\text { KMBO } \\
\text { KMBO }\end{array}$ & $\begin{array}{l}\text { technisch: elektrotechniek } \\
\text { technisch: metaalbewerking } \\
\text { technisch: overig }\end{array}$ & $\begin{array}{r}0,11 \\
-0,44 \\
-0,50\end{array}$ & $\begin{array}{l}1,06 \\
0,46 \\
0,74\end{array}$ \\
\hline $\begin{array}{l}\text { MBO } \\
\text { MBO } \\
\text { MBO } \\
\text { MBO } \\
\text { MBO } \\
\text { MBO } \\
\text { MBO }\end{array}$ & $\begin{array}{l}\text { technisch laboratorium } \\
\text { technisch: bouwkunde } \\
\text { technisch: elektrotechniek } \\
\text { technisch: werktuigbouwkunde } \\
\text { technisch: motorvoertuigentechniek } \\
\text { technisch: mode en kleding } \\
\text { technisch: overig }\end{array}$ & $\begin{array}{r}0,00 \\
-0,97 \\
-0,23 \\
-0,47 \\
-0,84 \\
0,61 \\
0,26\end{array}$ & $\begin{array}{r}-0,61 \\
-1,05 \\
-0,62 \\
-0,69 \\
-0,71 \\
0,53 \\
-0,96\end{array}$ \\
\hline $\mathrm{HBO}$ & technisch laboratorium & $-0,47$ & $-1,01$ \\
\hline $\begin{array}{l}\text { HBO } \\
\text { HBO } \\
\text { HBO } \\
\text { HBO } \\
\text { HBO } \\
\text { HBO }\end{array}$ & $\begin{array}{l}\text { technisch: elektrotechniek } \\
\text { technisch: werktuigbouwkunde } \\
\text { technisch: weg-en waterbouwkunde } \\
\text { technisch: bouwkunde, bouwtechnische bedrijfskunde } \\
\text { technisch: computertechniek, informatica } \\
\text { technisch: overig }\end{array}$ & $\begin{array}{r}0,67 \\
0,15 \\
-1,16 \\
-0,30 \\
0,36 \\
0,57\end{array}$ & $\begin{array}{l}-1,35 \\
-1,25 \\
-1,09 \\
-1,21 \\
-1,74 \\
-1,26\end{array}$ \\
\hline HBO & technische bedrijfskunde & $-0,13$ & $-1,18$ \\
\hline
\end{tabular}

Bron: RUBS 1992/HBO-Monitor 1991/ROA

Op basis van de uitkomsten van de factoranalyse is het mogelijk de informatie van de zeven indicatoren te reduceren tot twee kengetallen met gemiddelde 0 en standaarddeviatie 1 (zie tabel 4.2). Naarmate de waarde van een van beide samengestelde indicatoren hoger wordt, is de mismatch groter en is derhalve de initiële aansluiting tussen onderwijs en arbeidsmarkt op het desbetreffende vlak slechter.

\subsection{Arbeidsmarktindicatoren op individueel niveau}

In de voorgaande paragrafen zijn steeds indicatoren op het niveau van de opleiding gepresenteerd. In aanvulling op deze indicatoren kunnen ook op individueel niveau arbeidsmarktindicatoren worden opgesteld die zowel voor de individuele studie- en beroepskeuzevoorlichting als voor het onderwijs- en arbeidsvoorzieningsbeleid van belang kunnen zijn. Deze indicatoren geven inzicht in de effecten van de gevolgde opleiding op de arbeidsmarktkansen van individuele schoolverlaters, gegeven bepaalde achtergrondkenmerken. Voorbeelden hiervan zijn (multivariate) analyses over de factoren die van invloed zijn op het wel of niet krijgen van werk, de werkloosheidsduur of het inkomen. Door naast de gevolgde 
opleiding ook andere variabelen in de analyse te betrekken, kan worden vastgesteld wat het netto-effect is van een bepaalde opleiding op bijvoorbeeld de arbeidsmarktkansen van iemand met bepaalde achtergrondkenmerken.

Tabel 4.3. Schatting van de kans op werkloosheid en het uurloon dat de werkende schoolverlaters van het technisch onderwijs op LBO-niveau verdienen (standaardfouten tussen haakjes)

Variabele" $^{11} \quad$ kans op werkloosheid inkomen

Constante

$-0,21^{* * *}$

$(0,05)$

$-4,75^{* *}$

$(0,99)$

Achtergrondkenmerken

Leeftijd

Vrouw

Niet Nederlandse etnische groep

Opleiding buiten de Randstad

\section{Opleidingskenmerken}

LBO technisch: bouwkunde LBO technisch: elektrotechniek

LBO technisch: mechanische techniek

LBO technisch: motorvoertuigentechniek

LBO technisch: consumptieve techniek

LBO technisch: installatietechniek

LBO technisch: grafische techniek

LBO technisch: overig

$0,01 * *$

$0,03^{* \cdots *}$

$0,04^{* * *}$

$0,02^{* * *}$

$(0,00)$
$(0,01)$
$(0,01)$
$(0,01)$

$0,58^{* *}$

$-0,34$

$(0,06)$

$-0,09$

$(0,18)$

$(0,27)$

$(0,09)$

$\begin{array}{rlll}-0,01 & (0,01) & 0,85^{* * *} & (0,16) \\ \text { ref. } & & \text { ref. } & \\ -0,01 & (0,01) & 0,28^{*} & (0,17) \\ -0,01 & (0,01) & 0,09 & (0,17) \\ -0,02^{*} & (0,01) & 0,83^{* * *} & (0,17) \\ - & & 0,14 & (0,26) \\ -0,01 & (0,01) & 1,00^{* * *} & (0,34) \\ -0,00 & (0,01) & 0,25 & (0,23)\end{array}$

Vooropleiding:

MAVO- of LBO-vooropleiding

$-0,01^{*} \quad(0,01) \quad 0,32^{* * *} \quad(0,12)$

- $\quad=$ geen van de schoolverlaters van de richting LBO technisch installatietechniek is werkloos

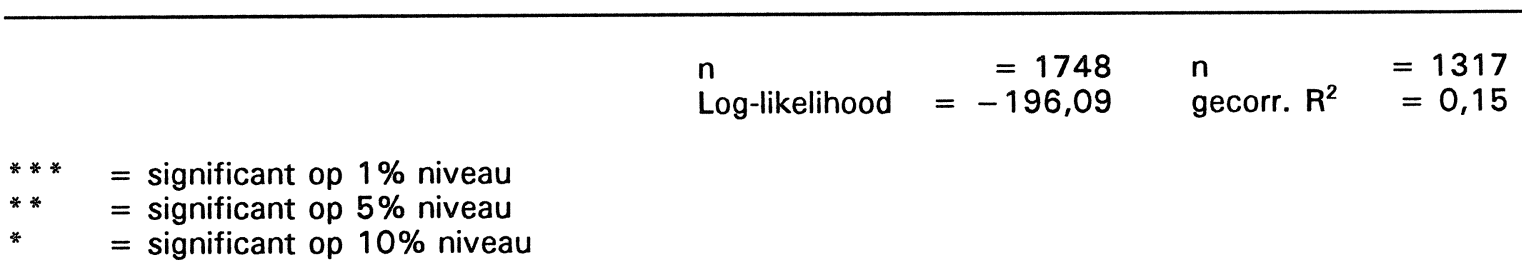

1) Leeftijd is als interval-variabele opgenomen. De overige variabelen betreffen dummy-variabelen.

Bron: RUBS 1992/ROA

Ter illustratie van de mogelijkheden die dergelijke analyses bieden staan in de tabellen 4.3 tot en met 4.5 voor respectievelijk het technisch onderwijs op LBO-, MBO- (inclusief KMBO) en HBOniveau, de resultaten van de multivariate analyses met betrekking tot de kans op werkloosheid en het inkomen. Vanwege de verschillen in de afhankelijke variabele tussen de enquêtes, is ervoor gekozen de regressievergelijkingen per opleidingsniveau te schatten ${ }^{24}$.

24. Bij de werkloosheid moet rekening worden gehouden met het verschil in peilmoment tussen beide enquêtes. Ten aanzien van het inkomen geldt dat het bij de schoolverlaters van de RUBS-enquête gaat om het netto uurloon, terwijl van de HBO-afgestudeerden het bruto uurloon bekend is. 
Tabel 4.4. Schatting van de kans op werkloosheid en het uurloon dat de werkende schoolverlaters van het technisch onderwijs op KMBO- en MBO-niveau verdienen (standaardfouten tussen haakjes)

\begin{tabular}{|c|c|c|c|c|}
\hline \multirow{2}{*}{$\begin{array}{l}\text { Variabele" }^{\prime \prime} \\
\text { Constante }\end{array}$} & \multicolumn{2}{|c|}{ kans op werkloosheid } & \multicolumn{2}{|c|}{ inkomen } \\
\hline & $-0,32^{* * *}$ & $(0,04)$ & $-0,92$ & $(0,84)$ \\
\hline \multicolumn{5}{|l|}{ Achtergrondkenmerken } \\
\hline $\begin{array}{l}\text { Leeftijd } \\
\text { Vrouw } \\
\text { Niet Nederlandse etnische groep } \\
\text { Opleiding buiten de Randstad }\end{array}$ & $\begin{array}{l}0,01^{\ldots \ldots} \\
0,00 \\
0,04^{\ldots \ldots} \\
0,01\end{array}$ & $\begin{array}{l}(0,00) \\
(0,01) \\
(0,01) \\
(0,01)\end{array}$ & $\begin{array}{l}0,50 * \ldots \\
-0,40 * \\
-0,31 \\
-0,09\end{array}$ & $\begin{array}{l}(0,04) \\
(0,17) \\
(0,30) \\
(0,11)\end{array}$ \\
\hline \multicolumn{5}{|l|}{ Opleidingskenmerken } \\
\hline $\begin{array}{l}\text { KMBO technisch: elektrotechniek } \\
\text { KMBO technisch: metaalbewerking } \\
\text { KMBO technisch: overig } \\
\text { MBO technisch laboratorium } \\
\text { MBO technisch: bouwkunde } \\
\text { MBO technisch: elektrotechniek } \\
\text { MBO technisch: werktuigbouwkunde } \\
\text { MBO technisch: motorvoertuigentechniek } \\
\text { MBO technisch: mode en kleding } \\
\text { MBO technisch: overig }\end{array}$ & $\begin{array}{r}0,04 \\
-0,04 \\
0,01 \\
0,00 \\
-0,02 \\
\text { ref. } \\
-0,01 \\
-0,04 \\
0,02 \\
-0,00\end{array}$ & $\begin{array}{l}(0,01) \\
(0,03) \\
(0,01) \\
(0,01) \\
(0,01) \\
(0,01) \\
(0,03) \\
(0,01) \\
(0,01)\end{array}$ & $\begin{array}{l}-1,64^{* * *} \\
-0,71^{*} \\
-0,35 \\
0,70^{* * *} \\
0,17 \\
\text { ref. } \\
0,22 \\
-0,05 \\
-1,18^{\ldots *} \\
0,08\end{array}$ & $\begin{array}{l}(0,34) \\
(0,38) \\
(0,25) \\
(0,24) \\
(0,21) \\
(0,17) \\
(0,42) \\
(0,23) \\
(0,18)\end{array}$ \\
\hline \multicolumn{5}{|l|}{ Vooropleiding: } \\
\hline $\begin{array}{l}\text { LBO } \\
\text { KMBO } \\
\text { MBO } \\
\text { MAVO } \\
\text { HAVO } \\
\text { VWO } \\
\text { Overig } \\
\text { Geen diploma vooropleiding }\end{array}$ & $\begin{array}{r}0,00 \\
0,02 \\
-0,01 \\
\text { ref. } \\
-0,00 \\
0,03 \\
- \\
0,03\end{array}$ & $\begin{array}{l}(0,01) \\
(0,03) \\
(0,02) \\
(0,01) \\
(0,02) \\
(0,01)\end{array}$ & $\begin{array}{r}-0,09 \\
-2,04 \\
0,21 \\
r e f \\
0,05 \\
-0,32 \\
-0,01 \\
-0,19\end{array}$ & $\begin{array}{l}(0,12) \\
(0,64) \\
(0,28) \\
(0,17) \\
(0,54) \\
(1,04) \\
(0,30)\end{array}$ \\
\hline
\end{tabular}

= geen van de schoolverlaters met een vooropleiding behorend tot de categorie "overig" is werkloos

\begin{tabular}{|c|c|c|c|c|}
\hline & $\begin{array}{l}n \\
\text { Log-likelihood }\end{array}$ & $\begin{array}{r}=3837 \\
=-578,59\end{array}$ & $\begin{array}{l}n \\
\text { gecorr. } R^{2}\end{array}$ & $\begin{array}{l}=2116 \\
=0,25\end{array}$ \\
\hline $\begin{array}{l}=\text { significant op } 1 \% \text { niveau } \\
=\text { significant op } 5 \% \text { niveau }\end{array}$ & & & & \\
\hline
\end{tabular}

1) Leeftijd is als interval-variabele opgenomen. De overige variabelen betreffen dummy-variabelen.

Bron: RUBS 1992/ROA

Bij het bepalen van de kans op werkloosheid zijn de schoolverlaters die zich niet daadwerkelijk aanbieden op de arbeidsmarkt, zoals gebruikelijk, buiten beschouwing gelaten. De kans op werkloosheid is geschat op basis van een probit-vergelijking. De uit deze schatting resulterende parameters zijn niet direct interpreteerbaar. Derhalve zijn de parameterwaarden omgerekend, zodat ze bij benadering de verandering in de kans weergeven bij een verandering in de onafhankelijke variabele met 1 eenheid, waarbij de gemiddelde waarden van de onafhankelijke variabelen het uitgangspunt vormen. Bij de regressievergelijkingen die betrekking hebben op het 
uurloon is, in plaats van de logaritme van het uurloon te nemen, het werkelijke uurloon als afhankelijke gekozen. Hierdoor geven de parameterwaarden rechtstreeks de toename van het uurloon aan bij een verandering in de waarde van de exogenen.

Tabel 4.5. Schatting van de kans op werkloosheid en het uurloon dat de werkende schoolverlaters van het technisch onderwijs op HBO-niveau verdienen (standaardfouten tussen haakjes)

\begin{tabular}{|c|c|c|c|c|}
\hline \multirow{2}{*}{$\begin{array}{l}\text { Variabele" }^{11} \\
\text { Constante }\end{array}$} & \multicolumn{2}{|c|}{ kans op werkloosheid } & \multicolumn{2}{|c|}{ inkomen } \\
\hline & $-0,12$ & $(0,08)$ & $7,57^{* * *}$ & $(1,20)$ \\
\hline \multicolumn{5}{|l|}{ Achtergrondkenmerken } \\
\hline $\begin{array}{l}\text { Leeftijd } \\
\text { Vrouw } \\
\text { Opleiding buiten de Randstad }\end{array}$ & $\begin{array}{r}-0,00 \\
-0,08^{* *} \\
0,03^{* *}\end{array}$ & $\begin{array}{l}(0,00) \\
(0,03) \\
(0,01)\end{array}$ & $\begin{aligned} & 0,48^{* * *} \\
- & 0,37 \\
- & 0,19\end{aligned}$ & $\begin{array}{l}(0,05) \\
(0,35) \\
(0,21)\end{array}$ \\
\hline \multicolumn{5}{|l|}{ Opleidingskenmerken } \\
\hline $\begin{array}{l}\text { HBO technisch laboratorium } \\
\text { HBO techn.: elektrotechniek } \\
\text { HBO techn.: werktuigbouwkunde } \\
\text { HBO techn.: weg- en waterbouwkunde } \\
\text { HBO techn.: bouwkunde, bouwtechn. bedrijfskunde } \\
\text { HBO techn.: computertechniek, informatica } \\
\text { HBO techn.: overig } \\
\text { HBO technische bedrijfskunde }\end{array}$ & $\begin{array}{r}-0,02 \\
r e f \\
-0,00 \\
-0,07^{*} \\
-0,04 \\
-0,00 \\
-0,03\end{array}$ & $\begin{array}{l}(0,03) \\
(0,02) \\
(0,03) \\
(0,03) \\
(0,02) \\
(0,03)\end{array}$ & $\begin{array}{r}-0,77^{*} \\
\text { ref. } \\
-0,21 \\
-0,34 \\
-0,16 \\
0,51 \\
0,68^{*} \\
1,06\end{array}$ & $\begin{array}{l}(0,39) \\
(0,30) \\
(0,42) \\
(0,42) \\
(0,53) \\
(0,35) \\
(0,38)\end{array}$ \\
\hline $\begin{array}{l}\text { Vooropleiding: } \\
\text { HAVO } \\
\text { VWO } \\
\text { MBO } \\
\text { HBO } \\
\text { Overig }\end{array}$ & $\begin{array}{r}\text { ref. } \\
-0,00 \\
-0,03 \\
-0,01 \\
0,05\end{array}$ & $\begin{array}{l}(0,02) \\
(0,02) \\
(0,04) \\
(0,05)\end{array}$ & $\begin{array}{r}r e f . \\
0,07 \\
-0,37 \\
0,23 \\
-1,41^{*}\end{array}$ & $\begin{array}{l}(0,26) \\
(0,26) \\
(0,55) \\
(0,81)\end{array}$ \\
\hline
\end{tabular}

= geen van de schoolverlaters van de richting HBO technisch weg- en waterbouwkunde is werkloos

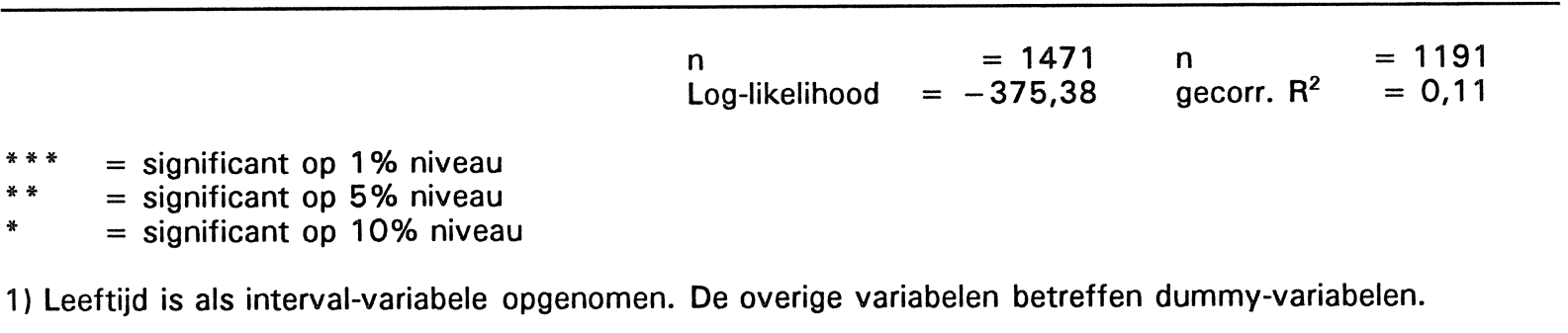

Bron: HBO-Monitor 1991/ROA

De eerste groep verklarende variabelen bestaat uit een aantal achtergrondkenmerken: leeftijd, geslacht, etniciteit en de regio waar men de opleiding heeft gevolgd (al dan niet buiten de Randstad). De tweede groep exogenen heeft betrekking op de verschillende opleidingsrichtingen. Daarnaast zijn ook enkele variabelen in de analyse opgenomen met betrekking tot de vooropleiding. Deze variabelen kunnen de effecten van de gevolgde leerroutes in beeld brengen, hetgeen een indicatie geeft van de effectiviteit van de verschillende leerroutes. Overigens moet daarbij worden opgemerkt, dat bij de schatting van het uurloon voor technisch opgeleiden van het LBO slechts kan worden nagegaan of de schoolverlaters reeds eerder een diploma van het 
LBO of MAVO hebben behaald.

Naast deze groepen onafhankelijke variabelen zouden eventueel ook de baankenmerken in de regressievergelijkingen kunnen worden opgenomen. Zo kan in de inkomensvergelijking rekening worden gehouden met het feit of men al dan niet een tijdelijke baan heeft of een functie uitoefent die onder het niveau van de gevolgde opleiding ligt. Bovendien kan de vereiste vakrichting worden opgenomen en de bedrijfssector waarin de schoolverlaters werkzaam zijn en de plaats van het bedrijf waarin men werkt. Deze variabelen kunnen van belang zijn voor het scholings- en arbeidsmarktbeleid. Aangezien leerlingen op het moment waarop ze voor een opleiding kiezen doorgaans nog niet weten waar men in de toekomst werkzaam zal zijn, zijn de variabelen die betrekking hebben op de werkkring echter minder relevant voor de studie- en beroepskeuzevoorlichting. In de hier gepresenteerde regressievergelijkingen is deze groep onafhankelijke variabelen derhalve niet meegenomen.

Ter illustratie wordt voor een tweetal vergelijkingen aangegeven welke factoren significante invloed hebben op de kans op werkloosheid en het inkomen. Met betrekking tot de kans op werkloosheid blijkt uit tabel $\mathbf{4 . 3}$ dat oudere LBO-schoolverlaters een grotere kans hebben om ongeveer één jaar na het verlaten van de LBO-opleiding werkloos te zijn. Ook voor vrouwen, allochtonen en schoolverlaters die hun LBO-opleiding buiten de Randstad hebben gevolgd, is de kans werkloos te zijn groter. Daarentegen zijn gediplomeerden van de richting consumptieve techniek minder snel werkloos dan schoolverlaters die de richting elektrotechniek hebben afgerond. Ook zijn schoolverlaters die al eerder een MAVO- of LBO-diploma hebben gehaald minder vaak werkloos. Tabel $\mathbf{4 . 4}$ laat zien dat oudere MBO-schoolverlaters een hoger inkomen verdienen, terwijl vrouwen daarentegen juist een lager inkomen hebben. Ten opzicht van de gediplomeerden van de richting elektrotechniek van het $\mathrm{MBO}$, verdienen de gediplomeerden van de KMBO-opleidingen elektrotechniek en metaalbewerking en van de richting mode en kleding van het MBO een lager salaris. Gediplomeerden van het MBO technisch laboratorium verdienen juist een hoger uurloon. Indien schoolverlaters voor hun MBO-opleiding een opleiding in het KMBO hebben gevolgd verdient men een lager inkomen dan de gediplomeerden met een MAVOvooropleiding.

Op basis van de schattingsresultaten kan een meer op het individu gericht beeld van de arbeidsmarktsituatie worden gegeven. Hiervan worden de volgende twee voorbeelden gepresenteerd:

Werkloosheid:

De referentie persoon is een 25 jaar oude man die een elektrotechnische opleiding in het hoger beroepsonderwijs in de Randstad heeft gevolgd en een HAVO-vooropleiding heeft afgerond. De kans dat deze persoon werkloos zal zijn ongeveer één jaar na het verlaten van de opleiding in het hoger technisch onderwijs bedraagt 8,3\%. Voor een mannelijke afgestudeerde van de richting werktuigbouwkunde met een VWO-vooropleiding is de kans op werkloosheid ongeveer eén jaar na de hogere technische opleiding enigszins kleiner, namelijk 7,6\% (zie tabel 4.4).

Inkomen:

Een 22 jaar oude Nederlandse man die een elektrotechnische opleiding in het middelbaar beroepsonderwijs in de Randstad heeft gevolgd en een MAVO-vooropleiding heeft afgerond, 
verdient $1-0,92+22 * 0,50=1$ 10,08 gulden per uur. Daarentegen verdient een 22-jarige Nederlandse vrouw die een opleiding mode en kleding in het MBO heeft afgerond slechts $1-0,92$ $+22 * 0,50-0,40 * 1-1,18 * 1=18,50$ gulden per uur (zie tabel 4.3).

Tot slot van dit hoofdstuk moet worden opgemerkt dat het schatten van een loonvergelijking per opleidingsniveau een ander aandachtspunt naar voren brengt, namelijk op welke wijze de indicatoren moeten worden getypeerd. Zoals in hoofdstuk 2 al is opgemerkt is het wellicht ten aanzien van een aantal indicatoren wenselijk een typering per opleidingsniveau op te stellen naast of zelfs in plaats van een typering op basis van de waarde van een indicator voor een bepaald opleidingstype ten opzichte van de waarden van de desbetreffende indicator van alle andere opleidingstypen. In het informatiesysteem onderwijs-arbeidsmarkt wordt ook voor enkele kengetallen aan een tweeledige typering gedacht, waarbij enerzijds de relatieve positie van een bepaalde opleidingstype wordt uitgedrukt ten opzichte van alle andere opleidingstypen en anderzijds de positie wordt aangegeven ten opzichte van de andere opleidingstypen op hetzelfde opleidingsniveau. 


\section{VOORTIJDIGE SCHOOLVERLATERS}

\subsection{Inleiding}

Dit hoofdstuk gaat in op het berekenen van indicatoren op basis van gegevens van schoolverlaters die voortijdig hun opleiding hebben verlaten. Ondanks het feit dat de kans op uitvallen en de gevolgen daarvan zeer relevant zijn, is deze informatie wellicht minder belangrijk voor de studie- en beroepskeuzevoorlichting, maar juist van groter belang voor beleidsdoeleinden. Informatie over de arbeidsmarktpositie van schoolverlaters die voortijdig hun opleiding hebben afgerond kan een beter inzicht geven in de problematiek waarmee deze schoolverlaters na het beëindigen van hun opleiding te maken krijgen.

In het huidige informatiesysteem onderwijs-arbeidsmarkt wordt de instroom van voortijdige schoolverlaters op de arbeidsmarkt teruggerekend naar de hoogste voltooide opleiding. Ook in de EBB wordt geen informatie over voortijdige schoolverlaters gegeven ${ }^{25}$. Met de gegevens van de RUBS-enquête over voortijdige schoolverlaters kan echter worden nagegaan in hoeverre dit terecht is. Er kan inzicht worden verkregen in de verschillen in arbeidsmarktpositie tussen schoolverlaters die wel en schoolverlaters die niet hun opleiding hebben afgemaakt. Bovendien kan worden nagegaan of er verschillen bestaan tussen schoolverlaters die een bepaalde opleiding voortijdig hebben afgebroken en schoolverlaters die op een lager niveau een opleiding hebben voltooid. Zo kan bijvoorbeeld worden onderzocht of de arbeidsmarktpositie van voortijdige schoolverlaters van het $M B O$ enerzijds veel afwijkt van de arbeidsmarktpositie van gediplomeerden van het MBO of anderzijds van de positie van gediplomeerden van het LBO. Het is wellicht mogelijk in het informatiesysteem ten behoeve van bepaalde beleidsdoeleinden aparte aandacht aan de voortijdige schoolverlaters te besteden.

Voordat de indicatoren worden besproken is het van belang aan te geven wanneer iemand tot de voortijdige schoolverlaters, ook wel eens drop-outs genoemd, behoort. In de Schoolverlatersbrieven uit 1988 en 1991 (zie Ministerie van Sociale Zaken en Werkgelegenheid, 1988 en Centraal Bestuur voor de Arbeidsvoorziening, 1991) wordt iemand als drop-out gedefinieerd als men een AVO- of LBO-studie heeft afgebroken en geen enkele vorm van dagonderwijs heeft afgerond.

Het zijn echter niet alleen deze drop-outs die vaak een kwetsbare situatie terechtkomen. De leerlingen met een LBO-diploma komen weliswaar vaak aan werk, maar zonder verdere verwerving van een beroepskwalificatie is hun positie op de arbeidsmarkt eveneens instabiel. Derhalve wordt momenteel door het Ministerie van Onderwijs en Wetenschappen de nadruk gelegd op een minimale beroepskwalificatie voor alle jongeren (zie Tweede Kamer der Staten Generaal, 1993). Dit houdt in dat de algemeen aanvaarde minimum startkwalificatie, die door zoveel mogelijk leerlingen moet worden bereikt, een beroepsopleiding op ten minste het niveau

25. Deze schoolverlaters worden gecodeerd naar het hoogste behaalde diploma. 
van beginnend beroepsbeoefenaar is, hetgeen overeenkomt met het niveau primair leerlingwezen of kort middelbaar beroepsonderwijs. In deze visie wordt iemand als voortijdig schoolverlater gezien, indien men niet een dergelijke startkwalificatie heeft behaald. Volgens deze omschrijving behoren de leerlingen die in het bezit zijn van een LBO- of MAVO-diploma en het onderwijs verlaten of wel doorstromen naar de tweede fase van het voortgezet onderwijs, maar hier niet de omschreven minimum startkwalificatie behalen, eveneens tot de voortijdige schoolverlaters. Naast het LBO en MAVO is ook het HAVO en VWO niet bedoeld als eindonderwijs; deze groep blijft vooralsnog buiten beschouwing bij het definiëren van de groep voortijdige schoolverlaters.

In dit rapport worden tot de voortijdige schoolverlaters degenen gerekend die in het voorafgaande studiejaar de opleiding zonder diploma hebben verlaten. Het betreft hier niet alleen de voortijdige schoolverlaters die in het examenjaar van de opleiding hebben afgebroken, maar ook degenen die reeds voor het examenjaar met de opleiding zijn gestopt ${ }^{26}$. De informatie over de voortijdige schoolverlaters heeft slechts betrekking op de schoolverlaters die in het kader van de RUBS-enquête zijn benaderd, omdat de HBO-Monitor alleen betrekking heeft op afgestudeerden.

Bedacht moet worden dat de respons van de ongediplomeerde schoolverlaters in het RUBSonderzoek van 1992 zeer laag is. Derhalve dienen de uitkomsten met enige voorzichtigheid te worden geïnterpreteerd. Daarnaast is het mogelijk dat de groep voortijdige schoolverlaters een zeer heterogene groep vormt met betrekking tot het leerjaar waarin men voortijdig met de studie is gestopt. Indien de groep grotendeels zou bestaan uit schoolverlaters die hun opleiding reeds in het beginstadium hebben beëindigd zou de opleiding die ze daarvoor wel hebben voltooid eigenlijk beter het uitgangspunt kunnen vormen voor het bepalen van de positie op de arbeidsmarkt. Bij uitval in de eindfase van de opleiding komt de arbeidsmarktpositie van de schoolverlaters wellicht meer overeen met de arbeidsmarktpositie van de gediplomeerde schoolverlaters. Overigens zal een deel van de voortijdige schoolverlaters via het leerlingwezen of het in-service onderwijs alsnog trachten in het bezit te komen van de benodigde kwalificaties. De RUBS-gegevens maken het mogelijk dit in beeld te brengen.

Evenals in hoofdstuk 3 worden de verschillende indicatoren ter illustratie gepresenteerd voor de schoolverlaters van het technisch onderwijs. Daarbij worden de resultaten voor zowel de voortijdige schoolverlaters als voor de gediplomeerde schoolverlaters weergegeven. De indicatoren zullen overigens niet naar richting worden verbijzonderd, maar worden per ROAopleidingstype gepresenteerd ${ }^{27}$. Dit gebeurt niet alleen omdat de aantallen voortijdige schoolverlaters bij een opsplitsing erg klein worden, maar ook omdat het minder zinvol lijkt de bestemming van schoolverlaters te relateren aan een opleiding die zij niet hebben afgemaakt en

26. Alleen de schoolverlaters die in het eerste of tweede jaar van het LBO en in de brugklas van het AVO hun opleiding voortijdig verlaten zijn niet geënquêteerd.

27. Hierbij behoren de opleidingsrichtingen in het $\mathrm{KMBO}$ bij het $\mathrm{MBO}$, conform de indeling naar ROAopleidingstype, die is gebaseerd op de SOI-indeling. 
waarvan de opleidingsdoelstellingen dus niet volledig kunnen zijn gerealiseerd (Van Laarhoven en Waslander, 1990). Vanwege het kleine aantal voortijdige schoolverlaters in het opleidingstype MBO technisch laboratorium zullen voor dit opleidingstype geen gegevens worden gepresenteerd.

\subsection{Indicatoren voor voortijdige schoolverlaters}

In deze paragraaf worden enkele indicatoren gepresenteerd die overeenkomen met de informatie die in hoofdstuk 3 is weergegeven. Derhalve zal hier niet uitvoerig op de gepresenteerde indicatoren worden ingegaan, maar worden alleen opmerkingen gemaakt voor zover het specifieke aandachtspunten met betrekking tot voortijdige schoolverlaters betreft. In principe kan alle informatie die in hoofdstuk 3 is gepresenteerd ook voor de voortijdige schoolverlaters worden opgesteld. De risico-indicatoren zullen echter niet voor de voortijdige schoolverlaters worden berekend.

Tabel 5.1. Werkloosheidspercentage per opleidingstype

\begin{tabular}{ll}
\hline Opleidingstype & $\%$
\end{tabular}

Gediplomeerde schoolverlaters

LBO technisch 3

MBO technisch 4

Voortijdige schoolverlaters

LBO technisch $\quad 6$

MBO technisch $\quad 7$

Bron: RUBS 1992/ROA

In tabel 5.1. worden de werkloosheidspercentages voor zowel gediplomeerde als voortijdige schoolverlaters van de technische opleidingstypen in het LBO en MBO gepresenteerd. Tabel 5.2 geeft een overzicht van de duur van de intredewerkloosheid van de desbetreffende opleidingstypen.

Indien de werkloosheidspercentages en de duur van de intredewerkloosheid geen duidelijk slechtere situatie voor de voortijdige schoolverlaters laten zien ten opzichte van de gediplomeerde schoolverlaters, moet worden beseft dat de schoolverlaters nogal eens hun opleiding afbreken als ze ergens werk hebben gevonden. Wat dat betreft kan het werkloosheidsverschil tussen de gediplomeerde en voortijdige schoolverlaters toenemen naarmate men langer van school af is. De voortijdige schoolverlaters zullen immers op dit punt met name op de langere termijn een kwetsbaardere positie innemen op de arbeidsmarkt dan de gediplomeerde schoolverlaters. Tabel 5.1 laat overigens zien dat de ongediplomeerde schoolverlaters vaker werkloos zijn. Daarnaast zijn met name de voortijdige schoolverlaters van het LBO technisch langer op zoek naar een baan in vergelijking met de gediplomeerde LBO-ers. 
Tabel 5.2. Duur van de intredewerkloosheid per opleidingstype

\begin{tabular}{|c|c|c|c|c|}
\hline Opleidingstype & $\begin{array}{c}\text { niet werkloos } \\
\text { geweest } \\
\%\end{array}$ & $\begin{array}{c}1-3 \\
\text { maanden } \\
\%\end{array}$ & $\begin{array}{c}4-6 \\
\text { maanden } \\
\%\end{array}$ & $\begin{array}{c}>6 \\
\text { maanden } \\
\%\end{array}$ \\
\hline \multicolumn{5}{|c|}{ Gediplomeerde schoolverlaters } \\
\hline $\begin{array}{ll}\text { LBO } & \text { technisch } \\
\text { MBO technisch }\end{array}$ & $\begin{array}{l}86 \\
75\end{array}$ & $\begin{array}{l}10 \\
17\end{array}$ & $\begin{array}{l}2 \\
5\end{array}$ & $\begin{array}{l}2 \\
3\end{array}$ \\
\hline \multicolumn{5}{|c|}{ Voortijdige schoolverlaters } \\
\hline $\begin{array}{ll}\text { LBO } & \text { technisch } \\
\text { MBO } & \text { technisch }\end{array}$ & $\begin{array}{l}80 \\
75\end{array}$ & $\begin{array}{l}12 \\
17\end{array}$ & $\begin{array}{l}5 \\
5\end{array}$ & $\begin{array}{l}3 \\
3\end{array}$ \\
\hline
\end{tabular}

Bron: RUBS 1992/ROA

Tabel 5.3. Belangrijkste beroepsgroepen per opleidingstype

LBO technisch: gediplomeerde schoolverlaters

Timmerman

Auto-, motorrijwiel-, bromfietsmonteur

Kok, keukenassistente

8

Elektricien (aanleg/reparatie)

Winkelbediende, verkoper

6

Loodgieter, verwarmingsmonteur e.d.

LBO technisch: voortijdige schoolverlaters

Winkelbediende, verkoper

Elektricien (aanleg/reparatie)

Timmerman

Kok, keukenassistente

Auto-, motorrijwiel-, bromfietsmonteur

6

Lader, losser, magazijnknecht e.d.

MBO technisch: gediplomeerde schoolverlaters

Winkelbediende, verkoper

Elektricien (aanleg/reparatie)

Bouwkundig, technisch tekenaar e.d.

MBO technisch: voortijdige schoolverlaters

Winkelbediende, verkoper

Elektricien (aanleg/reparatie)

Auto-, motorrijwiel-, bromfietsmonteur

Bron: RUBS 1992/ROA

Door na te gaan in welke beroepen en branches de voortijdige schoolverlaters werkzaam zijn, kan een indruk worden verkregen van de positie op de arbeidsmarkt ten tijde van de enquête. De eerste baan is ook van groot belang voor de doorgroeimogelijkheden van schoolverlaters. 
Informatie over de beroepen en branches waarin de schoolverlaters terechtkomen, geeft derhalve ook een indicatie voor de toekomst van de voortijdige schoolverlaters. In tabel 5.3 worden de belangrijkste beroepsgroepen waarin de voortijdige schoolverlaters terechtkomen aangegeven, terwijl in tabel 5.4 een overzicht geeft van de belangrijkste bedrijfsklassen waarin de voortijdige en gediplomeerde schoolverlaters werkzaam zijn. In het algemeen zijn voortijdig schoolverlaters van het LBO vaker werkzaam in de detailhandel en als winkelbediende of verkoper, terwijl ze juist minder vaak als timmerman of auto-, motorrijwiel- of bromfietsmonteur werkzaam zijn.

Tabel 5.4. Belangrijkste bedrijfsklassen per opleidingstype

LBO technisch: gediplomeerde schoolverlaters

Bouwnijverheid

Detailhandel

Reparatiebedrijf gebruiksgoederen

12

Bouwinstallatiebedrijf

Hotel, restaurant, café e.d.

$\angle B O$ technisch: voortijdige schoolverlaters

Detailhandel

Bouwnijverheid

Reparatiebedrijf gebruiksgoederen

Bouwinstallatiebedrijf

Hotel, restaurant, café e.d.

MBO technisch: gediplomeerde schoolverlaters

Detailhandel

Bouwnijverheid

Bouwinstallatiebedrijf

Zakelijke dienstverlening

Machine-industrie

Groothandel

Reparatiebedrijf gebruiksgoederen

MBO technisch: voortijdige schoolverlaters

Detailhandel

Bouwnijverheid

Bouwinstallatiebedrijf

Reparatiebedrijf gebruiksgoederen

Hotel, restaurant, café e.d.

Ten aanzien van de aansluiting van het niveau van de opleiding en het niveau van de functie waarin men werkzaam is moet worden opgemerkt dat onderbenutting slechts eenduidig kan worden bepaald voor schoolverlaters die hun opleiding met een diploma hebben verlaten. Met betrekking tot de voortijdige schoolverlaters is het namelijk niet duidelijk of de vorige afgemaakte opleiding, ofwel het aantal gevolgde schooljaren van de afgebroken opleiding bepaalt of er sprake is van onder- of overbenutting. Derhalve is in tabel $\mathbf{5 . 5}$ alleen het vereiste opleidingsniveau voor de functie waarin de gediplomeerde en de voortijdige schoolverlaters ten 
tijde van de enquête werkzaam zijn, weergegeven. Door te kijken naar het opleidingsniveau dat vereist is voor de functie die de voortijdige schoolverlaters ongeveer én jaar na het afbreken van de opleiding uitoefenen, kan bijvoorbeeld worden nagegaan of voortijdige MBOschoolverlaters voornamelijk banen hebben waarvoor een LBO-opleiding werd vereist of dat ze toch voornamelijk in functies op MBO-niveau werkzaam zijn.

Tabel 5.5. Vereiste opleidingsniveau voor de functie die men uitoefent per opleidingstype

\begin{tabular}{lccccccc}
\hline & geen opleiding/ & & leerlingwezen/ & & HAVO/ & & \\
& basis onderwijs & LBO & KMBO & MAVO & VWO & MBO & HBO \\
Opleidingstype & $\%$ & $\%$ & $\%$ & $\%$ & $\%$ & $\%$ & $\%$ \\
\hline
\end{tabular}

Gediplomeerde schoolverlaters

\begin{tabular}{llllllrr} 
LBO technisch & 16 & 67 & 14 & 1 & 0 & 2 & 0 \\
MBO technisch & 11 & 12 & 13 & 4 & 1 & 58 & 1 \\
& & & & & & & \\
Voortijdige schoolverlaters & & & & & & \\
LBO technisch & 32 & 51 & 10 & 3 & 1 & 0 \\
MBO technisch & 31 & 26 & 12 & 14 & 1 & 15 & 0 \\
\hline
\end{tabular}

Bron: RUBS 1992/ROA

Ook de vakrichting die is vereist voor de functie die deze schoolverlaters uitoefenen, kan inzicht verschaffen in de marktpositie die de voortijdige schoolverlaters op de arbeidsmarkt ondervinden. Tabel 5.6 laat zien dat het merendeel van de ongediplomeerde schoolverlaters werkzaam is op een breed toegankelijk arbeidsmarktsegment. Dit betekent dat men te maken heeft met concurrentie vanuit andere opleidingen. Daar staat echter tegenover dat een derde van de ongediplomeerde schoolverlaters wel werkzaam is binnen de vakdeelmarkten waarvoor de opleiding die men voortijdig heeft afgebroken beoogt op te leiden.

Tabel 5.6. Vereiste vakrichting voor de functie die men uitoefent per opleidingstype

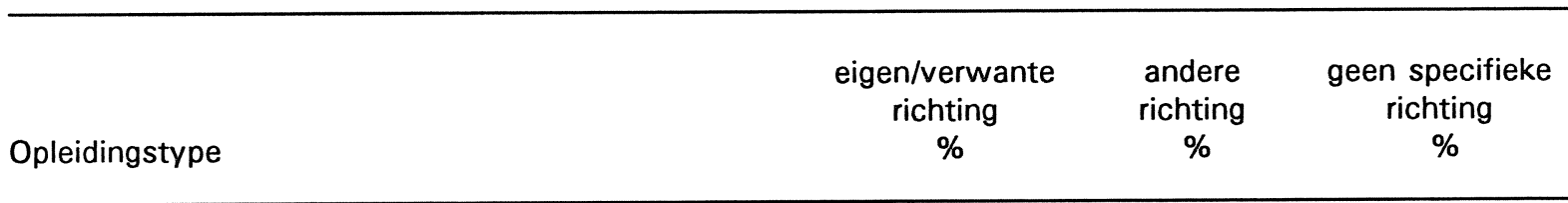

Gediplomeerde schoolverlaters

$\begin{array}{lllll}\text { LBO technisch } & 50 & 3 & 47 \\ \text { MBO technisch } & 56 & 3 & 40 \\ \text { Voortijdige schoolverlaters } & & & \\ \text { LBO technisch } & 33 & 3 & 64 \\ \text { MBO technisch } & 32 & 4 & 64\end{array}$


Tabel 5.7. Netto uurloon per opleidingstype

\begin{tabular}{llc} 
Opleidingstype & $\begin{array}{l}\text { gemiddelde } \\
\text { (in guldens) }\end{array}$ & $\begin{array}{c}\text { standaard- } \\
\text { deviatie }\end{array}$ \\
\hline
\end{tabular}

Gediplomeerde schoolverlaters

$\begin{array}{llrr}\text { LBO } & \text { technisch } & 6,00 & 1,82 \\ \text { MBO } & \text { technisch } & 9,32 & 2,65\end{array}$

Voortijdige schoolverlaters

$\begin{array}{lrrr}\text { LBO } & \text { technisch } & 5,87 & 1,65 \\ \text { MBO } & 7,82 & 2,77\end{array}$

Bron: RUBS 1992/ROA

Zoals reeds in hoofdstuk 3 is opgemerkt kan het loon (zie tabel 5.7) een indicatie van de situatie op de arbeidsmarkt geven, waarbij een hoog loon op een krappe arbeidsmarkt kan duiden. Aangezien mag worden verwacht dat de voortijdige schoolverlaters de meest kwetsbare positie innemen in het geval van een economische recessie verschaft het loon van de voortijdige schoolverlaters belangrijke informatie, waarbij de verschillen tussen gediplomeerde en voortijdige schoolverlaters zullen toenemen bij een ruime arbeidsmarkt. Uit tabel 5.7 blijkt dat met name bij de ongediplomeerde MBO-schoolverlaters het beloningsverschil met de gediplomeerde schoolverlaters aanzienlijk is. Daarbij moet echter worden bedacht dat voortijdige schoolverlaters in het algemeen jonger zijn dan de gediplomeerden van dezelfde opleiding. Dit maakt deze indicator minder geschikt om de arbeidsmarktpositie van voortijdige schoolverlaters met de marktpositie van gediplomeerden te vergelijken. Om deze reden is voor de voortijdige schoolverlaters ook niet bepaald welk percentage een relatief laag inkomen verdient.

Tabel 5.8. Deelname aan aanvullende cursussen en deeltijd opleidingen per opleidingstype

\begin{tabular}{lcc}
\hline & inclusief & $\begin{array}{c}\text { exclusief } \\
\text { leerlingwezen } \\
\text { Opleidingstype }\end{array}$ \\
\hline
\end{tabular}

\section{Gediplomeerde schoolverlaters}

$\begin{array}{lllr}\text { LBO } & \text { technisch } & 76 & 13 \\ \text { MBO } & \text { technisch } & 41 & 28\end{array}$

Voortijdige schoolverlaters

LBO technisch

Bron: RUBS 1992/ROA

Met betrekking tot het gevolgde aanvullend onderwijs moet worden opgemerkt dat dit voor de voortijdige schoolverlaters een andere functie kan vervullen dan voor de gediplomeerde schoolverlaters. Via aanvullende opleidingen trachten de ongediplomeerde schoolverlaters 
wellicht de ontbrekende kwalificaties te behalen die de gediplomeerden in principe reeds bezitten. Daarentegen gaat het bij de gediplomeerden in de eerste plaats om het verwerven van extra kwalificaties. Tabel 5.8 laat zien dat een aanzienlijk deel van de voortijdige schoolverlaters inderdaad de ontbrekende kwalificaties via het leerlingwezen of in-service onderwijs alsnog tracht te behalen.

Tabel 5.9. Soort aanstelling per opleidingstype

\begin{tabular}{lccc}
\hline Opleidingstype & $\begin{array}{c}\text { zelfstandigen } \\
\%\end{array}$ & $\begin{array}{c}\text { in loondienst } \\
\%\end{array}$ & $\begin{array}{c}\text { vaste baan } \\
\%\end{array}$ \\
\hline Gediplomeerde schoolverlaters & & & \\
LBO technisch & 1 & 98 & 20 \\
MBO technisch & 3 & 96 & 66 \\
Voortijdige schoolverlaters & & & \\
LBO technisch & 2 & 96 & 30 \\
MBO technisch & 2 & 96 & 50 \\
\hline
\end{tabular}

Bron: RUBS 1992/ROA

Tot slot nog een aantal kenmerken die een aanvulling kunnen vormen bij de hierboven reeds genoemde indicatoren die de kwetsbaarheid van de arbeidsmarktpositie van de voortijdige schoolverlaters weergeven. Tabel $\mathbf{5 . 9}$ geeft een beeld van de soort aanstelling die de voortijdige schoolverlaters hebben. Alleen met betrekking tot het percentage werkenden met een vaste aanstelling blijkt dat de ongediplomeerde LBO- en MBO-ers aanmerkelijk achterblijven bij de gediplomeerde LBO- en MBO-ers.

Tabel 5.10. Wekelijkse arbeidsduur per opleidingstype

Opleidingstype

Gediplomeerde schoolverlaters

LBO technisch 70

MBO technisch

Voortijdige schoolverlaters

LBO technisch

MBO technisch

39

Bron: RUBS 1992/ROA

Tabel 5.10 geeft het percentage in deeltijd werkende voortijdige schoolverlaters aan. Net als bij de gediplomeerde schoolverlaters kan het grote aandeel dat een part-time baan heeft mogelijk mede worden veroorzaakt door het relatief grote percentage dat alsnog probeert de benodigde 
kwalificaties te behalen via het leerlingwezen of in-service onderwijs. Opvallend is echter dat het percentage voortijdige schoolverlaters van het LBO dat in deeltijd werkt lager is dan bij de gediplomeerden van het LBO technisch.

Tot slot kan de grootte van de organisatie waarin de voortijdige schoolverlaters terechtkomen mogelijk eveneens enig inzicht verschaffen over de verschillen in de positie op de arbeidsmarkt tussen de voortijdige en de gediplomeerde schoolverlaters.

Tabel 5.11. Grootte van de organisatie waarin de schoolverlaters werkzaam zijn

\begin{tabular}{lcccc}
\hline & & & & \\
& $1-9$ & $10-49$ & $50-99$ & 100 \\
Opleidingstype & personen & personen & personen & personen \\
$\%$ & $\%$ & $\%$ & $\%$
\end{tabular}

Gediplomeerde schoolverlaters

$\begin{array}{llllrr}\text { LBO } & \text { technisch } & 34 & 41 & 11 & 14 \\ \text { MBO } & \text { technisch } & 29 & 35 & 10 & 26\end{array}$

Voortijdige schoolverlaters

$\begin{array}{lllrrr}\text { LBO } & \text { technisch } & 32 & 42 & 9 & 16 \\ \text { MBO } & \text { technisch } & 29 & 34 & 12 & 25\end{array}$

Bron: RUBS 1992/ROA

In principe is het ook mogelijk om ook voor de voortijdige schoolverlaters met behulp van samengestelde indicatoren de verschillende facetten van de aansluitingsproblematiek tussen onderwijs en arbeidsmarkt in beeld te brengen. Daarbij kan met name worden gedacht aan de in paragraaf 4.3 gepresenteerde penta- en heptagrammen. Eveneens zou, zoals in paragraaf 4.4 werd aangegeven, met behulp van multivariate analyses kunnen worden nagegaan welk effect het al dan niet bepalen van een bepaald diploma heeft op bijvoorbeeld de kans op werk voor een individu met bepaalde achtergrondkenmerken. 


\section{BESLUIT}

\subsection{Belangrijkste uitkomsten}

In dit slothoofdstuk zullen eerst de belangrijkste uitkomsten van dit verkennende onderzoek kort de revue passeren. Daarna zal in paragraaf 6.2 nader worden ingegaan op de wenselijkheid van eventuele verdere vervolgonderzoeken met betrekking tot de inpassing van schoolverlatersinformatie in het informatiesysteem onderwijs-arbeidsmarkt.

In hoofdstuk 3 van het rapport zijn verschillende indicatoren naar voren gebracht die een belangrijke verbetering betekenen ten opzichte van de huidige indicatoren van het informatiesysteem. Daarbij kan worden gedacht aan:

- $\quad$ werkloosheidspercentage;

- $\quad$ percentage onderbenutting;

- $\quad$ percentage dat als zelfstandige werkt;

- $\quad$ percentage dat deeltijd werk verricht;

- $\quad$ uitwijkmogelijkheden naar andere beroepen;

- $\quad$ uitwijkmogelijkheden naar andere branches;

- $\quad$ conjunctuurgevoeligheid van de werkgelegenheid.

De beide schoolverlatersonderzoeken maken het vooral mogelijk om deze indicatoren te verbeteren door het lagere aggregatieniveau waarop de indicatoren kunnen worden gegenereerd. In plaats van de 35 opleidingstypen op AVO, LBO, MBO en HBO-niveau die tot op heden in het informatiesysteem onderwijs-arbeidsmarkt worden onderscheiden, kan de schoolverlatersinformatie worden verbijzonderd naar maar liefst circa 100 specifieke opleidingsrichtingen. Op deze wijze kan op een, zowel voor de studie- en beroepskeuzevoorlichting als voor verschillende andere beleidsdoeleinden, veel relevanter niveau de aansluitingsproblematiek tussen onderwijs en arbeidsmarkt in beeld worden gebracht. Bij de risico-indicatoren die aangeven in welke mate schoolverlaters met een bepaalde opleidingsachtergrond beschikken over uitwijkmogelijkheden op de arbeidsmarkt naar branche en beroep, betekent het lagere aggregatieniveau waarop deze indicatoren nu kunnen worden berekend, ook dat de gepresenteerde indicatoren veel beter tegemoet komen aan de intentie van deze risicoindicatoren. Immers, bij het bepalen van deze indicatoren op een hoger aggregatieniveau kunnen er belangrijke vertekeningen optreden in de mate waarin er uitwijkmogelijkheden worden vastgesteld vanwege de heterogeniteit van de onderliggende opleidingen.

Ook maken de beide schoolverlatersenquêtes het mogelijk de mate van onderbenutting van het gevolgde opleidingsniveau meer adequaat in beeld te brengen. Doordat ook gevraagd wordt naar het minimaal vereiste opleidingsniveau van de functie die men uitoefent, hoeft geen gebruik gemaakt te worden van de tot op heden gehanteerde enigszins verouderde functieniveautypering op 4-digit beroepsniveau. Op deze wijze kan rekening worden gehouden met de eventuele niveauverschillen tussen de functies die tot hetzelfde beroep worden gerekend. 
$-56-$

Daarnaast zijn in de hoofdstukken 3 en 4 indicatoren gepresenteerd die een waardevolle aanvulling kunnen betekenen ten aanzien van de huidige informatie. Daarbij komen de volgende (soms samengestelde) indicatoren in aanmerking:

- duur van de intredewerkloosheid;

- $\quad$ aansluiting tussen opleiding en werk (al dan niet vereiste specifieke vakrichting);

- inkomen;

- mate waarin schoolverlaters aan aanvullende cursussen en deeltijd opleidingen deelnemen;

- $\quad$ aard van het dienstverband (zelfstandigen, loondienst, vaste baan);

- $\quad$ percentage deeltijd werk;

- grootte van organisaties waarin schoolverlaters werkzaam zijn;

- $\quad$ percentage leidinggevenden;

- maat waarin schoolverlaters van verschillende opleidingen elkaar beconcurreren;

- combinaties van indicatoren die op basis van meerdere aspecten van de aansluiting onderwijs-arbeidsmarkt informatie geven over de directe aansluiting tussen het initiële onderwijs en de arbeidsmarkt: de penta- en heptagrammen geven respectievelijk een algeheel beeld van de arbeidsmarktpositie en van de actuele aansluiting, de combinatie van de conjunctuurgevoeligheid en de spreidingsindicatoren die een indicatie geven van de risico's die de schoolverlaters op de arbeidsmarkt ondervinden en de samengestelde indicator op basis van de factoranalyse die de mismatch in de overgang van onderwijs naar de arbeidsmarkt aangeeft;

- het netto-effect (met betrekking tot de kans op werk of het inkomen) van het volgen van een bepaalde opleiding voor individuele schoolverlaters of een bepaalde groep schoolverlaters;

- informatie over de positie van voortijdige schoolverlaters/drop-outs.

De informatie over de vakrichting die werd vereist voor de functie die men uitoefent op het moment van enquêteren, maakt het mogelijk een typering te geven van het arbeidsmarktsegment waarop de schoolverlaters van een bepaalde opleidingsrichting terechtkomen. Daarbij is met name het onderscheid dat gemaakt kan worden tussen enerzijds de breed toegankelijke arbeidsmarktsegmenten, waarop men concurrentie zal ondervinden van verschillende andere opleidingsrichtingen, en anderzijds de zogenaamde 'vakdeelmarkt' waarvoor de desbetreffende opleiding beoogt op te leiden, van groot belang. Zowel de aard van het dienstverband als het verdiende inkomen zijn belangrijke indicatoren van de arbeidsmarktpositie van een bepaalde opleiding, die ook een waardevolle rol kunnen spelen bij het presteren van samengestelde indicatoren.

De in hoofdstuk 4 weergegeven (1) pentagrammen van de verschillende aspecten van de marktpositie van schoolverlaters in brede zin, (2) de heptagrammen met betrekking tot de actuele arbeidsmarktpositie van schoolverlaters, (3) de algehele typering van de arbeidsmarktrisico's van de verschillende opleidingen en (4) de samengestelde indicatoren van de mismatch in de directe aansluiting tussen onderwijs en arbeidsmarkt, laten zien op welke wijze een samenvattend beeld kan worden gegeven van de aansluitingsproblematiek tussen 
onderwijs en arbeidsmarkt, zonder daarbij te vervallen in een eenzijdige typering van de mismatch of arbeidsmarktpositie op basis van een enkel aspect van de aansluitingsproblematiek. In aansluiting daarop bieden multivariate analyses de mogelijkheid om de betekenis van het volgen van een bepaalde opleiding voor een individu of een groep van individuen met bepaalde achtergrondkenmerken in beeld te brengen.

Erg waardevol is ook dat met behulp van de RUBS-enquête eventuele verschillen in de arbeidsmarktpositie tussen gediplomeerden en ongediplomeerden c.q. 'voortijdige schoolverlaters' in beeld kunnen worden gebracht. Voor zover zinvol kan dit op basis van alle in hoofdstuk 3 gepresenteerde indicatoren. Bovendien kan nader worden aangegeven in welke mate voortijdige schoolverlaters via het leerlingwezen of een in-service opleiding alsnog een startkwalificatie proberen te bemachtigen. Wel moet worden opgemerkt dat de respons van ongediplomeerde schoolverlaters in de RUBS-enquête 1992 zeer laag was, waardoor de indicatoren met de nodige voorzichtigheid dienen te worden geïnterpreteerd. Ook moet worden bedacht dat het kan gaan om een zeer heterogene groep met betrekking tot het leerjaar waarin men de opleiding voortijdig heeft verlaten. Daarnaast geeft de informatie over de aansluiting tussen onderwijs en arbeidsmarkt direct na het beëindigen van de opleiding geen informatie over de lange-termijn stabiliteit van de arbeidsmarktpositie van de schoolverlaters.

\subsection{Mogelijke vervolgtrajecten}

Naast de concrete inpassing van de momenteel beschikbare schoolverlatersinformatie in het informatiesysteem onderwijs-arbeidsmarkt bestaat er een groot aantal mogelijkheden voor verdere ontwikkeltrajecten en vervolgonderzoeken. Deze mogelijke vervolgonderzoeken kunnen in drie categorieën worden ingedeeld:

1. De op basis van de huidige schoolverlatersenquêtes mogelijke verdere ontwikkeltrajecten met betrekking tot arbeidsmarktindicatoren en -prognoses.

2. De verdere mogelijkheden bij een schaalvergroting van de huidige schoolverlatersenquêtes of het opzetten van additionele meetinstrumenten.

3. Het ontwikkelen van informatieprodukten voor andere gebruiksdoelen.

Hieronder zullen deze drie categorieën achtereenvolgens nader worden ingevuld.

\section{Ontwikkeltrajecten op basis van de huidige informatie}

In de eerste plaats is het op basis van de huidige vragenlijsten mogelijk om meer informatie te genereren over:

- de (aard van de) door werkenden en werklozen gevolgde cursussen;

- de baanzoekduren van de schoolverlaters;

- de concurrentie van andere opleidingen.

In de enquêtes wordt de vraag gesteld of men een aanvullende opleiding of cursus volgt, en zo ja, welke opleiding of cursus dat is. Bovendien wordt, in de RUBS-enquête, een meerkeuzevraag 
gesteld naar de reden voor het volgen van de cursus. Tot op heden is in de RUBS-enquête de naam van de cursus die men volgt slechts alfanumeriek ingevoerd, mede vanwege het ontbreken van een adequaat indelingsschema. Indien de gevolgde cursussen volgens een dergelijke indeling geclassificeerd zouden worden, zou waardevolle informatie kunnen worden verkregen over de aard c.q. de richting van de bij-, her-, of omscholing die schoolverlaters met een bepaalde opleidingsachtergrond volgen.

Vanaf 1993 is het ook mogelijk om de zogenaamde baanzoekduren van schoolverlaters in beeld te brengen (zie Berkhout en Mot, 1992). Deze baanzoekduur heeft betrekking op de lengte van de zoekperiode voor het vinden van een baan. In beginsel kan de zoekduur hier ook worden bepaald tot een baan die voldoet aan bepaalde eisen (bijvoorbeeld vaste aanstelling, werk waarvoor de gevolgde opleiding is vereist etc.). De factoranalyse van hoofdstuk 4 heeft uitgewezen dat de kans op werk een dimensie vertegenwoordigd die onafhankelijk is van de kwaliteit van het werk. Door naast de zoekduur tot een baan ook de zoekduur tot een baan van een bepaalde kwaliteit te schatten kan een beter inzicht worden verkregen in de feitelijke arbeidsmarktpositie van schoolverlaters.

Door gebruik te maken van de mate waarin opleidingen van elkaar verschillen in het soort beroepen waar men terechtkomt, kan een spreidingscoëfficiënt worden berekend, die de mate van concurrentie tussen opleidingen aangeeft. Voor een consistente maatstaf is echter informatie nodig over de volle breedte van de arbeidsmarkt. Daar momenteel gegevens ontbreken over afgestudeerden van het WO kan dit aspect vooralsnog alleen op basis van de minder gedetailleerde EBB-gegevens worden opgenomen in het Informatiesysteem onderwijsarbeidsmarkt.

In de tweede plaats biedt de RUBS- en HBO-schoolverlatersinformatie de mogelijkheid om een eerste indicatie te krijgen van het (netto) financiële rendement van het volgen van bepaalde opleidingen. Daarbij kan ook gekeken worden naar het effect van de gevolgde leerroute en naar het financiële rendement van de opleiding voor een specifieke groep schoolverlaters.

In dit kader kan er ook nog worden gewezen op de mogelijkheden om andere arbeidsmarktindicatoren te ontwikkelen die niet primair gericht zijn op het in beeld brengen van de arbeidsmarktpositie van de schoolverlaters van een bepaalde opleidingsrichting in het algemeen. Zo zouden in principe ook indicatoren kunnen worden gegenereerd die inzicht geven in de effecten van het volgen van een bepaalde opleiding op de arbeidsmarktkansen van individuele schoolverlaters, die gekenmerkt worden door bepaalde achtergrondkenmerken. Op basis van multivariate analyses die aan dergelijke indicatoren ten grondslag liggen, kan bijvoorbeeld het netto-effect van het volgen van een bepaalde opleiding voor vrouwen, of het arbeidsmarkteffect van bepaalde inefficiënte leerroutes in beeld worden gebracht.

In de derde plaats vormen de werkgelegenheidsprognoses een belangrijk aandachtspunt bij de inpassing van schoolverlatersinformatie in het ROA-informatiesysteem onderwijs-arbeidsmarkt. Als aanvulling op de huidige uitbreidingsvraagprognoses bieden de schoolverlatersenquêtes de 
volgende drie mogelijkheden:

- het opstellen van specifieke werkgelegenheidsprognoses voor schoolverlaters;

- $\quad$ het verbijzonderen van de werkgelegenheidsprognoses van de ROA-opleidingstypen naar opleidingsrichting;

- het inpassen van bepaalde schoolverlatersgegevens in de huidige werkgelegenheidsprognoses, zoals bijvoorbeeld inkomen.

Bij het opstellen van specifieke werkgelegenheidsprognoses voor schoolverlaters kan vooralsnog het beste een extra stap worden toegevoegd aan het huidige prognosemodel. Deze aanpak zorgt ervoor dat de resultaten van de uitbreidingsvraagprognoses voor schoolverlaters aansluiten bij de prognoses voor het informatiesysteem. Bovendien maakt het de prognoseresultaten vrij robuust. Aangezien de RUBS-enquête pas sinds 1992 een landelijk karakter draagt en de HBO-Monitor in 1991 is gestart bieden de schoolverlatersenquêtes bovendien op dit moment nog te weinig mogelijkheden om geheel nieuwe uitbreidingsvraagprognoses voor schoolverlaters te construeren. Bij een langdurige voortzetting van de schoolverlatersprojecten kan dit echter wellicht wel tot de mogelijkheden gaan behoren.

Vanwege de verregaande mate van detaillering die op basis van de RUBS- en HBO-enquêtes kan worden bereikt ten aanzien van de opleidingen kan er ook worden gedacht aan het verbijzonderen van de werkgelegenheidsprognoses per ROA-opleidingstype naar meer specifieke prognoses verbijzonderd naar opleidingsrichting. Op basis van de EBB-gegevens wordt momenteel reeds voor een aantal grote opleidingscategorieën, bijvoorbeeld het technisch onderwijs, onderzocht in hoeverre een verdere mate van detaillering kan worden toegepast voor de gegevens die in het huidige informatiesysteem zijn opgenomen (zie Willems, 1993). Daar de schoolverlatersenquêtes, mede door het relatief grote aantal waarnemingen op het lagere aggregatieniveau, te maken hebben met minder stringente publikatierestricties dan de door het CBS opgelegde bepalingen ten aanzien van de EBB, kunnen de RUBS- en HBO-gegevens hierop een belangrijke bron van aanvullende data leveren.

De laatstgenoemde mogelijkheid betreft het gebruiken van gegevens die in de schoolverlatersenquêtes zijn opgenomen als verklarende variabelen in het uitbreidingsvraagmodel. Daarbij kan worden gedacht aan het inkomen dat de schoolverlaters verdienen. Momenteel wordt in het prognosemodel voor de werkgelegenheidsontwikkeling naar opleiding rekening gehouden met de huidige werkloosheid (zie Borghans en Heijke, 1993). De benodigde gegevens hiervoor zouden ook aan de schoolverlatersenquêtes kunnen worden ontleend, hetgeen een steeds grotere noodzaak wordt indien de BZB-bestanden voor langere tijd niet beschikbaar zullen zijn.

Tot nog toe beperken de prognoses voor wat betreft de arbeidsmarktperspectieven van schoolverlaters zich tot de Indicator Toekomstige Arbeidsmarktsituatie (ITA), die een indicatie geeft van de schaarsteverhoudingen in de nabije toekomst. Een hoge ITA betekent echter niet per sé dat de schoolverlaters die deze opleiding volgen een hoge kans op werkloosheid zullen hebben. De ongunstige arbeidsmarktperspectieven zouden ook tot uiting kunnen komen in de hoogte van het loon, de baanzekerheid en de omvang en het niveau van de baan die men kan 
$-60-$

krijgen. Om beter de consequenties van de verwachte tekorten en overschotten op de arbeidsmarkt te kunnen beschrijven, maar ook om de leerling, die voor een studiekeuzebeslissing staat, te confronteren met deze verschillende dimensies van het arbeidsmarktperspectief, zou onderzoek gedaan kunnen worden naar de wijze waarop de voorspelde schaarsteverhoudingen op de arbeidsmarkt zich bij de verschillende studierichtingen waarschijnlijk zullen manifesteren. Daarbij zal een relatie worden gelegd tussen de arbeidsmarktprognoses en de indicatoren met betrekking tot de uitwijkmogelijkheden, onderbenutting e.d. De RUBS- en de HBO-schoolverlatersenquêtes bieden hiertoe goede mogelijkheden.

\section{Schaalvergroting enquêtes en aanvullende meetinstrumenten}

De bovenstaande mogelijke aandachtspunten voor vervolgonderzoeken met betrekking tot de inpassing van de RUBS- en HBO-Monitor gegevens in het informatiesysteem onderwijsarbeidsmarkt hebben allemaal betrekking op de op dit moment beschikbare informatie. Om een meer volledig overzicht te kunnen krijgen van de mogelijke verdere ontwikkelingen van het informatiesysteem op dit punt, is het goed om een aantal uitbreidingsmogelijkheden van de dataverzameling kort de revue te laten passeren.

In de eerste plaats kan daarbij worden gedacht aan het vergroten van de steekproef van de RUBS-enquête. Op deze wijze zou beter kunnen worden ingespeeld op de behoefte om voor het studie- en beroepskeuzevoorlichtingsbeleid en andere beleidsdoeleinden ook op regionaal niveau op een relatief laag aggregatieniveau arbeidsmarktinformatie naar opleiding te kunnen genereren. Overigens bestaat ook nog steeds de mogelijkheid om, als implementatie van het begin 1992 afgesloten ontwikkeltraject, op provinciaal en/of RBA-niveau soortgelijke arbeidsmarktinformatie naar opleiding en/of beroep te presenteren als momenteel op landelijk niveau wordt opgeleverd (zie Berendsen, De Grip, Wieling en Willems, 1992a, 1992b, 1992c), te weten:

- $\quad$ aantal werkenden naar beroepsklasse en opleidingstype;

- $\quad$ indicator vergrijzing (en/of ontgroening) naar beroepsklasse en opleidingstype;

- $\quad$ werkloosheidspercentage naar opleidingstype ${ }^{28}$;

- prognose van de uitbreidingsvraag, vervangingsvraag en baanopeningen naar beroepsklasse en opleidingstype;

- $\quad$ prognose van de instroom van schoolverlaters per opleidingstype;

- $\quad$ typering van de toekomstige arbeidsmarktsituatie naar opleidingstype.

Indien er op regionaal niveau voldoende schoolverlatersinformatie beschikbaar zou zijn, bestaat tevens de mogelijkheid deze informatie te combineren met de op basis van de EBB te genereren arbeidsmarktinformatie.

Een tweede, zeer belangrijke, uitbreiding van de beschikbare schoolverlatersinformatie betreft

28. Indien weer beschikt kan worden over de cijfers van de Arbeidsvoorzieningsorganisatie. 
het opvullen van de huidige lacune in de schoolverlatersinformatie: de informatie over de afgestudeerden van het universitaire onderwijs. Als gevolg van deze lacune is het vooralsnog onmogelijk voor het WO dezelfde gedetailleerde arbeidsmarktinformatie te kunnen verstrekken als voor het HBO. In principe zou voor het WO dezelfde onderzoeksopzet kunnen worden gevolgd als bij de HBO-Monitor. Indien een dergelijke aanpak niet haalbaar blijkt te zijn, zou ook kunnen worden overwogen, om evenals bij de RUBS-enquête een landelijke 'rompenquête' op te zetten, waar de universiteiten bij zouden kunnen aanhaken om een volledige beeld te kunnen krijgen van de arbeidsmarktpositie van hun eigen afgestudeerden.

Bovendien zou een enquête onder de afgestudeerden van het WO het mogelijk maken om niet alleen de arbeidsmarktinformatie naar opleiding te verbijzonderen, maar ook de arbeidsmarktinformatie voor schoolverlaters naar beroep en bedrijfssector. Hiervoor is immers een monitoring van de schoolverlaters over de volle breedte van het onderwijs vereist. Een beperking van de informatie naar beroep en bedrijfssector is in dat geval nog wel dat alleen de initiële opleidingskwalificaties van de werkenden in beeld kunnen worden gebracht ${ }^{29}$.

Een derde waardevolle uitbreidingsmogelijkheid van de beschikbare informatie zou kunnen worden gerealiseerd door het opzetten van herhalingsmetingen naar de bestemming van de schoolverlaters 5, 10 en/of 15 jaar na het moment dat ze hun school verlieten. Eventueel zou een dergelijke meting alleen betrekking kunnen hebben op de schoolverlaters die daadwerkelijk het reguliere dagonderwijs verlieten. Dergelijke herhalingsmetingen maken het mogelijk meer inzicht te krijgen in de latere jaren van de beroepsloopbaan van jongeren. Met name is het van belang om inzicht te krijgen in de beginperiode van de beroepsloopbanen, omdat deze periode in belangrijke mate bepalend is voor het verdere verloop van de beroepsloopbaan. Ook kan op deze wijze beter inzicht worden verkregen in het externe rendement van de gevolgde opleiding, gemeten in inkomenstermen.

\section{Informatieprodukten voor andere gebruiksdoelen}

Tot op heden is de inhoud van het informatiesysteem onderwijs-arbeidsmarkt sterk gericht op de gebruikswaarde voor het onderwijs- en arbeidsmarktbeleid in het algemeen en het studie- en beroepskeuzevoorlichtingsbeleid in het bijzonder. Uit het verkennende marktonderzoek naar de gebruikswaarde van het ROA-rapport De arbeidsmarkt naar opleiding en beroep (zie Nieuwland en De Grip, 1993) kwam o.a. naar voren dat er onder verschillende gebruikersgroepen belangstelling is voor een diskette met de ROA-arbeidsmarktinformatie. Presentatie in de vorm van spreadsheets hebben daarbij de voorkeur. De diskette wil men vooral gebruiken om bij te blijven met de ontwikkelingen op de externe arbeidsmarkt, waarbij zowel de respondenten uit het bedrijfsleven als uit de Arbeidsvoorzieningsorganisatie de informatie ook zouden willen gebruiken voor eigen onderzoek. Het spreekt voor zich dat de gebruikswaarde van een dergelijke

29. Overigens exclusief de in het kader van het leerlingwezen en in-service opleidingen behaalde diploma's. In het RUBS-project van 1994 wordt trouwens het Beroepsbegeleidend Onderwijs (BBO) betrokken. 
diskette nog in belangrijke mate zou kunnen toenemen, wanneer de huidige inhoud van het informatiesysteem zou kunnen worden gecombineerd met de informatie uit de beide schoolverlatersenquêtes.

Ook zou kunnen worden overwogen een informatieprodukt, mogelijk eveneens in de vorm van een diskette, te ontwikkelen specifiek gericht op de arbeidsvoorzieningsorganisatie. Een dergelijk produkt zou kunnen aansluiten bij de uit het marktonderzoek gebleken behoefte onder respondenten uit de Arbeidsvoorzieningsorganisatie aan arbeidsmarktprognoses van de arbeidsmarktsituatie naar beroep en opleiding over 1 à 2 jaar. Ook de RUBS- en HBO-informatie zou in een dergelijk produkt kunnen worden ingepast. In dit verband zou overigens een goede afstemming moeten plaatsvinden op het informatieprodukt dat momenteel door het ROA op basis van de RUBS-gegevens in opdracht van het LDC voor RBA's wordt ontwikkeld. 


\section{LITERATUUR}

Beekman, Th.B.J., A. de Grip (1991), Werkloosheidsindicatoren voor schoolverlaters, ROA-RM1991/1, Maastricht.

Berendsen, H., A. de Grip, M.H. Wieling, E.J.T.A. Willems (1992a), Regionale arbeidsmarktinformatie naar opleiding en beroep: Een verkenning vanuit het ROA-informatiesysteem onderwijs-arbeidsmarkt, ROA-R-1992/2, Maastricht.

Berendsen, H., A. de Grip, M.H. Wieling, E.J.T.A. Willems (1992b), Arbeidsmarktinformatie naar opleiding en beroep voor de provincie Noord-Holland, ROA-R-1992/3, Maastricht.

Berendsen, H., A. de Grip, M.H. Wieling, E.J.T.A. Willems (1992c), Arbeidsmarktinformatie naar opleiding en beroep voor de provincie Friesland: Tabellenoverzicht, ROA-W-1992/4, Maastricht.

Berkhout, P.H.G., E.S. Mot (1992), De arbeidsmarktrelevantie van opleidingen, OAV-rapport 92008, Arbeidsvoorziening, Rijswijk.

Borghans, L. (1992), A Histo-Topographic Map of the Dutch University Studies, ROA-W1992/5E, Maastricht.

Borghans, L., J.A.M. Heijke (1993), Forecasting the Educational Structure of Occupations: $A$ Manpower Requirement Approach with Substitution, ROA-RM-1993/2E, Maastricht.

CBA (1991), Schoolverlatersbrief 1991, Rijswijk.

CBS (1993a), Enquête beroepsbevolking 1992, Voorburg/Heerlen.

CBS (1993b), Standaard beroepenclassificatie 1992, SDU-Uitgeverij, 's-Gravenhage.

Grip, A. de, L.F.M. Groot, J.A.M. Heijke, E.J.T.A. Willems (1990), De aans/uiting tussen beroepen en functies en de relatie met scholings- en mobiliteitsprocessen, OSA-werkdocument W80, 's-Gravenhage.

Grip, A. de, J.A.M. Heijke (1989), Het flexibiliteitspotentieel van universitaire studierichtingen, Tijdschrift voor Arbeidsvraagstukken, vol. 5, p. 220-238.

Grip, A. de, J.A.M. Heijke, E.J.T.A. Willems (1992), Scholing en mobiliteit, Maandschrift Economie, vol. 56, p. 131-144.

Grip, A. de, R.K.W. van der Velden, M.H. Wieling (1991), Indicatoren aans/uiting onderwijsarbeidsmarkt MDGO: Enkele arbeidsmarktindicatoren op basis van de RUBS-data, ROA-R1991/2, Maastricht.

Grip, A. de, R.K.W. van der Velden, M.H. Wieling (1993), De arbeidsmarktpositie van MDGOschoolverlaters, Tijdschrift voor Arbeidsvraagstukken, jrg. 9, nr. 3, blz. 241-252.

Hoof, J.J. van, J. Dronkers (1980), Onderwijs en arbeidsmarkt, Sociologische monografieën, Van Loghum Slaterus, Deventer.

Huijgen, F (1989), De kwalitatieve structuur van de werkgelegenheid in Nederland; Deel III: Bevolking in loondienst en functiestructuur in 1977 en 1985, OSA-voorstudie V33, 'sGravenhage. 
Laarhoven, P. van, S. Waslander (1990), Uitstroom en bestemming van MDGO-schoolverlaters: Een landelijke rapportage over het RUBS-project in 1989, RION, Groningen.

LDC (1993), Kansen op werk: Arbeidsmarktperspectieven van opleidingen en beroepen, Meppel.

Lodder, B.J.H., G.W.M. Ramaekers, R.K.W. van der Velden (1991), De arbeidsmarktpositie van schoolverlaters van het economisch en administratief (K)MBO: RUBS '91, ROA-R-1991/11, Maastricht.

Loo, P.J.E. van de, G.W.M. Ramaekers, R.K.W. van der Velden (1992a), De arbeidsmarktpositie van afgestudeerden van het hoger pedagogisch onderwijs 1991, HBO-Raad, Den Haag.

Loo, P.J.E. van de, G.W.M. Ramaekers, R.K.W. van der Velden (1992b), De arbeidsmarktpositie van afgestudeerden van het hoger technisch onderwijs 1991, HBO-Raad, Den Haag.

Loo, P.J.E. van de, G.W.M. Ramaekers, R.K.W. van der Velden (1992c), De arbeidsmarktpositie van afgestudeerden van het hoger economisch onderwijs 1991, HBO-Raad, Den Haag.

Loo, P.J.E. van de, G.W.M. Ramaekers, R.K.W. van der Velden (1992d), De arbeidsmarktpositie van afgestudeerden van het hoger gezondheidszorgonderwijs 1991, HBO-Raad, Den Haag.

Loo, P.J.E. van de, G.W.M. Ramaekers, R.K.W. van der Velden (1992e), De arbeidsmarktpositie van afgestudeerden van het hoger sociaal-agogisch onderwijs 1991, HBO-Raad, Den Haag.

Loo, P.J.E. van de, G.W.M. Ramaekers, R.K.W. van der Velden (1992f), De arbeidsmarktpositie van afgestudeerden van het kunstonderwijs 1991, HBO-Raad, Den Haag.

Loo, P.J.E. van de, R.K.W. van der Velden, M.H. Wieling (1993), De arbeidsmarktpositie van afgestudeerden van het hoger beroepsonderwijs: HBO-Monitor 1992, Voorlichtingsdienst HBORaad, Den Haag.

Ministerie van Onderwijs en Wetenschappen en Ministerie van Economische Zaken (1991), TWIN Technologie en Wetenschapsindicatoren, Zoetermeer, Den Haag.

Ministerie van Sociale Zaken en Werkgelegenheid (1988), Schoolverlatersbrief 1988, Directoraat-Generaal voor de Arbeidsvoorziening, Rijswijk.

Nieuwland, R.K.M., A. de Grip (1993), Gebruikersonderzoek ROA-rapport 'De arbeidsmarkt naar opleiding en beroep', ROA-W-1993/2, Maastricht.

ROA (1992a), De arbeidsmarkt naar opleiding en beroep tot 1994, ROA-R-1992/1, Maastricht.

ROA (1992b), Statistische bijlage: De arbeidsmarkt naar opleiding en beroep tot 1994, Actualisering 1992, ROA-R-1992/8B, Maastricht.

ROA (1993a), De arbeidsmarkt naar opleiding en beroep tot 1998, ROA-R-1993/10, Maastricht.

ROA (1993b), Statistische bijlage: De arbeidsmarkt naar opleiding en beroep tot 1998, ROA-R1993/10B, Maastricht.

Sheldon, G. (1985), Die berufliche und geographische Flexibilität, Institüt für Berufsforschung der Bundesanstalt für Arbeit, Beitrage AB92, Nürnberg.

Teulings, C.N., W.V. Webbink (1990), De bepaling van de arbeidsmarktrelevantie van opleidingen, SEO, Amsterdam. 
Tweede Kamer der Staten Generaal (1993), Voortijdig schoolverlaten, vergaderjaar 1992-1993, 22 994, nr.1, SDU-Uitgeverij, 's-Gravenhage.

Valk, J. van der, P. Berkhout (1992), De positie van schoolverlaters op de arbeidsmarkt, Supplement bij de sociaal-economische maandstatistiek, CBS, jaargang 1992, no. 3.

Velden, R.K.W. van der, L. Borghans (1993), Competition on the Labour Market: An Analysis of the Position of Types of Trainings, ROA-RM-1993/5E, Maastricht.

Warnken, J. (1986), Zur Entwicklung der 'internen' Anpassungsfähigheit der Berufe bis zum Jahre 2000: Projektionen unter den Annahmen der Wachstumsszenarien der Prognos-Studie, Mitteilungen aus der Arbeitsmarkt und Berufsforschung, no. 1, p. 119-133.

Wieling, M.H. (1991), School-leavers: Schooling, Job Level and Wages, ROA-RM-1991/6E, Maastricht.

Wieling, M.H., R.J.P. Dekker, A. de Grip (1991), Landelijke en regionale werkloosheidsindicatoren 1991, ROA-R-1991/8, Maastricht.

Wieling, M.H., A. de Grip, R.K.W. van der Velden (1992), Indicatoren onderwijs-arbeidsmarkt technisch en economisch onderwijs (LBO en MBO), ROA-R-1992/4, Maastricht.

Wieling, M.H., A. de Grip, E.J.T.A. Willems (1990), Een systematische kwalitatieve typering van arbeidsmarktinformatie, ROA-W-1990/8, Maastricht.

Wieling, M.H., P.J.E. van de Loo, R.K.W. van der Velden (1993a), Waar komen onze schoolverlaters terecht? De uitstroom en bestemming van het schooljaar 1990/1991, LDC, Leeuwarden.

Wieling, M.H., P.J.E. van de Loo, R.K.W. van der Velden (1993b), Waar komen de schoolverlaters van het middelbaar technisch onderwijs terecht? De uitstroom en bestemming van het schooljaar 1990/1991, LDC, Leeuwarden.

Willems, E.J.T.A. (1993), De arbeidsmarkt voor technisch opgeleiden: Haalbaarheidsonderzoek, ROA-R-1993/12, Maastricht. 
$-66-$

\section{BIJLAGE I. ONDERSCHEIDEN OPLEIDINGSRICHTINGEN}

Overzicht van de te onderscheiden opleidingsrichtingen

$$
\text { Nr. schooltype richting }
$$

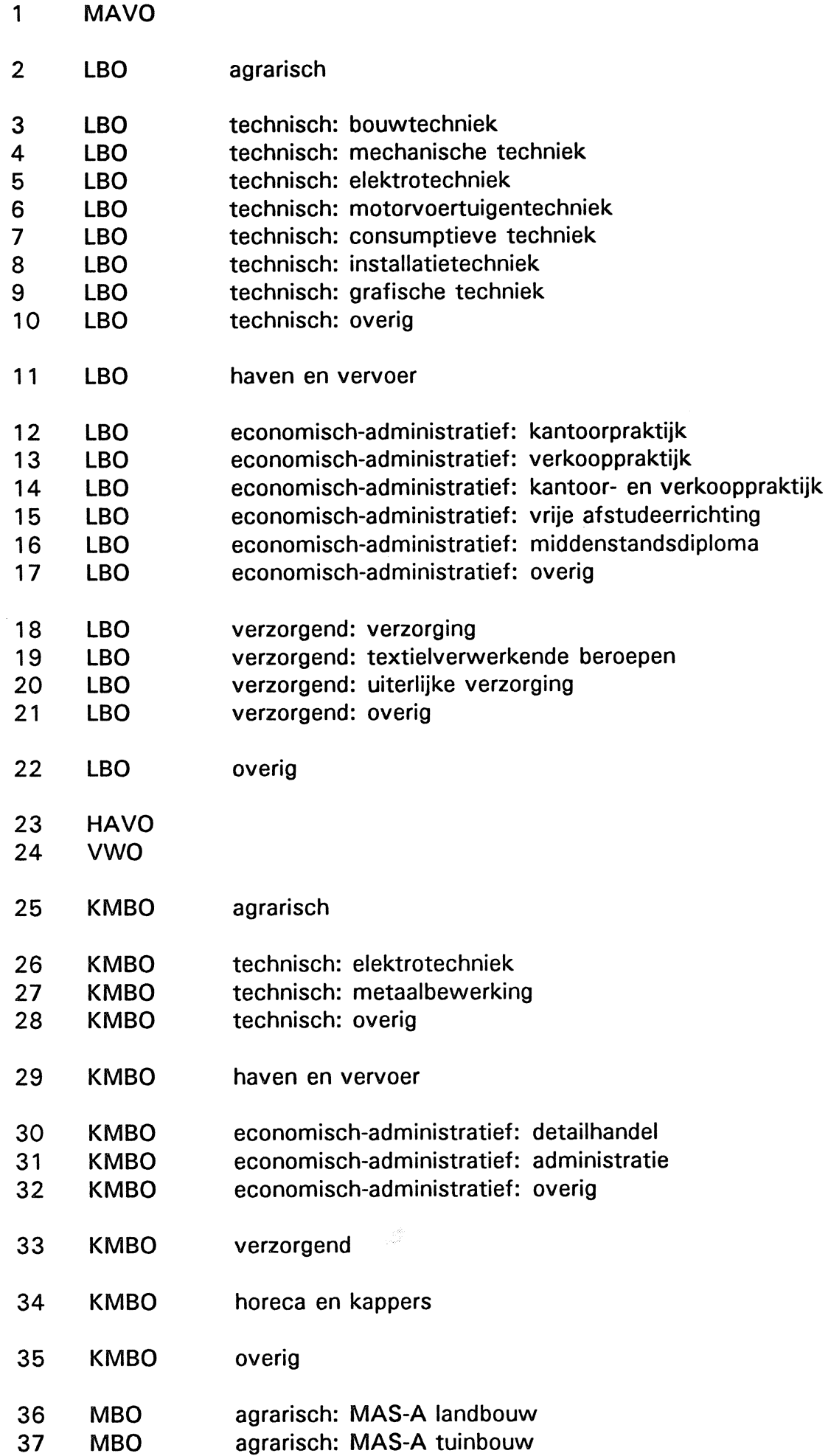




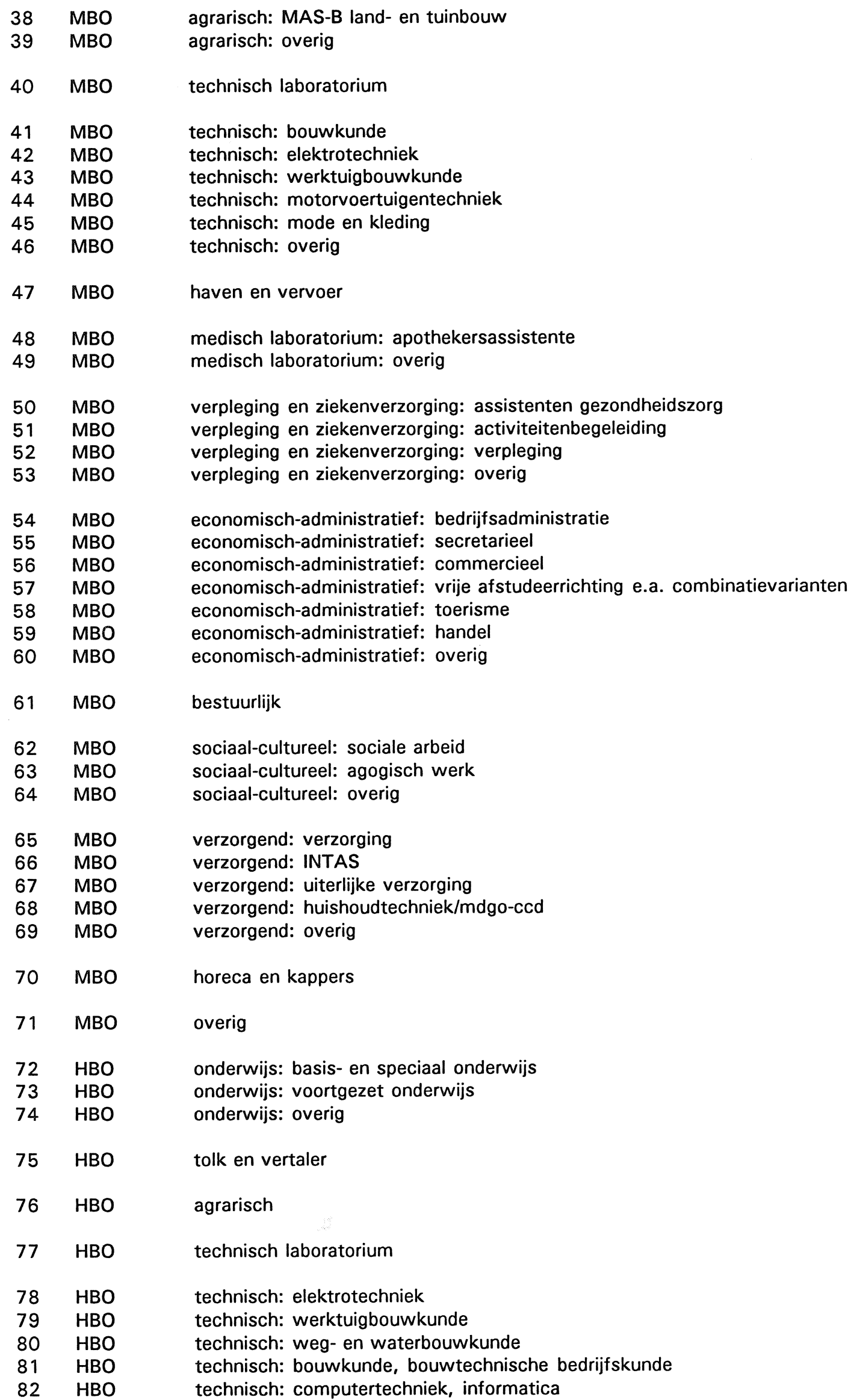




\begin{tabular}{|c|c|c|}
\hline 83 & $\mathrm{HBO}$ & technisch: overig \\
\hline 84 & $\mathrm{HBO}$ & haven en vervoer \\
\hline 85 & HBO & medisch laboratorium \\
\hline $\begin{array}{l}86 \\
87 \\
88 \\
89 \\
90 \\
91 \\
92\end{array}$ & $\begin{array}{l}\text { HBO } \\
\text { HBO } \\
\text { HBO } \\
\text { HBO } \\
\text { HBO } \\
\text { HBO } \\
\text { HBO }\end{array}$ & $\begin{array}{l}\text { verpleging en paramedisch: verpleging } \\
\text { verpleging en paramedisch: diëtetiek } \\
\text { verpleging en paramedisch: ergotherapie } \\
\text { verpleging en paramedisch: fysiotherapie } \\
\text { verpleging en paramedisch: logopedie } \\
\text { verpleging en paramedisch: creatieve therapie } \\
\text { verpleging en paramedisch: overig }\end{array}$ \\
\hline $\begin{array}{l}93 \\
94 \\
95 \\
96 \\
97 \\
98 \\
99\end{array}$ & $\begin{array}{l}\text { HBO } \\
\text { HBO } \\
\text { HBO } \\
\text { HBO } \\
\text { HBO } \\
\text { HBO } \\
\text { HBO }\end{array}$ & $\begin{array}{l}\text { economisch-administratief: bedrijfseconomie } \\
\text { economisch-administratief: (bedrijfs)informatica } \\
\text { economisch-administratief: commerciële economie } \\
\text { economisch-administratief: economisch-linguïstisch } \\
\text { economisch-administratief: accountancy } \\
\text { economisch-administratief: toeristisch en recreatief } \\
\text { economisch-administratief: overig }\end{array}$ \\
\hline 100 & $\mathrm{HBO}$ & technische bedrijfskunde \\
\hline 101 & HBO & bestuurlijk \\
\hline $\begin{array}{l}102 \\
103 \\
104 \\
105\end{array}$ & $\begin{array}{l}\text { HBO } \\
\text { HBO } \\
\text { HBO } \\
\text { HBO }\end{array}$ & $\begin{array}{l}\text { sociaal-cultureel: personeelswerk } \\
\text { sociaal-cultureel: maatschappelijk, inrichtings- en welzijnswerk } \\
\text { sociaal-cultureel: journalistiek, bibliotheek en documentaire informatie } \\
\text { sociaal-cultureel: overig }\end{array}$ \\
\hline 106 & $\mathrm{HBO}$ & verzorgend \\
\hline 107 & HBO & horeca \\
\hline 108 & $\mathrm{HBO}$ & kunst \\
\hline 109 & $\mathrm{HBO}$ & overig \\
\hline
\end{tabular}

Bron: RUBS 1992/HBO-Monitor 1991/ROA 


\section{BIJLAGE II. AANVULLENDE TABELLEN}

Tabel 1. Belangrijkste beroepsgroepen per opleidingsrichting (gediplomeerde schoolverlaters)

$\%$

LBO technisch: bouwtechniek

Timmerman

Metselaar e.d.

Huisschilder, constructieschilder

Meubelmaker (niet machinaal)

LBO technisch: mechanische techniek

Constructiewerker e.d.

Loodgieter, verwarmingsmonteur e.d.

Lasser, brander, snijder e.d.

Machinereparateur, onderhoudsmonteur

Chauffeur, trambestuurder

Auto-, motorrijwiel-, bromfietsmonteur

Plaatwerker e.d.

Lader, losser, magazijnknecht e.d.

Machinebankwerker-monteur

LBO technisch: elektrotechniek

Elektricien (aanleg/reparatie)

Winkelbediende, verkoper

Elektromonteur (machines/apparaten)

LBO technisch: motorvoertuigentechniek

Auto-, motorrijwiel-, bromfietsmonteur Machinereparateur, onderhoudsmonteur Chauffeur, trambestuurder

Lader, losser, magazijnknecht e.d.

LBO technisch: consumptieve techniek

Kok, keukenassistente

Bakker, chocolade-, suikerbewerker e.d.

Kelner, serveerster, buffetbediende e.d.

LBO technisch: installatietechniek

Loodgieter, verwarmingsmonteur e.d.

LBO technisch: grafische techniek

Drukker neg

Hand-, machinezetter

Boekhouder, kassier, lokettist

Boekbinder e.d.

Lader, losser, magazijnknecht e.d.

Repro-fotograaf, retoucheur, kopiist e.d. 
LBO technisch: overig

Winkelbediende, verkoper

Kapper, schoonheidsspecialiste e.d.

Boekhouder, kassier, lokettist

KMBO technisch: elektrotechniek

Elektricien (aanleg/reparatie)

Elektromonteur (machines/apparaten)

Winkelbediende, verkoper

Elektronicamonteur (bouw/installatie)

Employé magazijn, goederenexpeditie e.d.

KMBO technisch: metaalbewerking

Constructiewerker e.d.

Machinereparateur, onderhoudsmonteur

Machinebankwerker-monteur

Lasser, brander, snijder e.d.

Loodgieter, verwarmingsmonteur e.d.

Plaatwerker e.d.

Lader, losser, magazijnknecht e.d.

KMBO technisch: overig

Timmerman

Auto-, motorrijwiel-, bromfietsmonteur

Drukker neg

Winkelbediende, verkoper

Loodgieter, verwarmingsmonteur e.d.

Bakker, chocolade-, suikerbewerker e.d.

Elektricien (aanleg/reparatie)

MBO technisch laboratorium

Chemisch, fysisch analist, geologisch assistent e.d. 66

Botanisch-, medisch analist e.d.

MBO technisch: bouwkunde

Bouwkundig, technisch tekenaar e.d.

Bouwkundig technicus (middelbaar)

Timmerman

Werkmeester, hoofd produktie-afdeling

MBO technisch: elektrotechniek

Elektricien (aanleg/reparatie)

Bouwkundig, technisch tekenaar e.d.

Elektronicamonteur (bouw/installatie)

Elektromonteur (machines/apparaten)

Winkelbediende, verkoper

MBO technisch: werktuigbouwkunde

Bouwkundig, technisch tekenaar e.d. 
MBO technisch: motorvoertuigentechniek

Auto-, motorrijwiel-, bromfietsmonteur

Elektricien (aanleg/reparatie)

Bouwkundig, technisch tekenaar e.d.

MBO technisch: mode en kleding

Winkelbediende, verkoper

MBO technisch: overig

Winkelbediende, verkoper

Goud-, zilversmid, diamantbewerker e.d.

Bouwkundig, technisch tekenaar e.d.

Meubelmaker (niet machinaal)

HBO technisch laboratorium

Chemisch, fysisch analist, geologisch assistent e.d.

Botanisch-, medisch analist e.d.

Chemisch technoloog (hoger)

HBO technisch: elektrotechniek

Elektrotechnicus (hoger)

Automatiseringsdeskundige e.d.

Programmeur, systeembeheerder e.d.

HBO technisch: werktuigbouwkunde

Werktuig(bouw)kundige neg (hoger)

Bedrijfskundige e.d.

Werktuig(bouw)kundige e.d. (middelbaar)

Bouwkundig, technisch tekenaar e.d.

Automatiseringsdeskundige e.d.

HBO technisch: weg- en waterbouwkunde

Bouwkundige (hoger) 58

Bouwkundig technicus (middelbaar)

Bouwkundig, technisch tekenaar e.d.

HBO technisch: bouwkunde, bouwtechnische bedrijfskunde

Bouwkundige (hoger)

Bouwkundig, technisch tekenaar e.d.

Bouwkundig technicus (middelbaar)

HBO technisch: computertechniek, informatica

Automatiseringsdeskundige e.d. 
HBO technisch: overig

Chemisch technoloog (hoger)

Technicus specialisatie neg (hoger)

Werktuig(bouw)kundige neg (hoger)

Bedrijfskundige e.d.

Elektrotechnicus (hoger)

Automatiseringsdeskundige e.d.

HBO technisch: technische bedrijfskunde

Automatiseringsdeskundige e.d.

Bedrijfskundige e.d.

Econoom

Produktieplanner, werkvoorbereider e.d.

Algemeen bedrijfsleider

Bron: RUBS 1992/HBO-Monitor 1991/ROA 
Tabel 2. Belangrijkste bedrijfsklassen per opleidingsrichting (gediplomeerde schoolverlaters)

$\%$

\section{LBO technisch: bouwtechniek}

Bouwnijverheid

Hout-, meubelindustrie (excl. metaal)

Detailhandel

\section{LBO technisch: mechanische techniek}

Metaalproduktenindustrie

Bouwinstallatiebedrijf

Machine-industrie

Reparatiebedrijf gebruiksgoederen

Transportmiddelenindustrie

Detailhandel

Wegvervoer

Land-, tuinbouw

Bouwnijverheid

LBO technisch: elektrotechniek

Bouwinstallatiebedrijf

Detailhandel

Elektrotechnische industrie

Bouwnijverheid

\section{LBO technisch: motorvoertuigentechniek}

Reparatiebedrijf gebruiksgoederen

Wegvervoer

Detailhandel

Groothandel

LBO technisch: consumptieve techniek

Hotel, restaurant, café e.d.

\section{LBO technisch: installatietechniek}

Bouwinstallatiebedrijf

Bouwnijverheid

Detailhandel

Zeevaart

LBO technisch: grafische techniek

Grafische industrie, uitgeverij

Zakelijke dienstverlening

Detailhandel

Overheid, defensie, sociale verzekering 
LBO technisch: overig

Detailhandel

Overig dienstverlenend bedrijf

Voedings-, genotmiddelenindustrie

Machine-industrie

Hotel, restaurant, café e.d.

KMBO technisch: elektrotechniek

Bouwinstallatiebedrijf

Elektrotechnische industrie

Detailhandel

Bouwnijverheid

Machine-industrie

Groothandel

Communicatiebedrijf

KMBO technisch: metaalbewerking

Metaalproduktenindustrie

Machine-industrie

Bouwnijverheid

Transportmiddelenindustrie

KMBO technisch: overig

Bouwnijverheid

Detailhandel

Grafische industrie, uitgeverij

Bouwinstallatiebedrijf

Reparatiebedrijf gebruiksgoederen

MBO technisch laboratorium

Chemische industrie 25

Sociale organisatie $\quad 17$

Voedings-, genotmiddelenindustrie $\quad 13$

Gezondheids-, veterinaire dienst $\quad 8$

Overheid, defensie, sociale verzekering $\quad 7$

$\begin{array}{ll}\text { Detailhandel } & 7\end{array}$

Openbaar nutsbedrijf

MBO technisch: bouwkunde

Bouwnijverheid $\quad 49$

$\begin{array}{ll}\text { Zakelijke dienstverlening } & 21\end{array}$

MBO technisch: elektrotechniek

Bouwinstallatiebedrijf 26

Zakelijke dienstverlening $\quad 11$

Groothandel $\quad 9$

Detailhandel $\quad 8$

Elektrotechnische industrie $\quad 8$

Communicatiebedrijf $\quad 6$

Machine-industrie $\quad 5$ 
MBO technisch: werktuigbouwkunde

Machine-industrie

Metaalproduktenindustrie

Zakelijke dienstverlening

Bouwinstallatiebedrijf

Groothandel

MBO technisch: motorvoertuigentechniek

Reparatiebedrijf gebruiksgoederen $\quad 38$

Detailhandel

Machine-industrie

Wegvervoer

MBO technisch: mode en kleding

Detailhandel

Zakelijke dienstverlening

Kledingindustrie

Grafische industrie, uitgeverij

Groothandel

MBO technisch: overig

Detailhandel

Hout-, meubelindustrie (excl. metaal)

Zakelijke dienstverlening

Bouwnijverheid

Groothandel

HBO technisch laboratorium

Sociale organisatie $\quad 29$

Chemische industrie $\quad 16$

Gezondheids-, veterinaire dienst $\quad 15$

Onderwijs 14

$\begin{array}{lr}\text { Overheid, defensie, sociale verzekering } & 6\end{array}$

HBO technisch: elektrotechniek

Zakelijke dienstverlening $\quad 34$

$\begin{array}{lr}\text { Groothandel } & 9\end{array}$

$\begin{array}{lr}\text { Elektrotechnische industrie } & 8\end{array}$

$\begin{array}{ll}\text { Machine-industrie } & 8\end{array}$

$\begin{array}{ll}\text { Overheid, defensie, sociale verzekering } & 7\end{array}$

Bouwinstallatiebedrijf $\quad 5$

Communicatiebedrijf $\quad 5$

HBO technisch: werktuigbouwkunde

Zakelijke dienstverlening

Machine-industrie $\quad 21$

Metaalproduktenindustrie $\quad 8$

$\begin{array}{ll}\text { Groothandel } & 5\end{array}$

HBO technisch: weg-en waterbouwkunde

$\begin{array}{ll}\text { Bouwnijverheid } & 35\end{array}$

Zakelijke dienstverlening

Overheid, defensie, sociale verzekering $\quad 23$ 
HBO technisch: bouwkunde, bouwtechnische bedrijfskunde

Zakelijke dienstverlening

Overheid, defensie, sociale verzekering

HBO technisch: computertechniek, informatica

Zakelijke dienstverlening

Overheid, defensie, sociale verzekering

Metaalproduktenindustrie

Sociale organisatie

Grafische industrie, uitgeverij

Elektrotechnische industrie

HBO technisch: overig

Zakelijke dienstverlening

Chemische industrie

Machine-industrie

Transportmiddelenindustrie

Overheid, defensie, sociale verzekering

6

Sociale organisatie

HBO technisch: technische bedrijfskunde

Zakelijke dienstverlening

Groothandel

Machine-industrie

Chemische industrie 
Tabel 3. Belangrijkste opleidingsrichtingen waarmee schoolverlaters van de onderscheiden opleidingsrichtingen concurreren (gediplomeerde schoolverlaters)

concurrentie-index

LBO technisch: bouwtechniek

KMBO technisch: overig

LBO technisch: mechanische techniek

KMBO technisch: metaalbewerking

LBO technisch: installatietechniek

LBO technisch: elektrotechniek

MBO technisch: elektrotechniek

KMBO technisch: elektrotechniek

LBO technisch: motorvoertuigentechniek

KMBO technisch: overig

MBO technisch: motorvoertuigentechniek

LBO technisch: consumptieve techniek

KMBO horeca en kappers

LBO technisch: installatietechniek

LBO technisch: mechanische techniek

LBO technisch: overig

LBO agrarische

KMBO economisch-administratief: administratie

$M B O$ verzorgend: uiterlijke verzorging

0,45

$\mathrm{KMBO}$ verzorgend

0,49

MBO technisch: overig

LBO economisch-administratief: overig

0,55

LBO verzorgend: uiterlijke verzorging

0,57

VWO

0,69

LBO verzorgend: overig

0,74

HAVO

0,75

LBO economisch-administratief: kantoorpraktijk

0,76

LBO economisch-administratief: vrije afstudeerrichting $\quad 0,86$

LBO verzorgend: verzorging

0,88

MBO economisch-administratief: handel $\quad 0,91$

MBO technisch: mode en kleding

LBO economisch-administratief: kantoor- en verkooppraktijk

0,93

KMBO economisch-administratief: detailhandel

0,93

MAVO

0,95

LBO economisch-administratief: verkooppraktijk

0,95

LBO economisch-administratief: middenstandsdiploma

0,95 
KMBO technisch: elektrotechniek

MBO technisch: elektrotechniek

KMBO technisch: metaalbewerking

MBO technisch: werktuigbouwkunde

KMBO technisch: overig

LBO technisch: motorvoertuigentechniek

MBO technisch: motorvoertuigentechniek

LBO technisch: bouwkunde

MBO technisch laboratorium

HBO technisch laboratorium

MBO technisch: bouwkunde

MBO technisch: overig

HBO technisch: bouwkunde

MBO technisch: werktuigbouwkunde

MBO technisch: elektrotechniek

MBO technisch: werktuigbouwkunde

LBO technisch: elektrotechniek

KMBO technisch: elektrotechniek

MBO technisch: werktuigbouwkunde

HBO technisch: werktuigbouwkunde

HBO technisch: bouwkunde

KMBO technisch: metaalbewerking

0,43

MBO technisch: overig

0,45

MBO technisch: elektrotechniek

0,51

MBO technisch: bouwkunde

0,68

MBO technisch: motorvoertuigentechniek

KMBO technisch: overig 


\section{MBO technisch: mode en kleding}

LBO agrarisch

KMBO economisch-administratief: administratie

MBO technisch: overig

LBO economisch-administratief: overig

LBO verzorgend: overig

HAVO

LBO economisch-administratief: kantoorpraktijk

LBO verzorgend: verzorging

LBO economisch-administratief: vrije afstudeerrichting

MAVO

LBO technisch: overig

LBO economisch-administratief: verkooppraktijk

LBO economisch-administratief: kantoor- en verkooppraktijk

LBO economisch-administratief: middenstandsdiploma

MBO economisch-administratief: handel

KMBO economisch-administratief: detailhandel

MBO technisch: overig

HAVO

LBO economisch-administratief: kantoorpraktijk $\quad 0,45$

MBO technisch: bouwkunde $\quad 0,45$

MBO technisch: werktuigbouwkunde $\quad 0,45$

$\begin{array}{ll}\text { LBO verzorgend: verzorging } & 0,47\end{array}$

LBO economisch-administratief: vrije afstudeerrichting $\quad 0,48$

MAVO

LBO technisch: overig

LBO economisch-administratief: verkooppraktijk

LBO economisch-administratief: kantoor- en verkooppraktijk $\quad 0,57$

LBO economisch-administratief: middenstandsdiploma $\quad 0,57$

$\begin{array}{ll}\text { KMBO economisch-administratief: detailhandel } & 0,57\end{array}$

$\begin{array}{ll}\text { MBO economisch-administratief: handel } & 0,57\end{array}$

$\begin{array}{ll}\text { MBO technisch: mode en kleding } & 0,59\end{array}$

HBO technisch laboratorium

$\begin{array}{ll}\text { MBO medisch laboratorium: overig } & 0,70\end{array}$

$\begin{array}{ll}\text { HBO medisch laboratorium } & 0,71\end{array}$

$\begin{array}{lr}\text { MBO technisch laboratorium } & 0,82\end{array}$

HBO technisch: elektrotechniek

$\begin{array}{ll}\text { HBO technische bedrijfskunde } & 0,42\end{array}$

$\begin{array}{ll}\text { HBO technisch: computertechniek, informatica } & 0,47\end{array}$

$\begin{array}{ll}\text { HBO economisch-administratief: (bedrijfs)informatica } & 0,52\end{array}$

HBO technisch: werktuigbouwkunde

$\begin{array}{ll}\text { MBO technisch: werktuigbouwkunde } & 0,41\end{array}$

$\begin{array}{ll}\text { HBO haven en vervoer } & 0,44\end{array}$

$\begin{array}{lr}\text { HBO technische bedrijfskunde } & 0,48\end{array}$

$\begin{array}{lr}\text { HBO technisch: overig } & 0,57\end{array}$

HBO technisch: weg-en waterbouwkunde

HBO technisch: bouwkunde 
$-80-$

HBO technisch: bouwkunde, bouwtechnische bedrijfskunde

MBO technisch: werktuigbouwkunde

MBO technisch: bouwkunde

0,49

HBO technisch: weg-en waterbouwkunde

HBO technisch: computertechniek, informatica

HBO technisch: elektrotechniek

HBO technische bedrijfskunde

0,65

HBO economisch-administratief: (bedrijfs)informatica

0,99

HBO technisch: overig

HBO technische bedrijfskunde

HBO technisch: werktuigbouwkunde

HBO technisch: technische bedrijfskunde

HBO technisch: elektrotechniek

HBO technisch: werktuigbouwkunde

HBO technisch: overig

0,49

HBO technisch: computertechniek, informatica

0,65

HBO economisch-administratief: (bedrijfs)informatica

0,68

Bron: RUBS 1992/HBO-Monitor 1991/ROA 